\begin{abstract}
UNIVERSIDADE DE SÃO PAULO
FACULDADE DE MEDICINA DE RIBEIRÃO PRETO

DEPARTAMENTO DE BIOQUÍMICA E IMUNOLOGIA
\end{abstract}

Ana Carolina Guerta Salina

Ativação de Macrófagos M1/M2 pela eferocitose de células apoptóticas infectadas

Ribeirão Preto

2020 


\author{
UNIVERSIDADE DE SÃO PAULO \\ FACULDADE DE MEDICINA DE RIBEIRÃO PRETO \\ DEPARTAMENTO DE BIOQUÍMICA E IMUNOLOGIA
}

Ana Carolina Guerta Salina

\title{
Ativação de Macrófagos M1/M2 pela eferocitose de células apoptóticas infectadas
}

\author{
Versão Corrigida
}

Tese apresentada à Faculdade de Medicina de

Ribeirão Preto da Universidade de São Paulo para obtenção do título de Doutora em Ciências

Área de Concentração: Imunologia Básica e Aplicada Orientadora: Prof ${ }^{\mathrm{a}}$. Dr ${ }^{\mathrm{a}}$. Alexandra Ivo de Medeiros Co-orientador: Prof. Dr Carlos Henrique Serezani

Ribeirão Preto 
Autorizo a reprodução e divulgação total ou parcial deste trabalho, por qualquer meio convencional ou eletrônico, para fins de estudo e pesquisa, desde que citada a fonte.

Salina, Ana Carolina Guerta

Ativação de Macrófagos M1/M2 pela eferocitose de células apoptóticas infectadas. Ribeirão Preto, 2020.

155 p: il.; $30 \mathrm{~cm}$

Tese de Doutorado, apresentada à Faculdade de Medicina de Ribeirão Preto/USP. Área de concentração: Imunologia.

Orientador: Medeiros, Alexanda Ivo.

1. Macrófagos M1/M2. 2. Streptococcus pneumoniae. 3. Klebsiella pneumoniae. 4. Células Apoptóticas. 


\section{Folha de Aprovação}

\section{Ana Carolina Guerta Salina}

Ativação de Macrófagos M1/M2 pela eferocitose de células apoptóticas infectadas.

Tese apresentada ao Programa de Pós-Graduação em Imunologia Básica e Aplicada da Faculdade de Medicina de Ribeirão Preto da Universidade de São Paulo para obtenção do título de Doutor em Ciências. Área de concentração: Imunologia Básica e Aplicada.

\section{Aprovado em:}

Banca examinadora

Prof(a) $\operatorname{Dr}(a)$ :

Instituição:

Julgamento:

Assinatura:

$\operatorname{Prof}(a) \operatorname{Dr}(a)$ :

Instituição:

Julgamento:

Assinatura:

Prof(a) $\operatorname{Dr}(a)$ :

Instituição:

Julgamento:

Assinatura: 
Essa tese recebeu fomento da Fundação de Amparo à Pesquisa do Estado de São Paulo (FAPESP), processos 2017/04786-0, 2018/01622-9 e 2017/19870-6, Conselho Nacional de Desenvolvimento Científico e Tecnológico (CNPq), processo 141569/2016-6 e 307109/2016-0 e CAPES. 
Aos meus pais, Maria e Fernando, por acreditarem e investirem em minha formação.

Essa vitória é mérito de vocês! 


\section{AGRADECIMENTOS}

À Ana do passado, por todas as noites mal dormidas, por todos os finais de semanas dentro do laboratório, pelos momentos em família abdicados para que essa tese fosse concluída, e, principalmente, por não ter desistido quando toda a vontade era tê-lo feito.

Aos meus pais, pela educação, amor, carinho, apoio e confiança em todos esses longos anos de estudo.

À professora Alexandra pela oportunidade acadêmica, conhecimento adquirido e convivência ao longo desses anos todos.

Ao professor Henrique por me mostrar que o mundo que eu sempre sonhei existe.

Aos colegas de laboratório, pelo convívio e ajuda em todos os momentos, sejam eles de resultados significativos ou de desespero geral.

Aos funcionários e servidores da FCF-UNESP e FMRP-USP por todo o auxílio na execução desse trabalho.

À FCF-UNESP, FMRP-USP, FAPESP (2017/04786-0, 2018/01622-9 e 2017/19870-6), CAPES e CNPq (141569/2016-6 e 307109/2016-0), pelo apoio financeiro $e$ institucional para a realização desse trabalho. 


\section{LISTA DE ABREVIATURAS}

AC - Células apoptóticas

AC-Kp - Células apoptóticas infectadas com Klebsiella pneumoniae

AC-Sp - Células apoptóticas infectadas com Streptococcus pneumoniae

AMP - Adenosine monophosphate

ASC - Apoptosis associated speck-like containing a CARD domain

ATP - Adenosine triphosphate

BAI 1 - Brain specific angiogenesis inhibitor 1

BMDM - Bone marrow derived macrophages

casp11KO - camundongo deficiente para caspase 11

CCL2 - Chemokine (C-C motif ligand 2)

CD - Células dendríticas

CX3CL1 - Chemokine (C-X3-C motif) ligand 1

DAMPs - Damage Associated Molecular Pattern

DGCR8 - Di George Critical Region 8

DMEM - Dulbecco's modified Eagle medium

DMSO - Dimetilsufóxido

DT - Diphtheria toxin

DTR - Diphtheria toxin receptor

GM-CSF - Granulocyte-Macrophage Colony-Stimulating Factor

IL - Interleucin

IRAK - IL-1 receptor-associated kinase

Kp - Klebsiella pneumoniae

LPC - Lysophosphatidylcholine

LPS - Lipopolysaccharide

LTA - Lipoteichoic acid

LXR - liver X receptor

MAL - MyD88 adaptor-like protein

MCP-1 - Monocyte chemoattractant protein 1

MerKT - MER tyrosine kinase 
MFI - Média da intensidade de fluorescência

MHC - Major histocompatibility complex

miRNAs - MicroRNAs

MOI - Multiplicidade de infecção

MRSA - Methicillin-resistant Staphylococcus aureus

MyD88 - Myeloid differentiation factor 88

NO - Óxido nitríco

NOD - Nucleotide-binding and oligomerization domain

oxPAPC - Oxidized phospholipids derived from 1-palmitoyl-2-arachidonyl-sn-

glycero-3-phosphorylcholine

PAF - Platelet-activating factor

PAMPs - Pathogen Associated Molecular Patterns

$\mathrm{PGE}_{2}-$ Prostaglandin $E_{2}$

PMA - Phorbol 12-myristate 13-acetate

PRR - Pattern recognition receptors

PS - Phosphatidylserine

PS-OX - Oxidized phosphatidylserine

RAGE - Receptor for advanced glycationend products

RANTES - Regulated on Activation, Normal T Cell Expressed and Secreted

RIP2 - Receptor-interacting protein 2

RLR - RIG-I-like receptors

SFB - Soro fetal bovino

Sp - Streptococcus pneumoniae

S1P - Sphingosine-1-phosphate

TGF- $\beta$ - Transforming Growth Factor Beta

TIM - T cell immunoglobulin mucin domain

TIRAP - TIR-associated protein

TLRs - Toll Like Receptors

TLR2KO - Camundongo deficientes para TLR2

TLR4KO - Camundongo deficientes para TLR4

TNF- $\alpha$ - Tumor Necrosis Factor Alfa 
TRAM - TRIF-related adaptor molecule

TRIF - TIR domain-containing adaptor protein including interferon

TSA - tryptic soy agar

TSB - tryptic soy broth

UFC - Unidades formadoras de colônias

UTP - Uridinetriphosphate

UVC - Radiação ultravioleta C

WT - Animais selvagens

7-AAD - 7-aminoactinomycin D 


\section{SUMÁRIO}

CAPÍTULO 1.

1.1. Reconhecimento de células apoptóticas e o impacto nas células do sistema imune ........ 1

1.2. Reconhecimento de patógenos e ativação de células da imunidade inata .......................... 4

1.3. Ativação de macrófagos M1/M2 no contexto de eferocitose ..........................................

1.4. Vias de sinalização intracelular envolvidas na ativação de macrófagos M1/M2 ............... 9

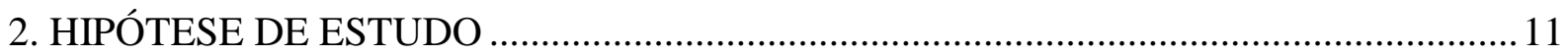

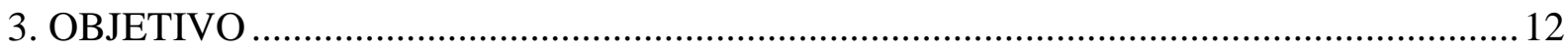

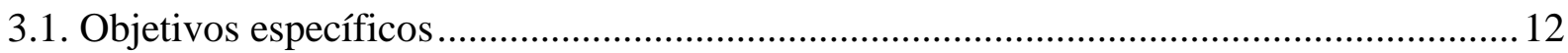

4. MATERIAL E MÉTODOS .................................................................................. 13

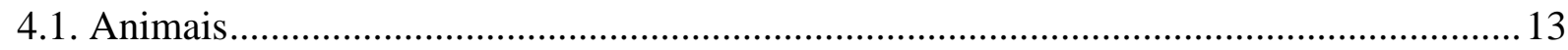

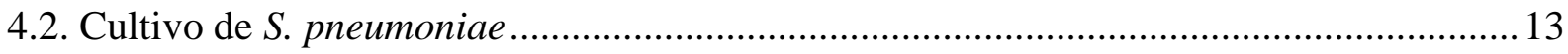

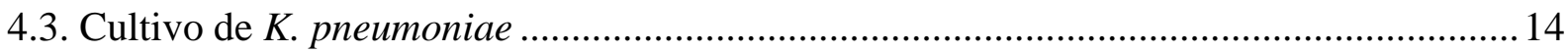

4.4. Obtenção de Células Apoptóticas Infectadas oriundas da linhagem celular

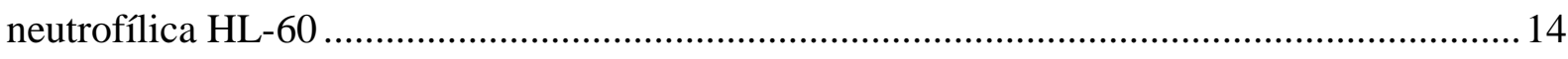

4.5. Diferenciação de macrófagos M0 a partir de precursores de Medula Óssea..................... 15

4.6. Determinação da eferocitose de células apoptóticas ..................................................... 15

4.7. Polarização de macrófagos M0 na presença de diferentes fontes de células

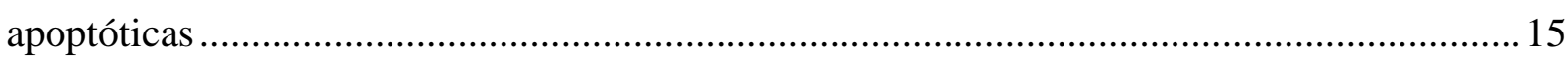

4.8. Avaliação das vias de sinalizações envolvidas na polarização de macrófagos ................. 15

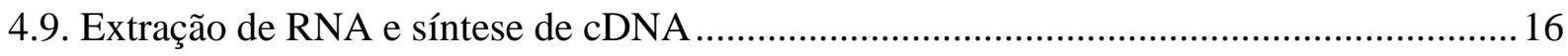

4.10. Análise relativa dos níveis de mRNA por PCR em tempo real (qPCR)........................ 16

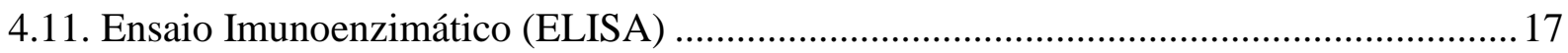

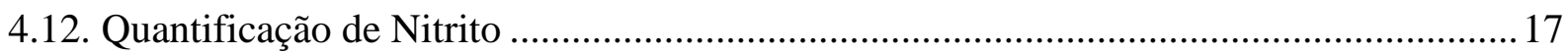

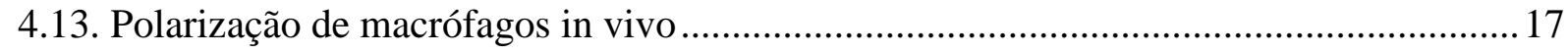


4.14. Análise estatística

5. RESULTADOS

5.1. Determinação da porcentagem de neutrófilos-like infectados

5.2. Indução de apoptose celular em neutrófilos-like . 22

5.3. Avaliação da porcentagem de eferocitose de macrófagos M0 25

5.4. Perfil de ativação de macrófagos M0 após a eferocitose de células apoptóticas estéreis ou infectadas com S. pneumoniae ou K. pneumoniae

5.5. Participação de receptores do tipo Toll no perfil de ativação de macrófagos M0 após a eferocitose de células apoptóticas estéreis ou infectadas com S. pneumoniae ou $K$. pneumoniae.

5.6. Participação do fator de transcrição NF- $\kappa B$ no perfil de ativação de macrófagos $M 0$ após a eferocitose de células apoptóticas estéreis ou células apoptóticas infectadas com S. pneumoniae ou K. pneumoniae

5.7. Envolvimento dos fatores de transcrição STAT1 e STAT3 no perfil de ativação de macrófagos M0 após a eferocitose de células apoptóticas estéreis ou células apoptóticas infectadas com S. pneumoniae ou K. pneumoniae

5.8. Participação da via não canônica do inflamassoma no perfil de ativação de macrófagos M0 após a eferocitose de células apoptóticas estéreis ou infectadas com $S$. pneumoniae ou K. pneumoniae.

5.9. Efeito da instilação de células apoptóticas estéreis ou infectadas com S. pneumoniae

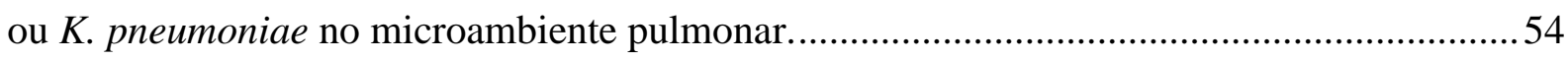

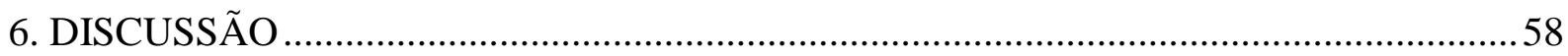

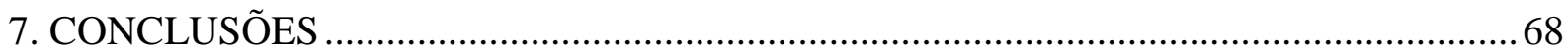

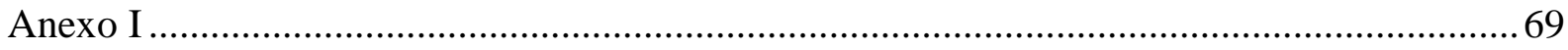

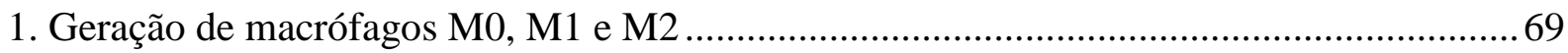

3. Determinação da concentração de CFSE utilizada para marcação bacteriana ......................73 
4. Perfil de ativação de macrófagos M0 após a cocultura com células viáveis ou células apoptóticas ou células necróticas.

5. Perfil de ativação de macrófagos M0 após a fagocitose de $S$. pneumoniae ou $K$. pneumoniae

CAPÍTULO 2.

1. INTRODUÇÃ

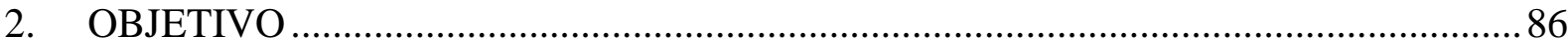

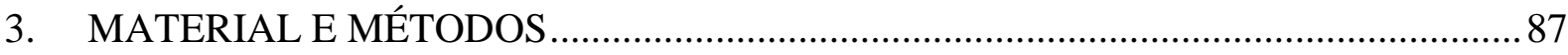

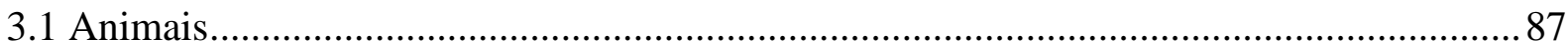

3.2. Cultivo de Staphylococcus aureus resistente à meticilina (MRSA) ................................ 87

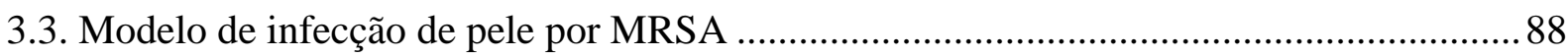

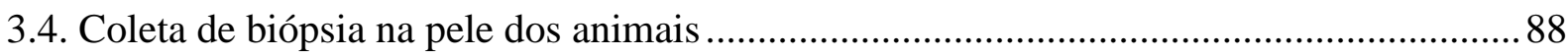

3.5. Determinação da carga bacteriana nas lesões de pele .................................................. 88

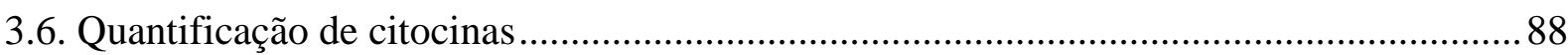

3.7. Extração de RNA, geração de cDNA e qRT-PCR ........................................................... 89

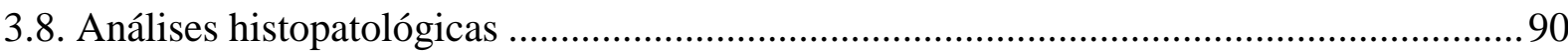

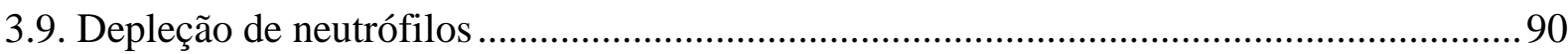

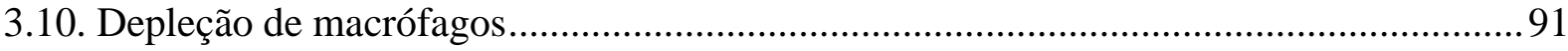

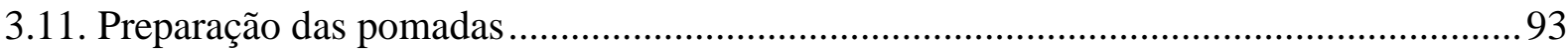

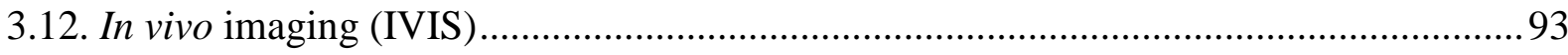

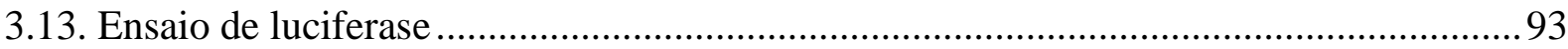

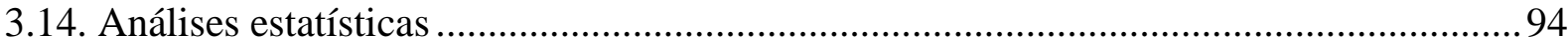

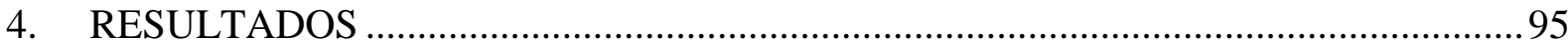

4.1. miR-21 é expresso durante a infecção de pele por $S$. aureus ………..............................95

4.2 A expressão de miR-21 prejudica a resposta imune do hospedeiro contra $S$. aureus ........97 
4.3 A inibição de miR-21 resulta na melhora das respostas contra S. aureus

4.4 A deficiência de miR-21 melhora a formação do abscesso durante a infecção de pele por S. aureus

4.5 miR-21 inibe a resolução da infecção por $S$. aureus cutânea via de MyD88 107

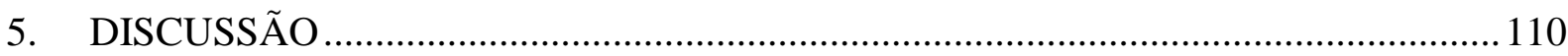

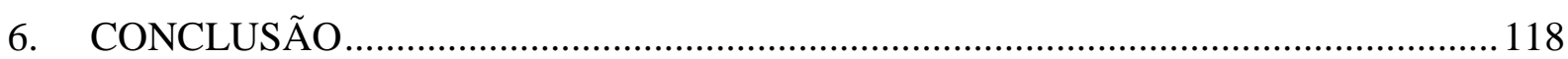

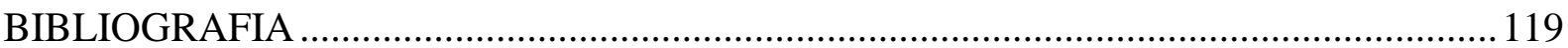




\section{LISTA DE TABELAS}

Tabela 1. Lista de primers utilizados para a fenotipagem dos macrófagos após a

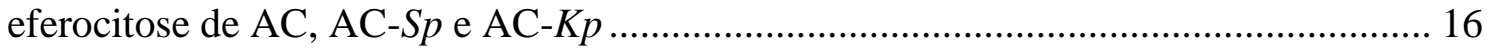

Tabela 2. Painel de beads magnéticas utilizadas no ensaio de Multiplex ...................... 89

Tabela 3. Primers utilizados para a análises das biópsias de pele ................................. 90 


\section{LISTA DE FIGURAS}

Figura 1. A eferocitose de diferentes fontes de células infectadas promove a polarização diferenciada de macrófagos M0.

Figura 2. Protocolo experimental in vivo de instilação de células apoptóticas infectadas.

Figura 3. Determinação da porcentagem de fagocitose dos neutrófilos-like cultivados com S. pneumoniae ou K. pneumoniae.

Figura 4. Perfil de morte celular dos neutrófilos-like infectados ou não infectados após $1 \mathrm{~mJ}$ de radiação UVC.

Figura 5. Porcentagem de eferocitose das diferentes fontes de células apoptóticas. 26

Figura 6. Perfil de expressão gênica e mediadores secretados por macrófagos após a eferocitose de AC, AC-Sp ou AC-Kp. 28

Figura 7. Perfil de expressão gênica e de mediadores secretados por macrófagos deficientes de TLR2 ou TLR4 após a eferocitose de células apoptóticas estéreis. 30 Figura 8. Perfil de expressão gênica e mediadores secretados por macrófagos deficientes de TLRs após a eferocitose de células apoptóticas infectadas com S. pneumoniae. 32 Figura 9. Perfil de expressão gênica e mediadores secretados por macrófagos deficientes de TLRs após a eferocitose de células apoptóticas infectadas com K. pneumoniae. ..... 34 Figura 10. Perfil de expressão gênica e mediadores secretados por macrófagos tratados com inibidor de NF- $\mathrm{KB}$ após a eferocitose de células apoptóticas estéreis. 36

Figura 11. Perfil de expressão gênica e mediadores secretados por macrófagos tratados com inibidor de NF-кB após a eferocitose de células apoptóticas infectadas com $S$. pneumoniae. 38

Figura 12. Perfil de expressão gênica e de mediadores secretados por macrófagos

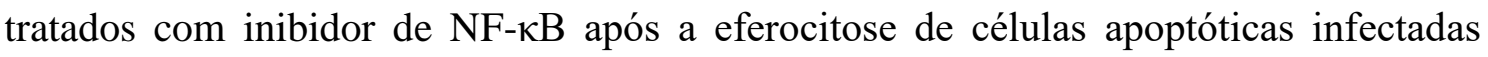
com K. pneumoniae. 
Figura 13. Perfil de expressão gênica e mediadores secretados por macrófagos tratados com inibidores de STAT após a eferocitose de células apoptóticas estéreis.

Figura 14. Perfil de expressão gênica e de mediadores secretados por macrófagos tratados com inibidores de STAT1 e STAT3 após a eferocitose de células apoptóticas infectadas com S. pneumoniae. 45

Figura 15. Perfil de expressão gênica e de mediadores secretados por macrófagos tratados com inibidores de STAT após a eferocitose de células apoptóticas infectadas com K. pneumoniae.

Figura 16. Perfil de expressão gênica e de mediadores secretados por macrófagos deficientes de caspase 11 após a eferocitose de células apoptóticas estéreis.

Figura 17. Perfil de expressão gênica de macrófagos deficientes de caspase 11 após a eferocitose de células apoptóticas infectadas com S. pneumoniae.

Figura 18. Perfil de expressão gênica e de mediadores secretados por macrófagos deficientes de caspase 11 após a eferocitose de células apoptóticas infectadas com K. pneumoniae.

Figura 19. Perfil de expressão gênica de células pulmonares após a eferocitose dos diferentes tipos de células apoptóticas.

Figura 20. Citocinas produzidas no pulmão dos animais que receberam células apoptóticas estéreis, células apoptóticas infectadas com S. pneumoniae ou células apoptóticas infectadas com $\mathrm{K}$. pneumoniae.

Figura 21. Análise da expressão de genes e mediadores secretados por macrófagos $\mathrm{M} 0 / \mathrm{M} 1 / \mathrm{M} 2$. 70

Figura 22. Apoptose basal de neutrófilos gerados a partir das células HL-60. 72

Figura 23. Marcação de Streptococcus pneumoniae com diferentes concentrações de CFSE.

Figura 24. Marcação de Klebsiella pneumoniae com diferentes concentrações de CFSE. 
Figura 25. Perfil de expressão gênica e de mediadores secretados por macrófagos cultivados na presença de células apoptóticas, células viáveis e células necróticas. ..... 78 Figura 26. Perfil de expressão gênica e de mediadores secretados por macrófagos M0

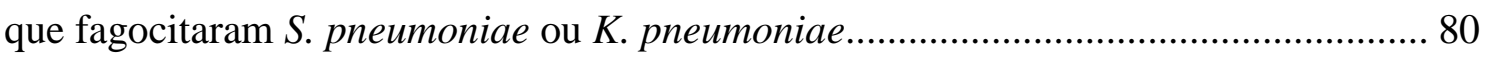

Figura 27. Protocolo de depleção de macrófagos em animais MMDTR ...................... 92 Figura 28. Macrófagos expressam miR-21 durante a infecção de pele por S. aureus.... 96 Figura 29. A inibição de miR-21 melhora a defesa do hospedeiro durante a infecção de pele por S. aureus 99

Figura 30. O tratamento cutâneo com antagomiR-21 resulta em uma eficiente eliminação bacteriana e diminuição da área de lesão durante a infecção por S. aureus. 101

Figura 31. A deficiência de miR-21 promove acúmulo de macrófagos na borda do abscesso. 103

Figura 32. A deficiência de miR-21 promove o aumento da espessura do abscesso e deposição de colágeno. 104

Figura 33. A infecção por S. aureus induz um perfil gênico semelhante em animais miR2 $1^{\Delta \text { myel }}$ e animais tratados com antagomir-21. 106

Figura 34. miR-21 inibe MyD88 durante a infecção por S. aureus. 109 
CAPítulo 1. 


\section{RESUMO}

\section{SALINA, ACG. Ativação de Macrófagos M1/M2 pela eferocitose de células}

apoptóticas infectadas. 2020. 155f. Tese de doutorado. Faculdade de Medicina de Ribeirão Preto - Universidade de São Paulo, Ribeirão Preto, 2020.

Durante os processos infecciosos há um intenso recrutamento de fagócitos, como neutrófilos e monócitos para o tecido afetado, na tentativa de conter a proliferação bacteriana. Estas células, após exercerem suas funções efetoras, entram em processo de morte celular, resultando em um intenso acúmulo de células apoptóticas infectadas no tecido. A fagocitose dessas células apoptóticas, denominada eferocitose, é um processo dinâmico e de fundamental importância para a homeostase dos tecidos impedindo dessa forma a necrose tecidual. Dentre esses os fagócitos, os macrófagos são importantes tanto na defesa contra microrganismos como na remoção destas células apoptóticas.

Existem ao menos duas populações de macrófagos que se diferem quanto ao estado de ativação e função imunológica. Os macrófagos M1 são pró-inflamatórios e especializados no combate às infecções, enquanto os macrófagos M2 são antiinflamatórios e estão relacionados ao reparo tecidual. Até o momento, pouco se sabe sobre o efeito da fagocitose de células apoptóticas infectadas na diferenciação destas subpopulações de macrófagos M1/M2. Nesse estudo demonstramos que a eferocitose de células apoptóticas infectadas por Streptococcus pneumoniae (AC-Sp) induz um perfil misto de polarização dependente das vias de sinalização desencadeadas pelos receptores

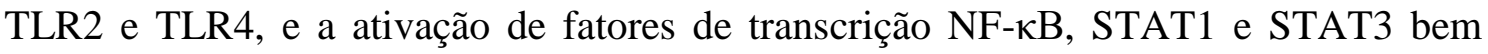
como caspase 11. Por outro lado, a fagocitose de células apoptóticas infectadas com Klebsiella pneumoniae (AC-Kp) induziu a ativação de macrófagos $\mathrm{M} 1$ via $\mathrm{NF}-\kappa \mathrm{B}$ e STAT1. A instilação de AC-Sp in vivo induz um microambiente menos inflamatório, enquanto a instilação de $\mathrm{AC}-K p$ resulta na produção tanto mediadores inflamatórios como anti-inflamatórios no microambiente pulmonar. Esse estudo contribui no entendimento de como a eferocitose de células apoptóticas infectadas por diferentes bactérias pode promover a ativação e diferenciação de macrófagos em um perfil M1/M2 e, por sua vez, exercer diferentes funções efetoras tanto na resolução da infecção como 
no restabelecimento da homeostase tecidual. Palavras-chave: Macrófagos M1/M2, eferocitose, Streptococcus pneumoniae, Klebsiella pneumoniae, células apoptóticas. 


\begin{abstract}
SALINA, ACG. M1/M2 macrophage activation by efferocytosis of infectedapoptotic cells. 2020. 155p. Doctoral thesis. Ribeirão Preto Medical School Universityof São Paulo, Ribeirão Preto, 2020.

During infectious processes, there is intense recruitment of phagocytes, such as neutrophils and monocytes to the affected tissue, in an attempt to contain bacterial proliferation. These cells, after exercising their effector functions, enter cell death process, resulting in an intense accumulation of infected-apoptotic cells in the tissue. The phagocytosis of these apoptotic cells, called efferocytosis, is a dynamic process of fundamental importance for tissue homeostasis, thereby preventing tissue necrosis. Among these phagocytes, macrophages are important both in the defense against microorganisms and the removal of these apoptotic cells.

There are at least two populations of macrophages that differ in terms of activation status and immune function. M1 macrophages are pro-inflammatory and specialized in controlling infections, while M2 macrophages are anti-inflammatory and are related to tissue repair. To date, little is known about the effect of phagocytosis of infected and sterile apoptotic cells on the differentiation of these subpopulations of M1 / M2 macrophages. Here, we demonstrated that the efferocytosis of Streptococcus pneumoniae-infected apoptotic cells (AC-Sp) induces a mixed polarization profile dependent on the signaling pathways triggered by the TLR2 and TLR4 receptors, activation of NF- $\kappa \mathrm{B}$, STAT1 and STAT3 transcription factors and caspase 11 . On the other hand, the efferocytosis of of Klebsiella pneumoniae-infected apoptotic cells (AC$K p$ ) induces the activation of M1 profile dependent on NF-kB and STAT1. In vivo, the challenge with AC-Sp induces a less inflammatory microenvironment, while the challenge with AC-Kp results in the production of both inflammatory and antiinflammatory mediators in the pulmonary microenvironment.This study contributes to the understanding of how efferocytosis of infected-apoptotic cells by different bacterias can directly regular the macrophage activation and differentiation in M1/M2 profile and effector functions both in resolving the infection and in restoring tissue homeostasis.
\end{abstract}


Keywords: M1/M2 macrophages, efferocytosis, Streptococcus pneumoniae, Klebsiella pneumoniae, apoptotic cells. 


\section{INTRODUÇÃO}

\subsection{Reconhecimento de células apoptóticas e o impacto nas células do sistema} imune

O sistema imune é composto por diferentes tipos celulares, cada qual com funções especializadas. Essas células trabalham juntas no reconhecimento de patógenos, de estímulos ambientais, de antígenos próprios, entre outros, para a manutenção da homeostasia do nosso corpo. São categorizadas em sistema imune inato e sistema imune adaptativo.

As células do sistema imune inato, como macrófagos e células dendríticas (CD), são imprescindíveis tanto por atuarem como primeira linha de defesa do nosso organismo contra diferentes patógenos como também na remoção de células apoptóticas (1).

O processo apoptótico é caracterizado pela condensação e fragmentação da cromatina no interior do núcleo, retração celular, formação de vesículas apoptóticas, perda da adesão a matrizes celulares e liberação de moléculas que sinalizam e facilitam o reconhecimento das células apoptóticas por fagócitos (2). Estima-se que, diariamente, cerca de 300 bilhões de células entrem em apoptose no nosso corpo como parte do processo homeostático natural (3). Entre estas, estão células senescentes que necessitam substituição por novas células, linfócitos B e T durante o processo de maturação $(4,5)$, neutrófilos e hemácias que possuem curto tempo de vida, $24 \mathrm{~h}$ e 4 meses, respectivamente, por exemplo $(3,6)$.

Embora haja essa constante geração de células apoptóticas nos diferentes tecidos, a detecção destas, in vivo, é extremamente rara, sugerindo que essas células são eliminadas de forma extremamente rápida e eficiente $(7,8)$. Um milhão de células apoptóticas injetadas no peritônio de camundongos são capturadas em cerca de 15-30 minutos garantindo, assim, a homeostasia tecidual (3). Estima-se que, a cada segundo, por volta de $10^{6}$ células são depuradas no nosso organismo (8). A falha na remoção dos corpos apoptóticos resulta na geração de necrose secundária, liberação de DAMPs (Damage Associated Molecular Pattern) e inflamação (3). 
Uma das principais moléculas envolvidas no reconhecimento de células apoptóticas por fagócitos é a fosfatidilserina (PS). Em células viáveis, a PS é expressa na camada interna da membrana celular. Entretanto, durante o processo apoptótico, as moléculas de PS passam a ser expressas na superfície celular e dispostas em cluster (9). O reconhecimento de PS pode ocorrer pela interação com receptores como BAI 1 (brain specific angiogenesis inhibitor 1) (9, 10), stabilin 2 (11, 12), RAGE (Receptor for advanced glycationend products) (13) e TIM1/3/4 ( $T$ cell immunoglobulin mucin domain) $(14,15)$. Greenberg, et al. demonstraram que o receptor scavenge CD36 também está envolvido nos processos de eferocitose via moléculas de PS oxidadas (PSOX), assim como outros receptores scavenger como SR-A, SR-B $(16,17)$.

A fagocitose de células apoptóticas, denominada de eferocitose, também pode ser facilitada pela participação de moléculas bridge que se ligam a PS exposta na membrana de células apoptóticas e intermediam a interação com os receptores em fagócitos, como a glicoproteína MFG-E8 que interliga a PS à integrinas $\alpha v \beta 3$ expressas na superfície de macrófagos, e as opsoninas Gas 6 e a proteína S que ligam-se à PS e medeiam a interação com o receptor da tirosina quinase Mer (MerTK) $(7,18)$.

Embora a externalização da PS seja o evento mais descrito durante o processo de apoptose celular, estudos demostraram que outros fosfolipídeos, como fosfatidiletanolamina, fosfatidilcolina, proteínas como a calreticulina e a trombospondina-1 também são expostas na superfície da célula durante o processo apoptótico e colaboram para o reconhecimento das células apoptóticas pelos fagócitos (19-21). Vale ressaltar, que nem toda a exposição de PS na membrana celular está relacionada com a indução de apoptose, uma vez que trabalhos demonstram a expressão transiente dessa molécula durante a degranulação de mastócitos (22) e ativação de linfócitos (23). Além disso, moléculas como a galectina 1 também induzem a expressão de PS não relacionada com o processo apoptótico (24).

Além das moléculas ancoradas na membrana plasmática, o processo apoptótico induz a liberação moléculas denominadas de sinais find-me que geram um gradiente quimioatrativo favorecendo o encontro entre células apoptóticas e fagócitos como ATP/UTP/AMP (adenosine/uridinetriphosphate/adenosinemonophosphate), $\mathrm{CX}_{3} \mathrm{CL} 1$ 
(chemokine (C-X3-C motif) ligand 1), LPC (lysophosphatidylcholine) e S1P (sphingosine-1-phosphate) $(7,21)$.

Estudos têm demonstrado que os sinais find-me podem também desempenhar outras funções relacionadas à ativação celular. Por exemplo, $\mathrm{CX}_{3} \mathrm{CL} 1$ induz a expressão da glicoproteína MFG-E8 em macrófagos peritoneais (25) enquanto LPC está relacionado com aumento da expressão de MCP-1 (Monocyte chemoattractant protein 1) e RANTES (Regulated on Activation, Normal T Cell Expressed and Secreted) em células do endotélio vascular humano potencializando o recrutamento de monócitos pra o encontro com células apoptóticas e aumentando o índice de eferocitose (26). A molécula de AMP, uma vez metabolizada em adenosina, promove a inibição de mediadores inflamatórios por macrófagos (27). S1P induz aumento de mediadores antiinflamatórios como interleucina (IL)-10 e supressão de mediadores inflamatórios como IL-12 e TNF- $\alpha$ durante a eferocitose por macrófagos tumorais (28).

Os fagócitos profissionais, macrófagos e CDs imaturas, bem como os fagócitos não profissionais, células epiteliais, endoteliais, fibroblastos e outros, são responsáveis pelo processo de eferocitose (29) que pode ocorrer em diferentes cenários, como durante a manutenção da homeostasia natural dos nossos organismos ou durante o desenvolvimento e controle de doenças envolvendo ou não a presença de microrganismos. Doenças degenerativas do sistema nervoso como Alzheimer e Parkinson (30), doença pulmonar obstrutiva crônica (DPOC) causada pela inalação crônica de partículas e gases tóxicos (31), entre outras, são caracterizadas por um acúmulo intenso de células apoptóticas. Essas células são oriundas dos tecidos acometidos pela doença e, portanto, não apresentam nenhum componente não próprio ao organismo.

Por outro lado, durante um quadro infeccioso, com a presença de bactérias ou demais microrganismos, tanto células dos tecidos podem ser infectadas como também neutrófilos e monócitos que migram para o local da infecção na tentativa de conter a proliferação bacteriana apresentam patógenos em seu interior, resultando em um intenso acúmulo de células apoptóticas infectadas neste tecido.

No entanto, a eferocitose destas diferentes fontes celulares por fagócitos leva a geração de um microambiente com a liberação de distintos perfis de citocinas e 
mediadores lipídicos que interferem na ativação de CDs e macrófagos, assim como na diferenciação de sub populações de macrófagos e linfócitos T $(32,33)$. Sabe-se que a fagocitose de células apoptóticas estéreis resulta na produção de mediadores, tais como TGF- $\beta$ (Transforming Growth Factor Beta), IL-10, prostaglandina $\mathrm{E}_{2}\left(\mathrm{PGE}_{2}\right)$ e fator ativador plaquetário (PAF) assim como a inibição de componentes da resposta inflamatória, como IL-8, GM-CSF (Granulocyte-Macrophage Colony-Stimulating Factor), TNF- $\alpha$ (Tumor Necrosis Factor Alfa), bem como leucotrieno C4 e tromboxano B2 $(27,34,35)$.

Por outro lado, a eferocitose de células apoptóticas infectadas por bactérias promove, além da ativação via receptores e moléculas citadas acima, a ativação celular decorrente da interação de PAMPs (Pathogen Associated Molecular Patterns), contidos no interior de células apoptóticas infectadas, com receptores de reconhecimento de padrões (PRR) contidos no interior de vesículas endocíticas. A fagocitose de neutrófilos apoptóticos infetados com Citrobacter rodentium promove a síntese de IL-23, TGF- $\beta$ e IL-6 por CDs (36). A interação dos PAMPs presentes no interior da célula apoptótica infectada com PRRs do tipo TLRs (Toll Like Receptors) foi determinante para a geração desses fatores solúveis, visto que o padrão de citocinas liberadas nesse contexto se mostrou distinto quando comparado com a fagocitose de células apoptóticas estéreis pelos mesmos fagócitos (36).

\subsection{Reconhecimento de patógenos e ativação de células da imunidade inata}

Células do sistema imune inato utilizam PRRs para detectar PAMPs, DAMPs e células apoptóticas. Dentre as funções dos PRR estão: estimulação da fagocitose, produção de citocinas e mediadores inflamatórios, promoção de quimiotaxia e ativação celular (37).

Dentre os PRRs, os receptores do tipo toll são moléculas expressas por diferentes tipos celulares capazes de reconhecer uma ampla gama de PAMPs derivados dos mais diferentes patógenos. De maneira geral, os TLR1, 2, 4, 5 e 6 são expressos na membrana celular, enquanto TLR3, 7, 8 e 9 são expressos quase que exclusivamente em vesículas endocíticas no citoplasma (37). Entretanto, TLR4, inicialmente descrito como 
receptor de membrana celular, pode, também, ser encontrado na membrana de fagossomos ou de endossomos precoces $(36,37)$.

De maneira geral, a interação dos TLR com seu ligante específico desencadeia a ativação de proteínas adaptadoras como MyD88 (myeloid differentiation factor 88), TIRAP (TIR-associated protein), MAL (MyD88 adaptor-like protein), TRIF (TIR domain-containing adaptor protein including interferon) e TRAM (TRIF-related adaptor molecule) (37). O recrutamento destas proteínas adaptadoras resulta na ativação

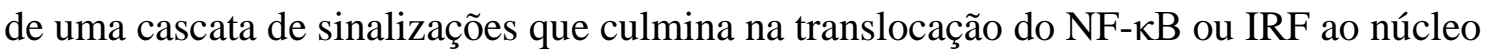
para ativação dos genes de citocinas pró-inflamatórias, TNF- $\alpha$ e IL-1 $\beta$ ou citocinas da família de interferon tipo 1 , respectivamente $(37,38)$.

Os receptores TLR1/2 e TLR2/6 estão presentes na superfície dos fagócitos e reconhecem lipopeptídeos presentes em bactérias Gram-positivas (38). Sabe-se que o Streptococcus pneumoniae $(S p)$ pode desencadear ativação das células via TLR2 através do reconhecimento do ácido lipoteicóico (LTA). Esta interação resulta na produção de mediadores, como TNF- $\alpha$, IL-1 $\beta$, IL-8, IFN $\alpha / \beta$, MCP-1 e IL-6, assim como no influxo de neutrófilos para o local da infecção, migração de monócitos e ativação de CDs que levam a diferenciação de células Th1 e Th17 (39-41). Durante a infecção por $S$. pneumoniae, a ativação das células do sistema imune também pode ocorrer via TLR4 pela interação com toxinas, como a pneumolisina (41). Animais deficientes de TLR4, quando infectados com S. pneumoniae, apresentam uma maior susceptibilidade à infecção e aumento da carga bacteriana, confirmando a importância deste receptor no reconhecimento e na ativação celular, o que resulta no controle da proliferação bacteriana (42). Assim, TLR2 e TLR4 parecem agir de forma sinérgica no controle do $S$. pneumoniae, uma vez que camundongos deficientes para ambos os receptores apresentam maior susceptibilidade, maior carga bacteriana, menor influxo de leucócitos e redução da produção de IL-1 $\beta(43,44)$.

Bactérias Gram-negativas, como a Klebsiella pneumoniae (Kp), expressam na membrana celular um polissacarídeo denominado LPS (Lipopolysaccharide), capaz de interagir e ativar moléculas como TLR4 e seus co-receptores, MD2 e CD14 (37). Animais deficientes de TLR4, quando desafiados com $K$. pneumoniae apresentam 
redução na sobrevivência e aumento na proliferação bacteriana nos pulmões quando comparados aos animais selvagens (WT) (42).

Além dos TLRs, os NOD (Nucleotide-binding and oligomerization domain) like receptors são proteínas presentes no citoplasma celular que atuam no reconhecimento de PAMPs. Essa família de receptores é dividida em cinco diferentes subfamílias de acordo com a estrutura que apresentam: NLRA, NLRB, NLRC, NLRP e NLRX (45). A ativação de NLRs desencadeia diferentes funções, como formação do inflamassoma, transdução de diversas vias de sinalização, ativação da transcrição gênica e autofagia $(46,47)$. Os membros da família NLR mais estudados são os subgrupos NLRC e NLRP, os quais pertencem NOD-1/2 (NLRC1/NLRC2) e NLRP3, respectivamente $(45,46)$.

O receptor NLRP3 é um dos NLR relacionados com a ativação do inflamassoma (46). O inflamassoma é uma plataforma multiproteica presente no citoplasma celular na forma de complexos inativos pré-montados. Em macrófagos, a ativação de NLRP3 requer duas etapas distintas: priming e ativação (48). O priming, também denominado de primeiro sinal, ocorre via estímulos inflamatórios como os derivados de TLRs e induz a ativação de NF-kB e transcrição de genes relacionados aos componentes do inflamassoma. A interação dos receptores aos seus respectivos ligantes (PAMPs ou DAMPs), denominado de segundo sinal, induz a ativação do inflamassoma promovendo mudanças conformacionais e a montagem da plataforma multiproteica, levando a ativação da molécula de caspase 1 , que é imprescindível para clivagem de pró-IL-1 $\beta$ e pró-IL-18 em suas formas maduras e biologicamente ativas, IL-1 $\beta$ e IL-18 $(47,48)$.

McNeela e colaboradores demonstraram que pneumolisina secretada pelo $S$. pneumoniae induz a formação de poros na membrana celular do hospedeiro, gerando efluxo de $\mathrm{K}+$, e desestabilização lisossomal, como liberação de catepsina B, ambos os eventos são relacionados com a ativação de NLRP3 (49). Animais deficientes para NLRP3 apresentam maior susceptibilidade à infecção por S. pneumoniae produtor de pneumolisina (50). Animais deficientes de ASC (apoptosis associated speck-like containing a CARD domain), molécula adaptadora tanto do inflamassoma de NLRP3 quanto de AIM2, são mais suscetíveis à infecção por essa bactéria também (51). Além 
disso, K. pneumoniae via polissacarídeo capsular também induz ativação do inflamassoma de NLRP3 e produção de IL-1 $\beta$ (52).

Além da ativação canônica do inflamassoma descrita acima, dados da literatura demonstram que o inflamassoma também pode ser ativado de forma não canônica via ativação de caspase 11, em camundongos (caspase 4 e 5, em humanos). A molécula de caspase 11 é composta por 3 fragmentos: uma porção CARD, uma porção p20 e a porção C-terminal, p10 (53). Caspase 11 é ativada em resposta ao LPS presente no citosol celular derivado de bactérias Gram-negativas, independentemente da interação dessa molécula com o receptor TLR4, culminado na formação de poros via gasdermina D $(53,54)$. Camundongos deficientes de caspase 11, quando infectados com $K$. pneumoniae, apresentam uma deficiência no recrutamento de neutrófilos e combate bacteriano nos estágios iniciais da infecção (55). Além disso, Zanoni e colaboradores demonstraram que DAMPs como oxPAPC (Oxidized phospholipids derived from 1palmitoyl-2-arachidonyl-sn-glycero-3-phosphorylcholine) produzidos durante o dano tecidual também podem ativar a via não canônica do inflamassoma e produção de IL-1 $\beta$ sem induzir morte celular por piroptose em $\operatorname{CD}(56,57)$.

Apesar de ser bem descrito quais são os PAMPs/DAMPs que interagem com os respectivos PRRs e as cascatas de sinalização ativadas, não está claro como a fagocitose de células apoptóticas infetadas com S. pneumoniae ou K. pneumoniae poderia induzir a ativação de macrófagos, uma vez que, nesse contexto também teremos a ativação de vias sinalização gerada pelo reconhecimento de PS aos seus respectivos receptores.

\subsection{Ativação de macrófagos M1/M2 no contexto de eferocitose}

Os macrófagos residentes são células mielóides que podem ser derivadas tanto de precursores da medula óssea quanto do fígado fetal e saco vitelino (58). Desde as primeiras etapas de vida fetal até a vida adulta, os macrófagos residem em diferentes tecidos periféricos do nosso organismo (58). Sabe-se que os órgãos do nosso organismo são povoados por macrófagos derivados de diferentes precursores, como por exemplo, macrófagos derivados do saco vitelino dão origem principalmente a micróglia cerebral, macrófagos precursores do fígado fetal estão relacionados com a população de células Kupffer do fígado e macrófagos alveolares e, por outro lado, macrófagos derivados da 
medula óssea são importantes para a geração de macrófagos residentes do intestino, derme e coração $(58,59)$. Os mais diferentes macrófagos podem auxiliar tanto na manutenção da integridade e remodelamento de tecidos danificados bem como no cambate à patógenos e na destruição desses tecidos devido à produção de mediadores inflamatórios e enzimas proteolíticas, por exemplo, durante processos inflamatórios crônicos (60).

Atualmente, são descritas ao menos duas populações distintas de macrófagos que diferem quanto ao estado de polarização e função imunológica dependente do microambiente onde essas células estão inseridas $(60,61)$ e da interação patógenocélula do hospedeiro (62). A polarização de macrófagos é um processo que desencadeia uma profunda reprogramação transcricional, levando essas células a adquirirem um fenótipo específico em resposta aos diferentes estímulos presentes no microambiente tecidual.

A ativação de macrófagos pela via clássica desencadeia o desenvolvimento de macrófagos tipo I (M1), que se polarizam em resposta a estímulos patogênicos, sinais endógenos de perigo e presença de citocinas como IFN- $\gamma$ e TNF- $\alpha(60,63)$. A ativação ao perfil M1 é decorrente da ativação de receptores como TLR, RLR (RIG-I-like receptors) e NOD-like, que culminam na ativação de fatores de transcrição como NFкB, AP-1, C/EBPb, STAT1, PU.1 e IRFs. Essas células possuem alta capacidade de secretar citocinas pró-inflamatórias, como TNF- $\alpha$, IL-12, IL-23, IL-1 $\beta$, IL-1 $\alpha$ e IL-6 (64-68) e podem ser caracterizadas por diversos marcadores, como iNOS, TLR2/4, CD16, ferritina, SOCS3, CD80 e MARCO (63, 66, 67). Além disso, os macrófagos M1 possuem um papel chave na remoção e destruição de bactérias devido sua capacidade de produzir fatores microbicidas como óxido nítrico (NO) e reativos de oxigênio $(62,65$, $66,69)$.

A ativação de macrófagos pela via alternativa, por outro lado, promove a diferenciação de macrófagos tipo 2 (M2). Os macrófagos M2 são células com perfil anti-inflamatório e produção de citocinas como IL-10 e TGF- $\beta$ (64, 65), que exibem funções imunossupressoras como, por exemplo, a inibição da proliferação de linfócitos T. As moléculas como Arginase 1, Ym 1/2, Fizz1/2, CD206, receptor de Folato, 
SOCS1, Dectina-1, são preconizadas como marcadores para essas subpopulações (63, $64,66,67,70)$.

Os macrófagos M2 apresentam alta capacidade de proliferação, eferocitose e remodelação tecidual promovendo uma melhor cicatrização de lesões devido ao metabolismo da arginase, que desencadeia a produção de poliaminas e prolinas que atuam nesse contexto (71).

Martinez e colaboradores demonstraram que a fagocitose de células apoptóticas não infectadas desencadeia uma baixa expressão de marcadores associados a um perfil M1 e o aumento na expressão de moléculas associadas um perfil de ativação M2, como Arginase-1, IL-4, IL-10 (72). Diferentes estudos mostraram que o reconhecimento de sinais find-me durante a eferocitose de células apoptóticas estéreis por macrófagos, desencadeia na supressão de citocinas pró-inflamatórias (TNF- $\alpha$, IL-12, CXCL1 e CXCL2) e a regulação positiva de fatores pré-resolutivos (Nr4a1 e Thbs1), IL-10, $\mathrm{PGE}_{2}$, fator de crescimento endotelial vascular e inibição de $\mathrm{NF}-\kappa \mathrm{B}(7,28,73-76)$. Além disso, a eferocitose de células apoptóticas estéreis promove a ativação do perfil M2 em macrófagos via PPAR- $\gamma / \delta$ e receptor X do fígado (LXR) (77).

Somado a isso, estudos demonstram que a via não canônica de autofagia também está relacionada com a remoção de células apoptóticas e ativação de macrófagos (7880). Cunha e colaboradores demonstraram que a eferocitose induz a ativação de proteínas autofágicas promovendo a rápida fusão entre fagosomo ao lisossomo e, consequentemente, eficiente degradação da célula apoptótica, liberação de mediadores anti-inflamátorios e polarização de macrófagos M2 (80). Entretanto, pouco se sabe sobre quais vias de sinalização são ativadas durante a fagocitose de células apoptóticas infectadas e como essa ativação direciona a diferenciação de subpopulações de macrófagos M1/M2.

\subsection{Vias de sinalização intracelular envolvidas na ativação de macrófagos M1/M2}

Estudos demonstram que a ativação de macrófagos M1/M2 é dependente da via de sinalização IRF/STAT/SOCS. Em condições de repouso, os macrófagos apresentam baixa expressão dessas proteínas, entretanto, quando essas células são ativadas, elas são 
rapidamente expressas (67). A interação de ligantes de TLR4, como LPS, resulta na ativação da molécula adaptadoras como MyD88 e, consequentemente, do fator de

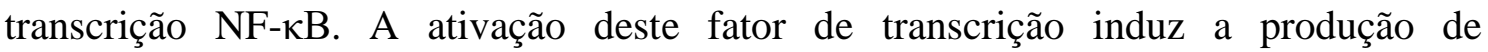
mediadores inflamatórios, como IFN- $\alpha / \beta \mathrm{s}$, que ativam fatores de transcrições como IRF3 e STAT1 e, portanto, levam a ativação de macrófagos e diferenciação para um perfil M1 $(81,82)$.

Por outro lado, a interação de IL-4 e IL-10 aos seus respectivos receptores induzem à ativação de macrófagos a um perfil M2, via STAT6 e STAT3, respectivamente. Wang e colaboradores demonstraram a importância de STAT3 na ativação de macrófagos $\mathrm{M} 2$ via $\mathrm{PGE}_{2}$ e miRNA-21 (83). IL-4 e IL-13 ativam as proteínas tirosinas quinases, JAK1 e JAK3, resultando na fosforilação e translocação de STAT6 ao núcleo e a transcrição de genes associado ao perfil de macrófagos M2, como CD206, Fizz1 e Ym1 (81, 82). A interação de IL-10 ao seu receptor resulta na fosforilação de resíduos de tirosina permitindo a ativação do fator de transcrição STAT3 e a redução da expressão de citocinas inflamatórias, como TNF- $\alpha$ (81).

Como citado, vários fatores são descritos como capazes de desencadear a ativação de macrófagos para um perfil M1/M2, como o microambiente contendo diferentes citocinas e mediadores lipídicos, a interação com patógenos e a expressão de diferentes moléculas reguladoras. Estudos prévios do nosso grupo demonstraram que a eferocitose de células apoptóticas infectadas com $S$. pneumoniae induz um perfil misto (M1/M2) de ativação em macrófagos, enquanto a eferocitose de células apoptóticas infectadas com E. coli induz a ativação de macrófagos M1. Entanto, nada se sabe sobre o efeito do reconhecimento das diferentes células apoptóticas infectadas na ativação das diversas vias de sinalização envolvidos na polarização de macrófagos M1/M2. 


\section{HIPÓTESE DE ESTUDO}

Este estudo foi baseado na hipótese de que a fagocitose de células apoptóticas infectadas com bactérias Gram-positivas ou Gram-negativas desencadearia diferentes vias de sinalização intracelular e de fatores de transcrição que influenciariam diretamente na ativação de macrófagos M1/M2.

Figura 1. A eferocitose de diferentes fontes de células infectadas promove a polarização diferenciada de macrófagos MO.

\section{AC-S. pneumoniae}

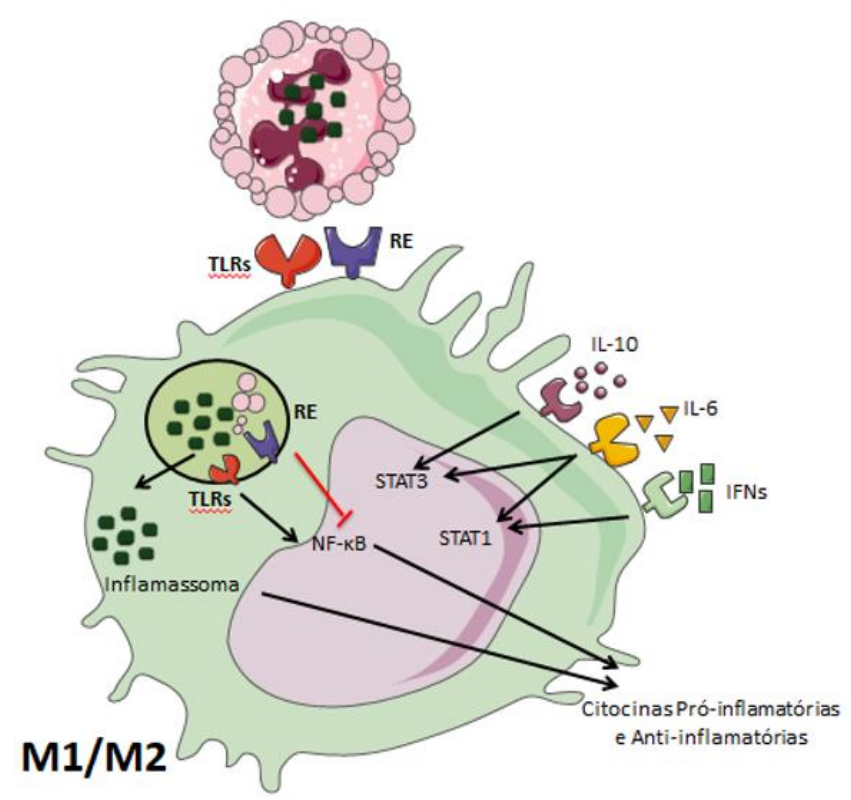

\section{AC-K. pneumoniae}

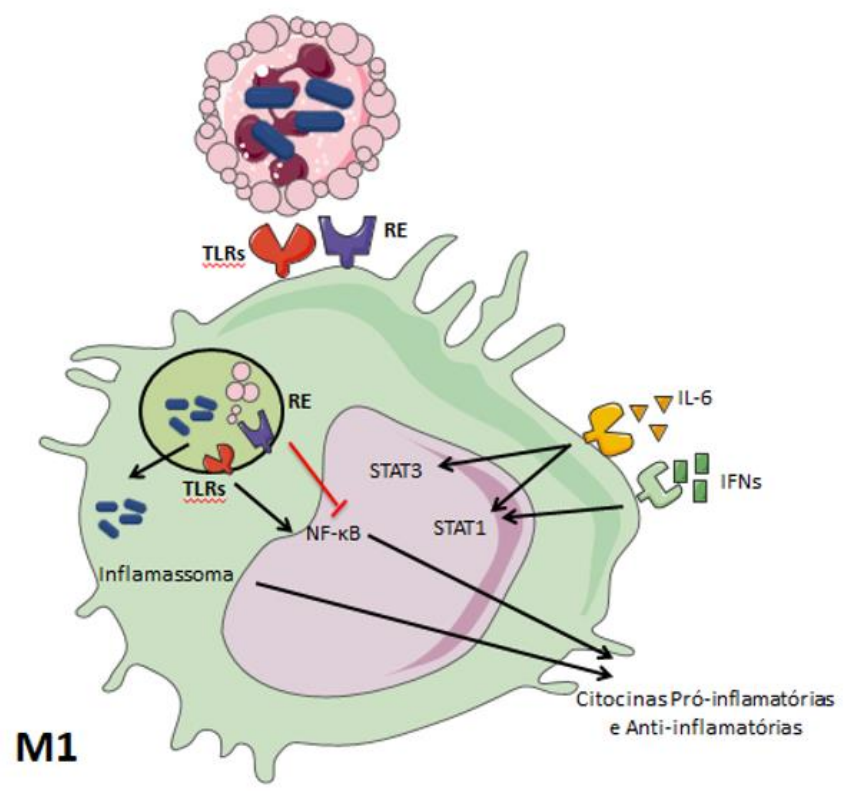

As células apoptóticas infectadas com $S$. pneumoniae (AC-Sp) ou infectadas com $K$. pneumoniae (AC-Kp) seriam reconhecidas tanto por receptores que respondem a sinais apoptóticos (Receptores eferocíticos - RE) quanto receptores específicos para os diferentes PAMPs expressos por esses patógenos. Os macrófagos M0 fagocitariam esses diferentes tipos celulares adquiririam perfis distintos de polarização: macrófagos M0 que fagocitariam AC-Sp apresentariam um padrão misto de polarização, enquanto a fagocitose de $\mathrm{AC}-\mathrm{K} p$ desencadearia um padrão de polarização de macrófagos M1. Após a degradação destas células apoptóticas infectadas no interior do fagolisossomo, diferentes PAMPs seriam disponibilizados no interior dessa vesícula ou transportados para o citoplasma. A interação destes PAMPs via diferentes receptores do tipo TLR, translocados para o interior de fagolisossomo durante o processo de fagocitose, ou receptores citoplasmáticos do complexo do inflamassoma, resultaria na ativação de diferentes cascatas bioquímicas, com ativação de fatores de transcrição e produção de citocinas. Essas distintas vias intracelulares desencadeadas pelo reconhecimento de PAMPs via PRRs resultariam na produção de citocinas nesses microambientes e, consequentemente, promoveriam a ativação de STATs, como STAT1 e STAT6/3, direcionando a polarização destes macrófagos em diferentes perfis M1/M2. 


\section{OBJETIVO}

O objetivo deste trabalho foi avaliar os mecanismos pelos quais a fagocitose de células apoptóticas infectadas com K. pneumoniae ou S. pneumoniae promove distintos fenótipos de ativação de macrófagos.

\subsection{Objetivos específicos}

1) Determinar, in vitro, o perfil de ativação de macrófagos na presença de células apoptóticas infectadas com S. pneumoniae (AC-Sp) ou K. pneumoniae (AC-Kp);

2) Identificar os PRRs envolvidos na ativação de macrófagos M1/M2 pela eferocitose de células infectadas com AC-Sp ou AC-Kp;

3) Avaliar os fatores de transcrição envolvidos na ativação de macrófagos M1/M2 durante a eferocitose de células apoptóticas infectadas com AC-Sp ou AC-Kp;

4) Determinar, in vivo, o impacto da instilação de células apoptóticas infectadas com S. pneumoniae ou K. pneumoniae no ambiente pulmonar. 


\section{MATERIAL E MÉTODOS}

\subsection{Animais}

Animais C57BL/6, fêmeas, com 6 a 12 semanas de idade, foram obtidos do Centro Multidisciplinar para Investigação Biológica - CEMIB/UNICAMP ou do Biotério Geral - USP/Ribeirão Preto. Animais deficientes para os receptores TLR2 (B6.129-Tlr2 $\left.{ }^{\mathrm{tm} 1 \mathrm{Kir}} / \mathrm{J}\right)$ foram obtidos no Centro de Criação de Camundongos Especiais FMRP/USP. Animais deficientes para os receptores TLR4 (B6.129-Tlr4 $\left.{ }^{\mathrm{tm} 1 \mathrm{Kir}} / \mathrm{J}\right)$ foram obtidos do Biotério de Matrizes de Camundongos - ICB/USP. Animais deficientes em caspase 11 foram gentilmente cedidos pelo professor Dr. Dario Simões Zamboni FMRP/USP. Todos os procedimentos experimentais passaram por aprovação da Comissão de Ética no Uso de Animais - CEUA (número: 59-2016), Faculdade de Ciências Farmacêuticas da Universidade Estadual Paulista "Júlio de Mesquita Filho" Campus de Araraquara.

\subsection{Cultivo de S. pneumoniae}

A cepa de $S$. pneumoniae utilizada nesse trabalho foi a cepa ATCC 49619 gentilmente cedida pela $\operatorname{Prof}^{\mathrm{a}} \operatorname{Dr}^{\mathrm{a}}$ Ana Gales. O estoque bacteriano foi mantido em alíquotas congeladas à $-80^{\circ} \mathrm{C}$. No dia anterior ao experimento, as alíquotas de $S p$ foram descongeladas e cultivadas em $10 \mathrm{~mL}$ de TSB (tryptic soy broth) à $37^{\circ} \mathrm{C}$ e sob agitação por 6h. Após esse período, a solução foi centrifugada a 15.000 RPM por 10 minutos a $4^{\circ} \mathrm{C}$. Em seguida, o sobrenadante foi desprezado, as bactérias foram ressuspensas em 5 $\mathrm{mL}$ de PBS 1x e centrifugadas novamente. A concentração do inóculo foi confirmada em placas de ágar sangue a partir de diluições seriadas na base 10. As placas foram incubadas por $18 \mathrm{~h}$ à $37^{\circ} \mathrm{C}$ e $5 \% \mathrm{CO}_{2}$ e a solução de inóculo mantida a temperatura de $4^{\circ} \mathrm{C}$ até o momento do experimento. Após esse período, as unidades formadoras de colônias (UFC) foram contadas para a determinação da carga real do inóculo e infecção das células HL-60. 


\subsection{Cultivo de $K$. pneumoniae}

A cepa de $K$. pneumoniae utilizada nesse trabalho foi isolada de hemocultura de paciente internado no Hospital Universitário - Unifesp e cedida pela $\operatorname{Prof}^{\mathrm{a}} \operatorname{Dr}^{\mathrm{a}}$ Ana Gales. $\mathrm{O}$ estoque bacteriano foi mantido em alíquotas congeladas à $-80^{\circ} \mathrm{C}$. Três dias antes do experimento as alíquotas foram plaqueadas em ágar MacConkey e incubadas por $18 \mathrm{~h}$ à $37^{\circ} \mathrm{C}$ e $5 \% \mathrm{CO}_{2}$. Após esse período, uma colônia bacteriana foi adicionada a $10 \mathrm{~mL}$ de TSB e incubada a $37^{\circ} \mathrm{C}$ por $18 \mathrm{~h}$. Em seguida, $100 \mu \mathrm{L}$ dessa solução foi adicionado a $10 \mathrm{~mL}$ de TSB novo e incubada a $37^{\circ} \mathrm{C}$ sob agitação por $5 \mathrm{~h}$. Após esse período, solução foi centrifugada a $15.000 \mathrm{RPM}$ por 10 minutos a $4^{\circ} \mathrm{C}$, o sobrenadante foi desprezado, as bactérias foram ressuspensas em $5 \mathrm{~mL}$ de PBS 1x e centrifugadas novamente. A concentração do inóculo foi confirmada em placas de ágar MacConkey a partir de diluições seriadas na base 10 . As placas foram incubadas por $18 \mathrm{~h}$ à $37^{\circ} \mathrm{C}$ e $5 \%$ $\mathrm{CO}_{2}$ e a solução de inóculo mantida a temperatura de $4^{\circ} \mathrm{C}$ até o momento do experimento. Após esse período, as UFC foram contadas para a determinação da carga real do inóculo e infecção das células HL-60.

\subsection{Obtenção de Células Apoptóticas Infectadas oriundas da linhagem celular neutrofílica HL-60}

A linhagem celular neutrofílica humana HL-60 obtida no banco de células do Rio de Janeiro/BCRJ-UFRJ foi mantida em garrafas estéreis de cultura de tecidos (75 $\mathrm{cm}^{2}$ ) com meio de cultura DMEM (Dulbecco's modified Eagle médium - Lonza), suplementado com $10 \%$ de soro fetal bovino (SFB) e gentamicina, a $37^{\circ} \mathrm{C}_{\text {em } \mathrm{CO}_{2} \text { a }}$ $5 \%$. As células HL-60 foram tratadas durante $72 \mathrm{~h}$ com meio DMEM com 1,2\% de DMSO para estimular a maturação final a neutrófilos e, em seguida, cocultivadas com $S$. pneumoniae ou $K$. pneumoniae, por $2 \mathrm{~h}$ horas, com diferentes multiplicidades de infecção (MOI). Uma vez infectados, esses neutrófilos-like foram submetidos ao protocolo de indução apoptose por radiação U.V.C., seguida de incubação por 4h, conforme descrito previamente por Torchinsky et al. (33). A porcentagem de apoptose dessas células foi confirmada por citometria de fluxo (BD FACSVerse ${ }^{\mathrm{TM}}$ ), utilizando a marcação de Anexina V/7-AAD (BD Biosciences) 


\subsection{Diferenciação de macrófagos M0 a partir de precursores de Medula Óssea}

Os macrófagos foram diferenciados a partir da suspensão celular obtida pela lavagem da medula óssea do fêmur e tíbia e cultivadas na presença de $60 \mathrm{ng} / \mathrm{mL}$ M-CSF e $30 \mathrm{ng} / \mathrm{mL}$ de GM-CSF (PeproThec) (84, 85). No sétimo dia de cultura, as células aderentes foram coletadas e avaliadas por qPCR e, o sobrenadante de cultura celular foi utilizado para a avaliação do perfil de citocinas produzido por essas células.

\subsection{Determinação da eferocitose de células apoptóticas}

Macrófagos M0 foram cocultivados na proporção de 3:1 (3 AC:1 M0) na presença de diferentes fontes de células apoptóticas, AC, AC-Kp ou AC-Sp marcadas com $5 \mu \mathrm{M}$ de CFSE (Cell Trace ${ }^{\mathrm{TM}}$ CFSE Cell Proliferation Kit - Thermo Fisher Scientific), por $2 \mathrm{~h}$ ou $4 \mathrm{~h}$. Após esses períodos, as células foram coletadas, tratadas com azul de tripan $0,01 \%$ por 30 minutos. Em seguida, as células foram lavadas e analisadas por citometria de fluxo (BD FACSVerse ${ }^{\mathrm{TM}}$ ) para a determinação do índice de eferocitose utilizando os parâmetros de SSC vs CFSE ${ }^{+}$.

\subsection{Polarização de macrófagos M0 na presença de diferentes fontes de células apoptóticas}

Macrófagos M0 foram incubados por 24h na presença das diferentes fontes de células apoptóticas, AC, AC-Kp ou AC-Sp. Após esse período, as células foram coletadas e analisadas por qPCR e, no sobrenadante de cultura foram avaliadas as citocinas secretadas. Grupo M0+AC: macrófagos M0 incubados na presença de AC. Grupo M0+AC-Kp: macrófagos M0 incubados na presença de AC-Kp. Grupo M0+AC$S p$ : macrófagos M0 incubados na presença de AC-Sp.

\subsection{Avaliação das vias de sinalizações envolvidas na polarização de macrófagos}

Macrófagos M0 derivados da medula óssea de animais deficientes para TLR2, TLR4 e Caspase 11 foram incubados por 24h na presença das diferentes fontes de células apoptóticas, AC, AC-Kp ou AC-Sp. Utilizando uma estratégia farmacológica, os macrófagos M0 oriundos de animais WT foram pré-tratados por 30 minutos com

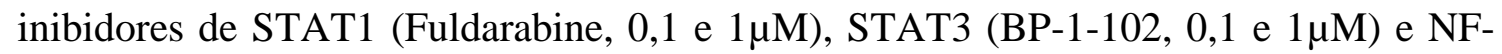


kB (Caffeic acid phenethylester, $5 \mu \mathrm{M}$ ). Após esse período, as células foram coletadas e analisadas por qPCR e no sobrenadante de cultura foram avaliadas as citocinas liberadas.

\subsection{Extração de RNA e síntese de cDNA}

Os diferentes macrófagos M0 foram incubados, por 24h, na presença das diferentes fontes de células apoptóticas, AC, AC-Kp ou AC-Sp. Após esse período, as células foram lisadas e a extração de RNA foi realizada conforme as especificações do fabricante do kit (RNAspin Mini RNA Isolation Kit- GE Healthcare) ou através do uso de isopropanol seguido de etanol $75 \%$ e aquecimento a $55^{\circ} \mathrm{C}$ por 10 minutos. O RNA extraído foi utilizado para a síntese de cDNA conforme as especificações do fabricante (iScript ${ }^{\mathrm{TM}}$ cDNA Synthesis Kit - Bio-Rad).

\subsection{Análise relativa dos níveis de mRNA por PCR em tempo real (qPCR)}

As reações quantitativas de PCR foram realizadas utilizando-se o agente intercalante Sybr Green (Power SYBR Green PCR Master Mix) no equipamento Applied Biosystems 7500 Real Time PCR System. Todas as reações foram realizadas de acordo com as recomendações do fabricante, sempre em duplicatas experimentais. Os dados obtidos foram analisados baseando-se no método de $2^{-\Delta \mathrm{CT}}$ (86), utilizando a média geométrica do gene de referência Gapdh como controle endógeno.

Tabela 1. Lista de primers utilizados para a fenotipagem dos macrófagos após a eferocitose de AC, AC-Sp e AC-Kp

\begin{tabular}{l|l|l}
\hline \multicolumn{1}{c|}{ Gene } & \multicolumn{1}{|c}{ Oligonucleotídeo F (5'-3') } & \multicolumn{1}{c}{ Oligonucleotídeo R (5'-3') } \\
\hline Gapdh & AACTTTGGCATTGTGGAAGG & ACACATTGGGGGTAGGAACA \\
\hline Arg 1 & CTCCAAGCCAAAGTCCTTAGAG & AGGAGCTGCTATTAGGGACATC \\
\hline$C C R 7$ & TTCCAGCTGCCCTACAATGG & GAAGTTGGCCACCGTCTGAG \\
\hline$C d 206$ & CCACAGCATTGAGGAGTTTG & ACAGCTCATCATTTGGCTCA \\
\hline Fizz1 & ACTGCCTGTGCTTACTCGTTGACT & AAAGCTGGGTTCTCCACCTCTTCA \\
\hline$C d 86$ & CATGGGCTTGGCAATCCTTA & AAATGGGCACGGCAGATATG \\
\hline
\end{tabular}




\subsection{Ensaio Imunoenzimático (ELISA)}

Os sobrenadantes das culturas foram avaliados quanto à presença das citocinas TNF- $\alpha$ (limite de detecção 31,3 pg/mL), IL-1 $\beta$ (limite de detecção 15,6 pg/mL), IL-10 (limite de detecção 31,3 pg/mL), TGF- $\beta$ (limite de detecção 31,3 pg/mL), das empresas BD Pharmingen ${ }^{\mathrm{TM}}$ ou R\&D System. A quantificação foi realizada de acordo com os protocolos dos respectivos fabricantes. Os resultados foram expressos em $\mathrm{pg} / \mathrm{mL}$. O experimento in vivo é representado por $\mathrm{pg} / \mu \mathrm{g}$ de proteína do tecido.

\subsection{Quantificação de Nitrito}

$\mathrm{O}$ óxido nítrico foi quantificado indiretamente pela produção de $\mathrm{NO}_{2}{ }^{-}$a partir da reação de Griess (solução estoque de NEED a $0,1 \%$ e sulfanilamida a $1 \%$ em $\mathrm{H}_{3} \mathrm{PO}_{4}$ $5 \%$ ) no sobrenadante de cultura celular. Os resultados foram expressos em $\mu \mathrm{M}$ de nitrito (87).

\subsection{Polarização de macrófagos in vivo}

Animais C57BL/6, com 5-8 semanas de idade foram separados em 3 grupos experimentais, cada um dos grupos contendo cinco animais. No primeiro dia de experimento, os animais receberam pela via intranasal (em $30 \mu \mathrm{L}$ ): PBS, ou $10^{7} \mathrm{AC}-\mathrm{Sp}$, ou $10^{7}$ AC- Kp. Após $24 \mathrm{~h}$, os animais foram eutanaziados e os dois lóbulos menores do pulmão foram utilizados para a quantificação citocinas por ELISA (descrito no item 4.11). Os outros lóbulos pulmonares foram macerados (GentleMACS Dissociator, Miltenyi Biotec) e digeridos por 1,6 mg/mL de colagenase D (Roche) por 1 hora. Em seguida, as células foram lisadas para a quantificação de mRNA como descrito nos itens 4.9 e 4.10 . 
Figura 2. Protocolo experimental in vivo de instilação de células apoptóticas infectadas.

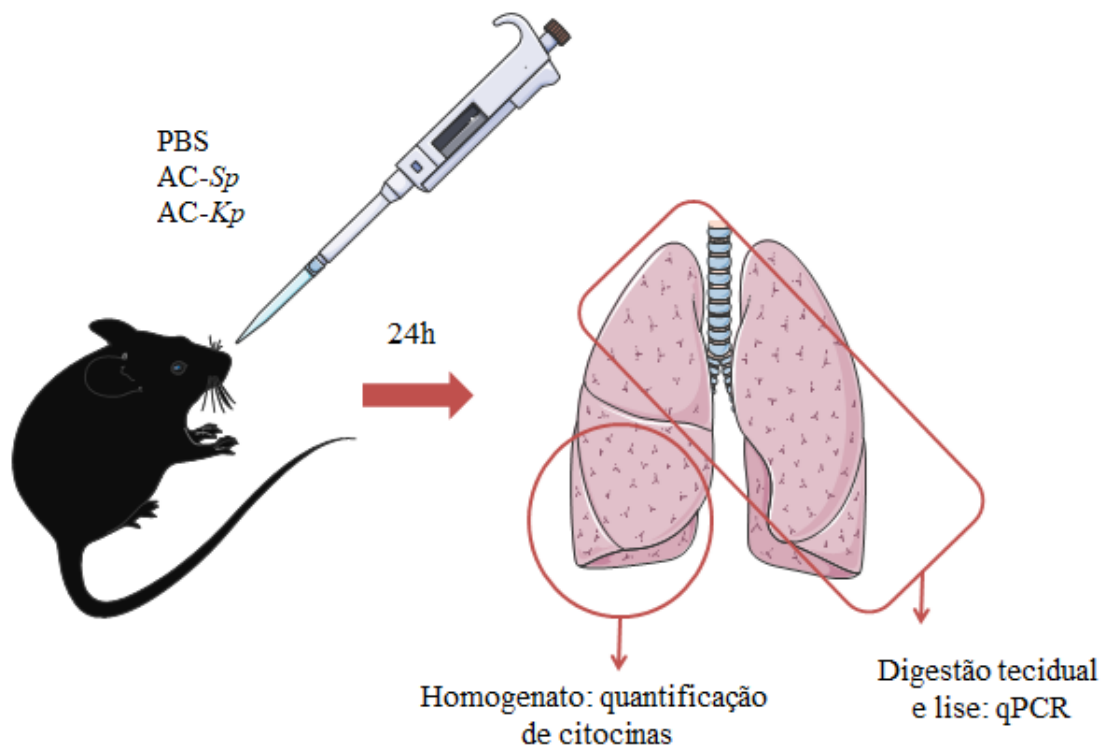

Os animais foram inoculados via intranasal com $30 \mu \mathrm{L}$ PBS, ou $10^{7} \mathrm{AC}-\mathrm{Sp}$, ou $10^{7} \mathrm{AC}-\mathrm{Kp}$. Após 24h, os animais foram eutanaziados e os dois lóbulos menores foram utilizados para a quantificação citocinas por ELISA e os três lóbulos restante foram utilizados para as análises de RT-qPCR. 


\subsection{Análise estatística}

Os resultados foram apresentados como média \pm SEM e foram analisados utilizando o programa estatístico Prism 8.0 (GraphPad Software, San Diego, CA). Para as comparações entre dois grupos experimentais foi utilizado o teste de Student's $t$ e para as comparações entre três ou mais grupos experimentais foi aplicada a análise de variância ANOVA seguido de teste de comparação múltipla Turkey. Foram consideradas diferenças estatisticamente significativas se $p \leq 0,05$. 


\section{RESULTADOS}

\subsection{Determinação da porcentagem de neutrófilos-like infectados}

Neutrófilos-like foram gerados a partir de células de linhagem celular humana HL-60 (Anexo 1). Para determinação da porcentagem de células infectadas, as diferentes cepas bacterianas (S. pneumoniae e K. pneumoniae) foram conjugadas com 5 $\mu \mathrm{M}$ de CFSE (Anexo 1) e incubadas com neutrófilos-like em MOI de 30, isto é, 30 UFC para cada neutrófilo-like, por 2 horas. Aproximadamente $90 \%$ dos neutrófilos foram infectados pela $K$. pneumoniae seguindo esse protocolo. Entretanto, na condição contendo S. pneumoniae cerca de $60 \%$ dos neutrófilos-like foram positivos para CFSE (Figura 3). Quanto à média da intensidade de fluorescência (MFI), que representa a quantidade de bactéria no interior de cada neutrófilo-like, a fagocitose de $K$. pneumoniae e S. pneumoniae por neutrófilos-like resultou em um MFI de 1776,78 e 1135,96 respectivamente (Figura 3).

$\mathrm{Na}$ tentativa de melhorar a porcentagem de infecção com a bactéria $S$. pneumoniae aumentamos a proporção desse patógeno na cultura, entretanto, o aumento do MOI induziu alta taxa de mortalidade nos neutrófilos-like cocultivados com essa bactéria (dados não mostrados). 
Figura 3. Determinação da porcentagem de fagocitose dos neutrófilos-like cultivados com S. pneumoniae ou K. pneumoniae.
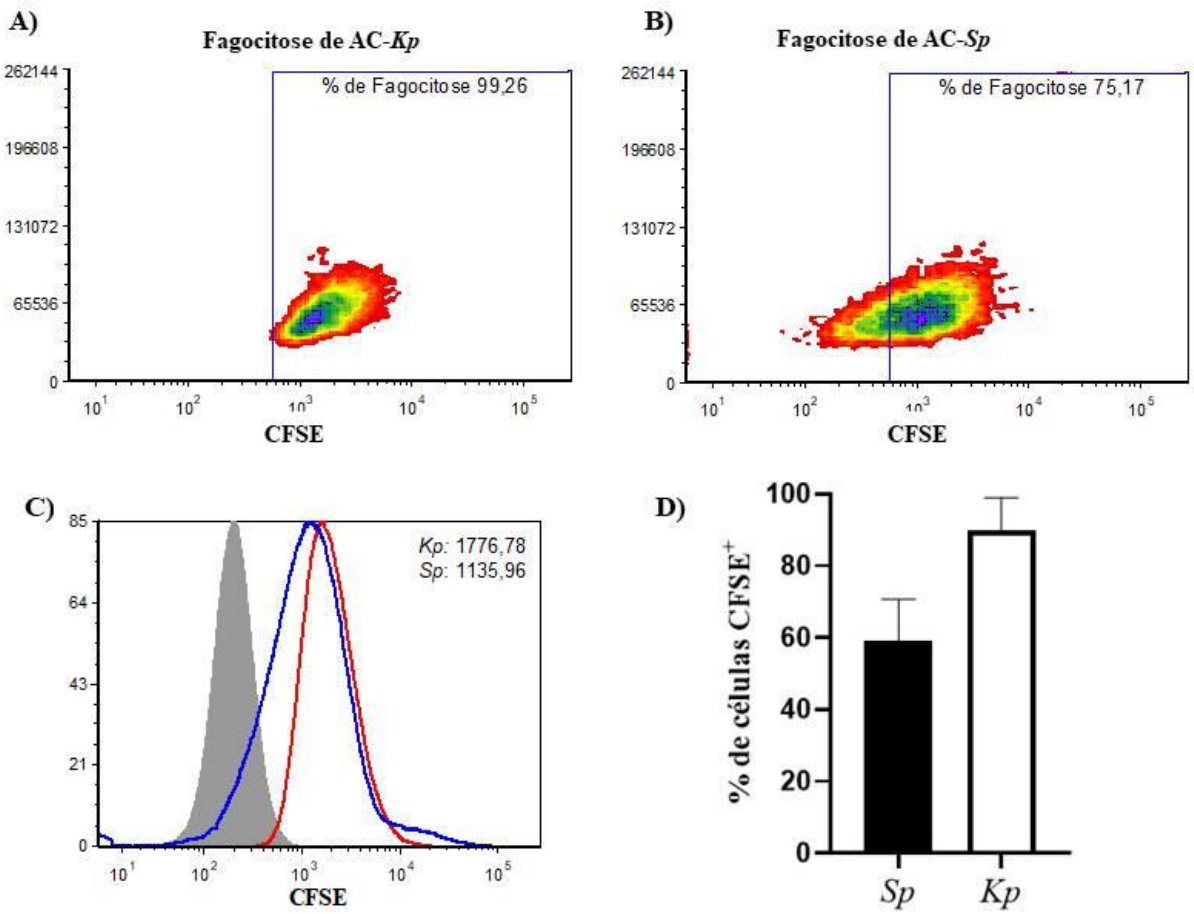

Os neutrófilos-like diferenciados na presença de 1,2\% de DMSO por $72 \mathrm{~h}$ foram cultivados com as duas cepas bacterianas, MOI de 30, marcadas com 5 $\mu \mathrm{M}$ de CFSE. A) Gráfico representativo da fagocitose de K. pneumoniae por neutrófilos-like. B) Gráfico representativo da fagocitose de S. pneumoniae por neutrófilos-like. C) Gráfico representativo do MFI de neutrófilos-like não infectados (histograma cinza), neutrófilos-like infectados com K. pneumoniae (linha vermelha) ou neutrófilos-like infectados com S. pneumoniae (linha azul). D) Somatória das porcentagens de fagocitose de $S$. pneumoniae e K. pneumoniae. Após 2 horas de fagocitose, as células foram coletadas e analisadas por citometria de fluxo. Os resultados são referentes a um experimento representativo de dois experimentos realizados individualmente. 


\subsection{Indução de apoptose celular em neutrófilos-like}

Uma vez padronizada a infecção dos neutrófilos-like, a próxima etapa foi determinar a apoptose das diferentes células infectadas e não infectada. Para isso, neutrófilos-like oriundos da HL-60 infectados com K. pneumoniae ou S. pneumoniae e não infectados passaram pelo processo de indução de apoptose.

Dois protocolos de indução de apoptose celular são bem estabelecidos em nosso laboratótio: i) Camptotecina, alcalóide citotóxico de origem vegetal capaz de inibir a enzima topoisomerase I, prejudicando, assim, o processo de replicação celular e desencadeando a apoptose celular (88) e ii) radiação ultravioleta C (UVC) que causa fragmentação da molécula de DNA, ativação de caspases e geração de espécies reativas que culminam no processo apoptótico (89). Optamos por utilizar o protocolo de radiação UVC devido a experiência prévia do nosso grupo e para evitar possíveis críticas relacionadas à presença de resíduos do alcalóide na cultura celular durante os experimentos subsequentes.

Dessa forma, os neutrófilos-like não infectados ou infectados com $K$. pneumoniae ou S. pneumoniae foram submetidos a $1 \mathrm{~mJ}$ ou $5 \mathrm{~mJ}$ de radiação. Após a exposição à radiação UVC, as células foram incubadas por $4 \mathrm{~h}$ ou $8 \mathrm{~h}$ para determinar intensidade de radiação e o melhor tempo de incubação para obtenção do maior número de células apoptóticas e um reduzido número de células necróticas nas diferentes condições experimentais. A incubação dos neutrófilos-like não infectados ou infectados com K. pneumoniae ou $S$. pneumoniae por $8 \mathrm{~h}$ bem como a utilização de $5 \mathrm{~mJ}$ de radiação UVC se mostraram inaplicáveis, uma vez que, as taxas de apoptose tardia (anexina $\mathrm{V}^{+} / 7 \mathrm{AAD}^{+}$) bem como de necrose $\left(7 \mathrm{AAD}^{+}\right)$aumentam significativamente nas células em cultura (dados não mostrados).

Dentre as diferentes condições testadas, a intensidade de $1 \mathrm{~mJ}$ de radiação UVC e $4 \mathrm{~h}$ de repouso foi a condição com maior porcentagem de apoptose celular. Neutrófiloslike não infectados sob essas condições apresentam aproximadamente 63\% das células apoptóticas em estágio de apoptose precoce (anexina $\mathrm{V}^{+} / 7 \mathrm{AAD}^{-}$) ou de apoptose tardia (anexina $\mathrm{V}^{+} / 7 \mathrm{AAD}^{+}$) (Figura $4 \mathrm{~A}$ ).

Neutrófilos-like infectados com $K$. pneumoniae apresentam uma taxa de aproximadamente de 50\% das células em processo de apoptose, enquanto neutrófilos- 
like infectados com S. pneumoniae apresentam, entre apoptose precoce e tardia, aproximadamente $76 \%$ das células em processo apoptótico (Figura 4B e C). 
Figura 4. Perfil de morte celular dos neutrófilos-like infectados ou não infectados após 1mJ de radiação UVC.

A)

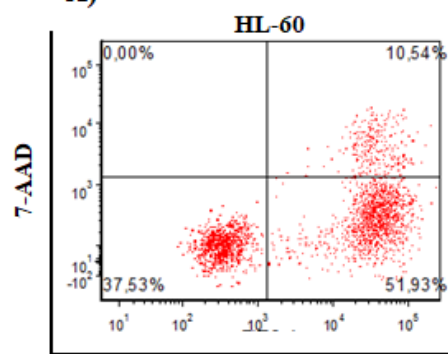

B) $\quad$ HL- $60+S p \quad$ C)

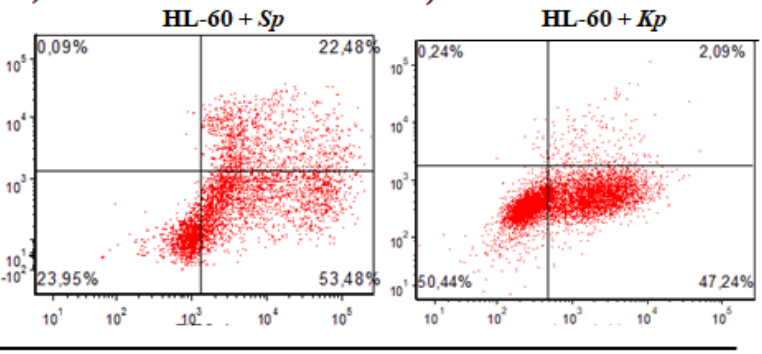

Anexina V

D)

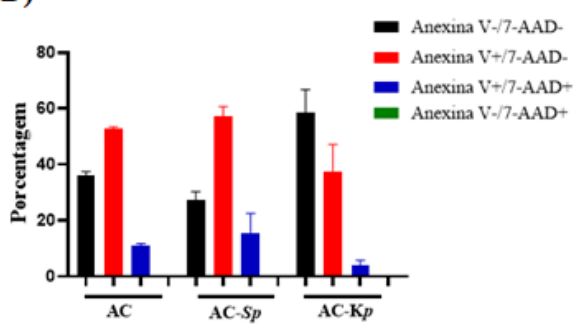

Os neutrófilos-like foram infectados ou não com S. pneumoniae ou $K$. pneumoniae, por $2 \mathrm{~h}$, e, após esse período, foram submetidos a $1 \mathrm{~mJ}$ de radiação UVC. Após 4 horas de repouso, as células foram analisadas por citometria de fluxo através da marcação de anexina $\mathrm{V}$ e 7AAD. A) Neutrófilos-like não infectados, B) Neutrófilos-like infectados por S. pneumoniae e C) Neutrófilos-like infectados por $K$. pneumoniae. D) Somatória das porcentagens de 3 experimentos realizados independentemente. Os resultados de A-C são referentes a um experimento representativo de três experimentos realizados individualmente. 


\subsection{Avaliação da porcentagem de eferocitose de macrófagos Mo}

A última etapa de padronização experimental foi determinar o melhor tempo de cocultura entre macrófagos M0 e as diferentes fontes de células apoptóticas para que obtivéssemos uma eficiente eferocitose. Por se tratar de um processo que ocorre rapidamente no nosso organismo (3), optamos por avaliar tempos curto de eferocitose. Os macrófagos M0 foram cultivados na presença de células apoptóticas estéreis (AC), células apoptóticas infectadas com $S$. pneumoniae (AC-Sp) e células apoptóticas infectadas com K. pneumoniae (AC-Kp) por 2 ou $4 \mathrm{~h}$.

Embora o MFI em macrófagos após a fagocitose de diferentes fontes de células apoptóticas apresente variações nos tempos de $2 \mathrm{~h}$ após a incubação (AC - 20242.1, AC$S p$ - 11448.6 e AC-Kp - 20676,9) e após 4h de incubação (AC - 23148.6, AC-Sp 13451.0 e AC-Kp - 19321.3), a porcentagem de macrófagos contendo células apoptóticas no seu interior (\% de células $\mathrm{CFSE}^{+}$) foi semelhante. Em todas as condições experimentais a porcentagem de eferocitose foi de aproximadamente 95\%, ou seja, quase a totalidade dos macrófagos M0 continham células apoptóticas em seu interior nos diferentes tempos analisados (Figura 5). Assim, optamos por realizar os experimentos subsequentes utilizando o tempo de $2 \mathrm{~h}$ de eferocitose. 
Figura 5. Porcentagem de eferocitose das diferentes fontes de células apoptóticas.

A)

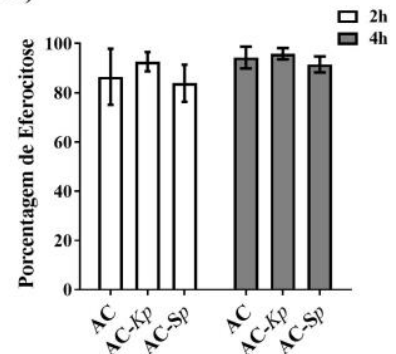

B)

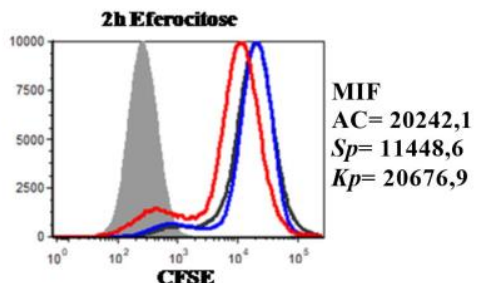

C)

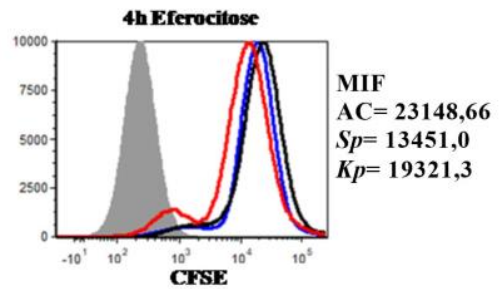

Os macrófagos M0 (histograma cinza) foram cultivados na presença de AC (linha preta), AC-Sp (linha vermelha) ou AC- $K p$ (linha azul) marcadas com $10 \mu \mathrm{M}$ de CFSE na proporção de 1 macrófagos para 3 células apoptóticas (1 M0:3 AC), por $2 \mathrm{~h}$ ou $4 \mathrm{~h}$. Após esse período, os macrófagos foram coletados e analisados por citometria de fluxo para a determinação do índice de eferocitose. A) Somatórias das replicatas experimentais no tempo de 2 e $4 \mathrm{~h}$. B) Média da intensidade de fluorescência (MFI) referente à eferocitose por $2 \mathrm{~h}$. C) MFI referente à eferocitose por $4 \mathrm{~h}$. Os resultados são referentes a um experimento representativo de dois experimentos realizados individualmente. 
5.4. Perfil de ativação de macrófagos M0 após a eferocitose de células apoptóticas estéreis ou infectadas com $S$. pneumoniae ou $K$. pneumoniae

Para determinar o efeito da eferocitose de células apoptóticas no perfil de ativação de macrófagos, macrófagos M0 foram incubados na presença de AC, AC-Sp e AC-Kp. Após $24 \mathrm{~h}$ de incubação, os macrófagos cultivados nas diferentes condições experimentais foram avaliados em relação à expressão de genes relacionados tanto ao perfil M1 quanto ao perfil M2.

Diferentemente do que esperávamos, a fagocitose de células apoptóticas estéreis não alterou o perfil de expressão dos genes analisados, Arg1, Fizz1, Cd206, Ccr7, quando comparados aos macrófagos M0 (Figura 6). Observamos também uma tendência à diminuição da expressão de $C d 86$ nessa condição experimental. Por outro lado, a eferocitose de AC-Sp por macrófagos M0 resultou no aumento da expressão de Fizzl e Ccr7 quando comparados aos macrófagos na ausência de AC ou aos macrófagos que eferocitaram AC. Além disso, também observamos uma tendência à diminuição da expressão de $C d 86$ e Argl quando comparado apenas aos macrófagos M0 (Figura 6). A eferocitose de $\mathrm{AC}-K p$ resultou em uma tendência à diminuição da expressão de $C d 206$ e uma tendência ao aumento da expressão de $C c r 7$ e $C d 86$ quando comparado aos macrófagos na ausência de AC e aos que fagocitaram AC (Figura 6).

Semelhante ao observado em relação à expressão gênica, a eferocitose de AC induziu um padrão de produção dos mediadores semelhante ao observado com macrófagos M0. Por outro lado, a eferocitose de AC-Sp induziu um aumento na produção de mediadores inflamatórios como IL-1 $\beta$ e óxido nítrico quando comparado aos macrófagos M0 ou àqueles que fagocitaram AC. Não foram observadas diferenças quanto à produção de TNF- $\alpha$ e IL-10 nessa condição experimental (Figura 6).

A eferocitose de AC- $K p$ induziu a liberação de altos níveis de mediadores inflamatórios, TNF- $\alpha$, IL-1 $\beta$ e óxido nítrico, quando comparado tanto à condição experimental contendo apenas macrófagos M0 na ausência ou presença de AC (Figura 6). Observamos também uma tendência ao aumento na produção de IL-10 nessa condição experimental. 
Figura 6. Perfil de expressão gênica e mediadores secretados por macrófagos após a eferocitose de AC, AC-Sp ou AC-Kp.

A)

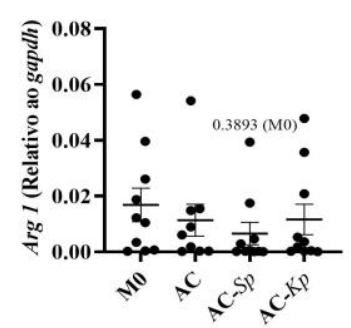

E)

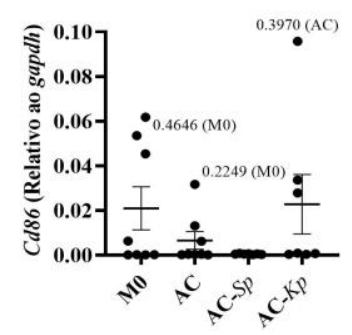

I)

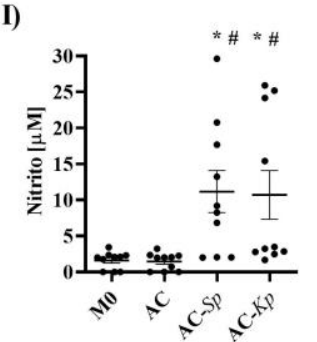

C)

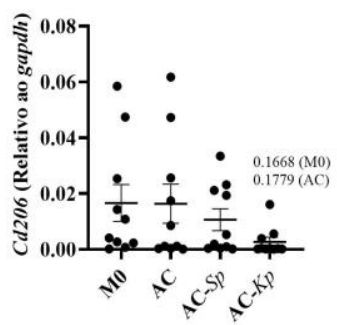

G)

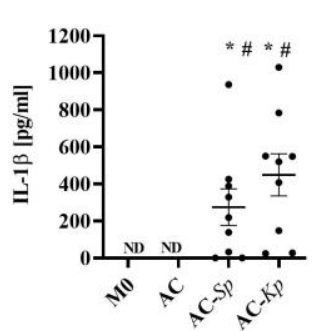

D)

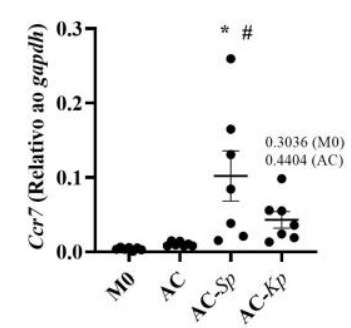

H)

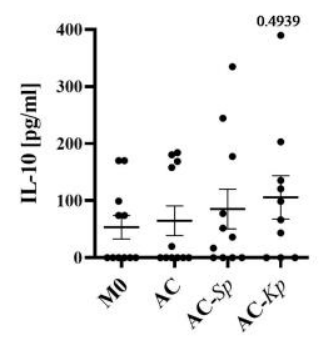

J)

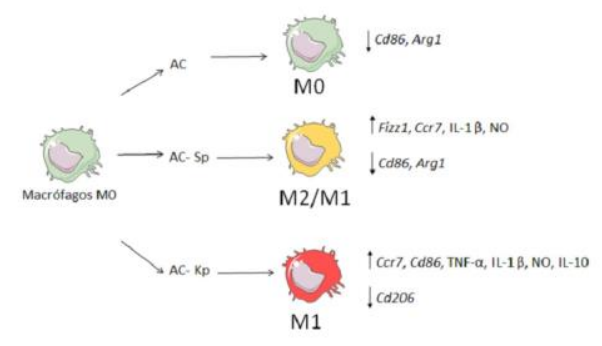

Os macrófagos M0 foram cocultivados com AC, AC-Sp ou AC-Kp na proporção de 1 macrófago para $3 \mathrm{AC}$ (1M0: $3 \mathrm{AC}$ ), por $2 \mathrm{~h}$. Em seguida, a cultura foi lavada e incubada com meio novo por subsequentes $24 \mathrm{~h}$. Após esse período as células foram coletadas e a expressão dos genes foi analisa. A) $A r g 1$, B) $F i z z 1$, C) $C d 206$, D) $C c r 7$ e E) $C d 86$. Os sobrenadantes das culturas celulares foram coletados e avaliados quanto à presença dos diferentes mediadores. F) TNF- $\alpha$, G) IL-1 $\beta, \mathbf{H})$ IL-10, I) NO e J) Esquema representativo do perfil de polarização observado nos gráficos A-I; macrófagos M0: verde, macrófagos M1: vermelho e macrófagos com perfil misto: amarelo. Resultados de F-H foram expressos em $\mathrm{pg} / \mathrm{mL}$ e os resultados de I foram expressos em $\mu \mathrm{M}$. Média \pm SEM da quantificação referente a 4-10 experimentos realizados individualmente sem replicatas experimentais. ${ }^{*} \mathrm{p}<0,05$ vs $\mathrm{M} 0, \# \mathrm{p}<0,05$ vs AC e $\& \mathrm{p}<0,05$ vs AC-Sp. Valores de p entre 0,5 e 0,05 estão sinalizados no gráfico. 


\subsection{Participação de receptores do tipo Toll no perfil de ativação de macrófagos}

M0 após a eferocitose de células apoptóticas estéreis ou infectadas com $S$. pneumoniae ou K. pneumoniae

TLR2 e TLR4 são receptores descritos no reconhecimento tanto de $S$. pneumoniae (44, 90) como de $K$. pneumoniae (91). Além disso, prévios estudos demonstraram que esses receptores podem ser translocados para o fagossomo durante o processo de eferocitose onde desempenham suas funções de reconhecimento de PAMPs e ativação das vias de sinalizações aos quais estão acoplados $(92,93)$. Nesse trabalho, avaliamos a participação desses dois receptores no processo de ativação de macrófagos após a eferocitose de células apoptóticas estéreis ou células apoptóticas infectadas com as duas cepas bacterianas citadas.

A ausência dos receptores TLR2 durante o processo de eferocitose de AC, de maneira geral, não alterou o perfil de expressão dos genes relacionados tanto ao perfil M1 ( $C$ cr7 e $C d 86$ ) em macrófagos quando comparado aos macrófagos M0 oriundos de animais WT que fagocitaram AC (Figura 7). Observamos também um modesto aumento da expressão de Arg1 e uma diminuição da expressão de Fizzl. Por outro lado, a ausência de TLR4 durante o processo de eferocitose de AC resultou em uma tendência ao aumento da expressão de $C d 206$, $C c r 7$ e $C d 86$ quando comparado aos macrófagos M0 oriundos de animais WT que fagocitaram AC (Figura 7).

A avaliação dos mediadores liberados no sobrenadante da cultura de macrófagos deficientes para os receptores TLR2 e TLR4 após eferocitose de AC não indicou alteração no perfil de mediadores secretados. Não foi detectada diferenças quanto à produção de TNF- $\alpha$, IL-10 e NO em nenhuma das condições avaliadas. Corroborando aos resultados anteriores, não foi detectado IL-1 $\beta$ nas condições citadas acima (Figura 7). 
Figura 7. Perfil de expressão gênica e de mediadores secretados por macrófagos deficientes de TLR2 ou TLR4 após a eferocitose de células apoptóticas estéreis.

A)

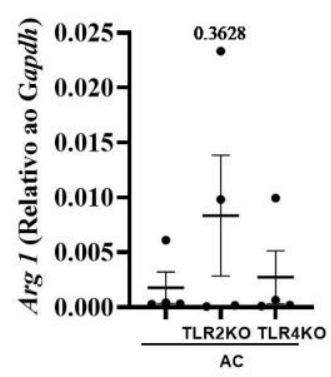

D)

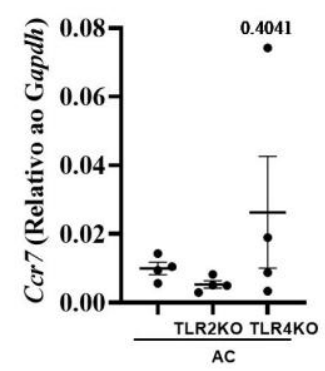

G)

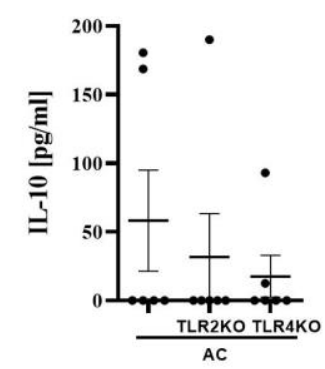

B)

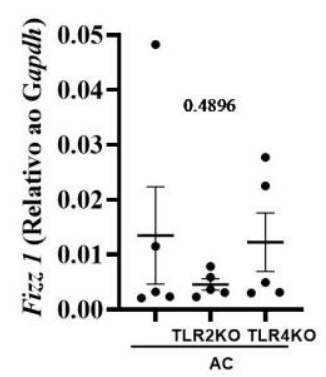

E)

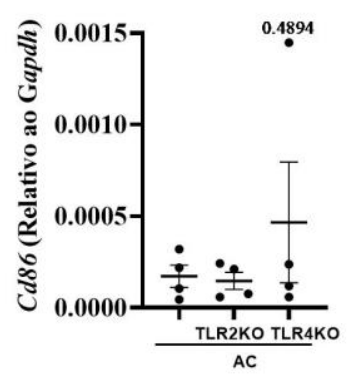

H)

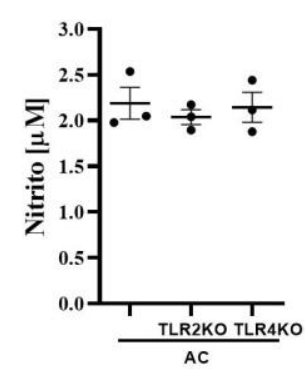

C)

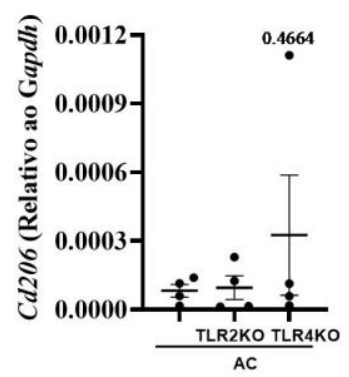

F)

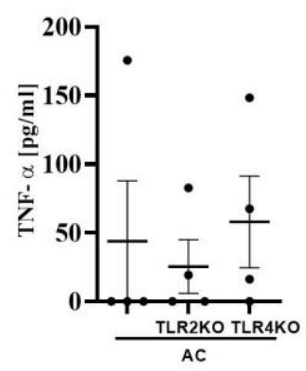

I)

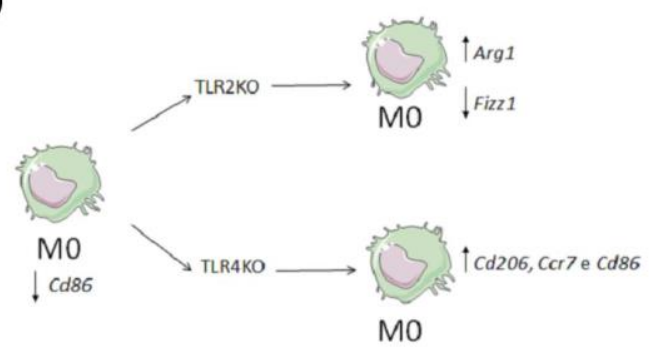

Os macrófagos M0 oriundos de camundongos selvagens, camundongos deficientes para TLR2 (TLR2KO) ou camundongos deficientes para TLR4 (TLR4KO) foram cocultivados com células apoptóticas estéreis na proporção 1 macrófago M0 a cada $3 \mathrm{AC}$, por $2 \mathrm{~h}$. Em seguida, a cultura foi lavada e incubada com meio novo por subsequentes 24h. Após esse período, as células foram coletadas e a expressão dos genes foi analisada. A) Arg1, B) Fizzl, C) Cd206, D) Ccr7 e E) $C d 86$. Os sobrenadantes das culturas celulares foram coletados e avaliados quanto à presença de diferentes mediadores. F) TNF- $\alpha, \mathbf{G})$ IL-10, H) NO e I) Esquema representativo do perfil de polarização observado nos gráficos A-H; macrófagos M0: verde. Resultados de $\mathrm{F}$ e $\mathrm{G}$ foram expressos em $\mathrm{pg} / \mathrm{mL}$ e os resultados de $\mathrm{H}$ foram expressos em $\mu \mathrm{M}$. Média $\pm \mathrm{SEM}$ da quantificação de 4-6 experimentos realizados individualmente. Valores de p entre 0,5 e 0,05 estão sinalizados no gráfico. 
A eferocitose de AC-Sp por macrófagos de animais deficientes para o receptor TLR2 ou deficientes para o receptor TLR4 não induziu diferenças estatisticamente significativas na expressão dos genes avaliados (Fizz1, Ccr7 e Cd86) quando comparado aos macrófagos oriundos de animais selvagens após a eferocitose de AC-Sp. Houve um modesto aumento na expressão de $\operatorname{Argl}$ e uma tendência à diminuição da expressão de $C d 206$ em macrófagos deficientes para o receptor TLR2 (Figura 8).

Dentre os mediadores avaliados no sobrenadante de cultura, a eferocitose de AC-Sp não induziu alteração no perfil de citocinas liberadas por macrófagos deficientes tanto para TLR2 quando comparado aos oriundos de animais WT. Por outro lado, a eferocitose de AC-Sp por macrófagos deficientes de TLR4 induziu uma tendência a aumento na liberação de IL-1 $\beta$ quando comparamos aos oriundos de animais WT que eferocitam AC-Sp (Figura 8). 
Figura 8. Perfil de expressão gênica e mediadores secretados por macrófagos deficientes de TLRs após a eferocitose de células apoptóticas infectadas com $S$. pneumoniae.

A)

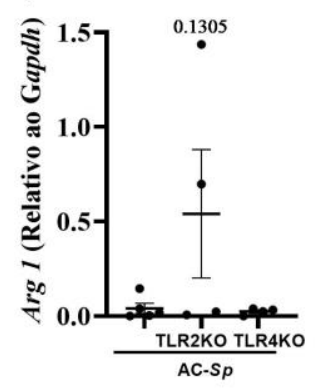

E)

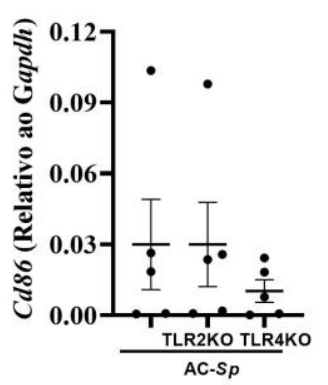

B)

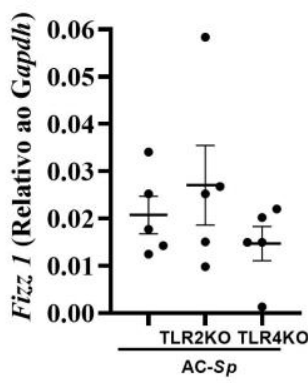

F)

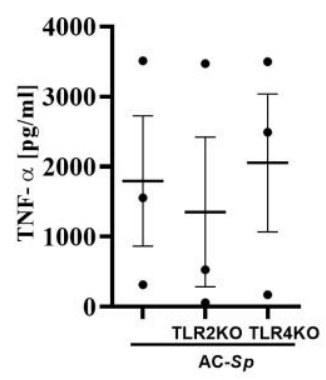

C)

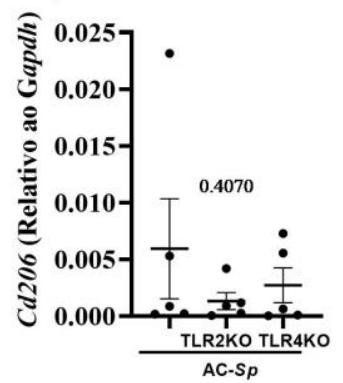

G)

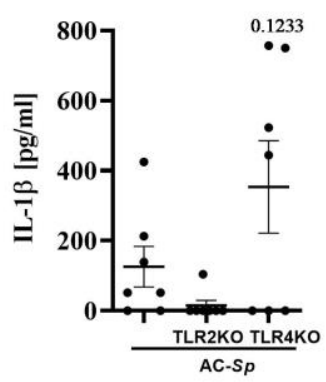

D)

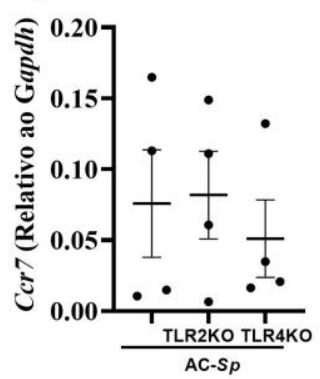

H)

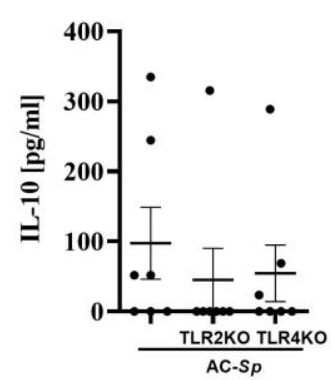

I)

J)
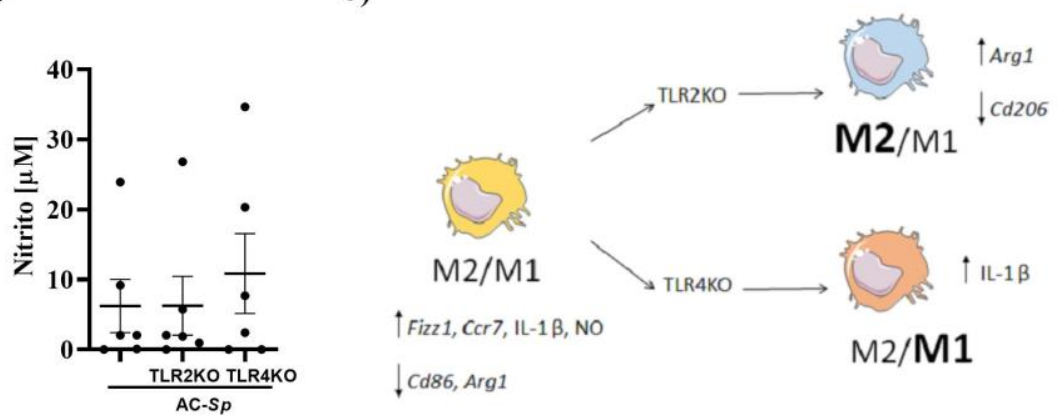

Os macrófagos M0 oriundos de camundongos selvagens, camundongos deficientes para TLR2 (TLR2KO) ou camundongos deficientes para TLR4 (TLR4KO) foram cocultivados com AC-Sp na proporção 1 macrófago M0 a cada $3 \mathrm{AC}-S p$, por $2 \mathrm{~h}$. Em seguida, a cultura foi lavada e encubada com meio novo por subsequentes $24 \mathrm{~h}$. Após esse período as células foram coletadas e a expressão dos genes foi analisada. A) Arg1, B) Fizz1, C) $C d 206$, D) $C c r 7$ e E) $C d 86$. Os sobrenadantes de cultura foram coletados e avaliados quanto à presença de diferentes mediadores. F) TNF- $\alpha$, G) IL-1 $\beta$, H) IL-10, I) NO e J) Esquema representativo do perfil de polarização observado nos gráficos A-I; macrófagos com perfil misto: amarelo, macrófagos com perfil misto dirigindo-se ao perfil M2: azul claro e macrófagos com perfil misto dirigindo-se ao perfil M1: laranja. Resultados de A-H são expressos em $\mathrm{pg} / \mathrm{mL}$ e o resultado de I é expresso em $\mu \mathrm{M}$. Média \pm SEM da quantificação referente a 3-7 experimentos realizados individualmente sem replicatas experimentais. Valores de p entre 0,5 e 0,05 estão sinalizados no gráfico. 
Quando avaliamos o perfil gênico de macrófagos deficiente de TLR2 e TLR4 que eferocitam AC- $K p$ notamos uma tendência ao aumento da expressão de $C d 206$ em células deficientes para o receptor TLR2 e uma tendência à diminuição na expressão de $C c r 7$ quando AC- $K p$ foram fagocitadas por macrófagos deficientes de TLR4 comparado aos macrófagos M0 selvagens que fagocitaram AC- $K p$ (Figura 9). Não foram observadas modulações no perfil dos outros genes avaliados (Arg1, Fizzle Cd86).

A deficiência dos receptores TLR2 em macrófagos M0 que fagocitam AC- $K p$ resultou em uma tendência à diminuição da produção de IL-10 e aumento da liberação de TNF- $\alpha$ quando comparados a eferocitose de AC- $K p$ por macrófagos M0 oriundos de animais selvagens. Da mesma forma, a deficiência de TLR4 em macrófagos provocou uma tendência à diminuição na produção das citocinas IL-10 e IL-1 $\beta$ quando comparado à condição de macrófagos M0 oriundos de animais selvagens (Figura 9). 
Figura 9. Perfil de expressão gênica e mediadores secretados por macrófagos deficientes de TLRs após a eferocitose de células apoptóticas infectadas com $K$. pneumoniae.

A)

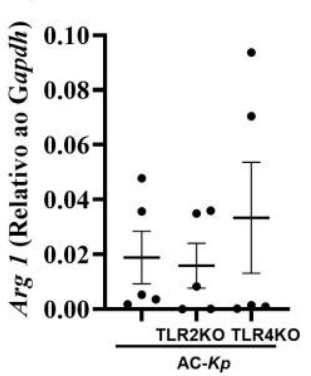

E)

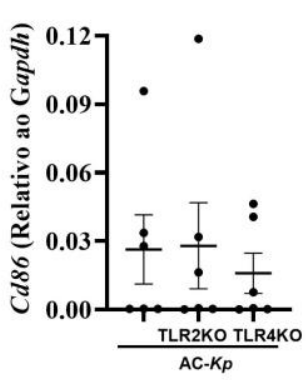

B)

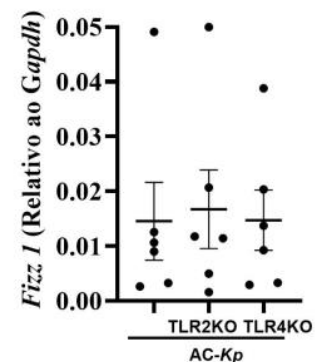

F)

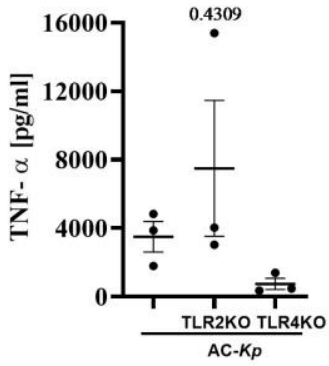

C)

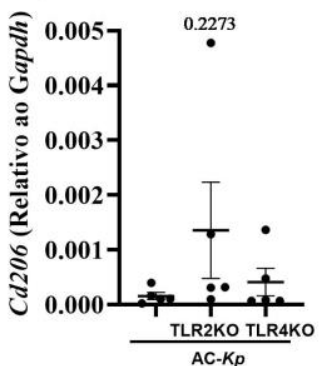

G)

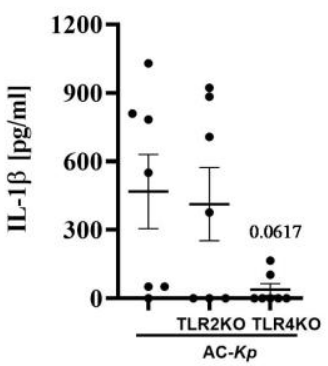

D)

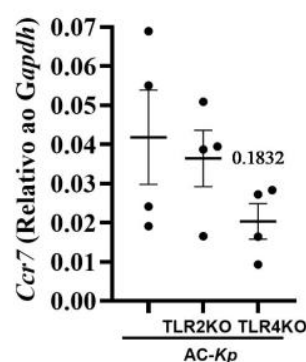

H)

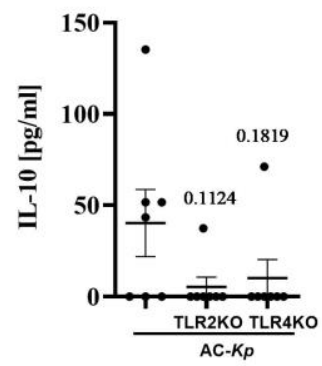

I)

J)
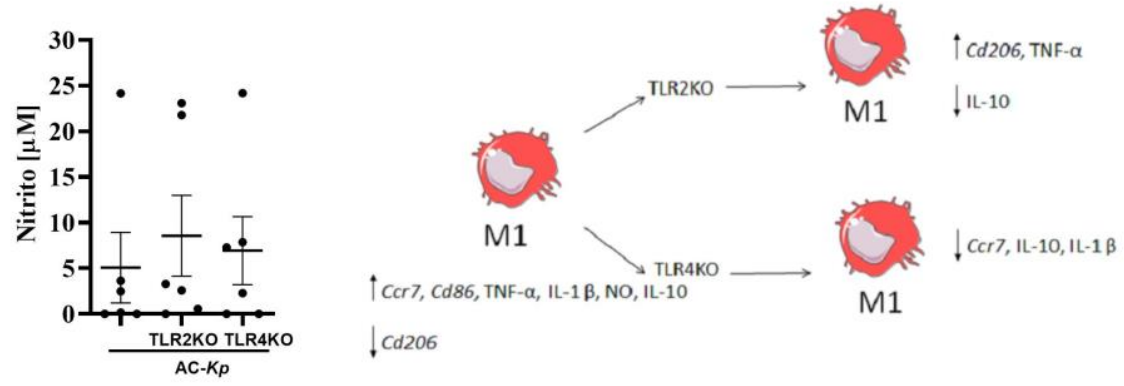

Os macrófagos M0 oriundos de camundongos selvagens, camundongos deficientes para TLR2 ou camundongos deficientes para TLR4 foram cocultivados com AC-Kp na proporção 1 macrófago M0 a cada 3 AC-Kp, por $2 \mathrm{~h}$. Em seguida, a cultura foi lavada e incubada com meio novo por subsequentes $24 \mathrm{~h}$. Após esse período, as células foram coletadas e a expressão dos genes foi analisada. A) $A r g 1$, B) Fizz1, C) $C d 206$, D) $C c r 7$ e E) $C d 86$. Os sobrenadantes de cultura foram coletados e avaliados quanto à presença de diferentes mediadores. F) TNF- $\alpha, \mathbf{G}$ ) IL-1 $\beta$, H) IL-10, I) NO e J) Esquema representativo do perfil de polarização observado nos gráficos A-I; macrófagos M1: vermelho. Resultados de F-H são expressos em pg/mL e o resultado de I é expresso em $\mu \mathrm{M}$. Média \pm SEM da quantificação referente a 4-6 experimentos realizados individualmente sem replicatas experimentais. Valores de p entre 0,5 e 0,05 estão sinalizados no gráfico 
5.6. Participação do fator de transcrição NF-אB no perfil de ativação de macrófagos M0 após a eferocitose de células apoptóticas estéreis ou células apoptóticas infectadas com S. pneumoniae ou K. pneumoniae

Além de receptores de superfície, diferentes moléculas adaptadoras e fatores de

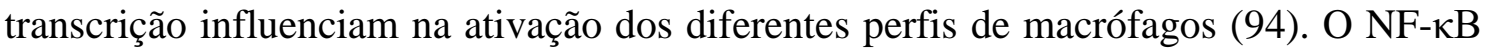
é um importante fator de transcrição envolvido diretamente na produção de citocinas por macrófagos (95). Dessa forma, avaliamos o evolvimento dessa molécula na ativação de macrófagos durante aeferocitose de AC, AC-Sp e AC-Kp.

Diversas concentrações do inibidor de NF-אB foram testadas $(5,10$ e $25 \mu \mathrm{M})$, entretanto, as concentrações de 10 e $25 \mu \mathrm{M}$ mostraram-se tóxicas, uma vez que diminuíram a viabilidade celular da cultura após o tratamento (dados não mostrados). Assim, a concentração de $5 \mu \mathrm{M}$ foi utilizada para os subsequentes experimentos.

Macrófagos M0 que eferocitam AC na presença do inibidor apresentaram um aumento expressão de Argl e Cd86. Observamos, também, uma tendência ao aumento da expressão da molécula de Fizzl e Cd206 na presença do inibidor quando comparado a macrófagos M0 na ausência do tratamento. Não foram observadas diferenças na

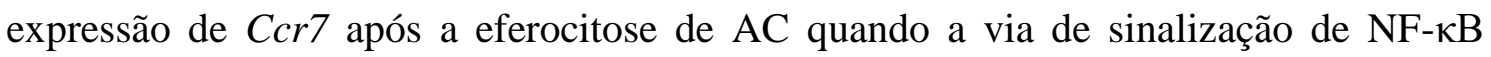
estava inibida (Figura 10).

A avaliação do perfil de mediadores liberados após a eferocitose de $\mathrm{AC}$ na

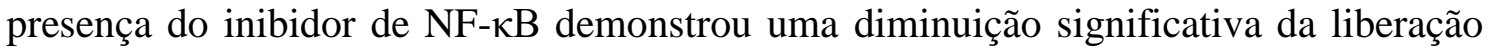
de IL-10 e uma modesta diminuição na produção de TNF- $\alpha$. Além disso, houve uma tendência ao aumento na liberação de óxido nítrico, quando comparamos aos macrófagos M0 que eferocitaram AC na ausência do inibidor de NF- $\kappa$ B. Corroborando aos dados já obtidos, não foi detectada a presença de IL-1 $\beta$ nessa condição experimental (Figura 10). 
Figura 10. Perfil de expressão gênica e mediadores secretados por macrófagos tratados com inibidor de NF-kB após a eferocitose de células apoptóticas estéreis.

A)

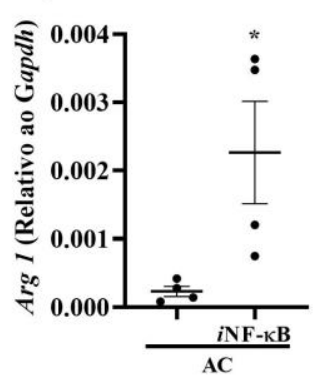

D)

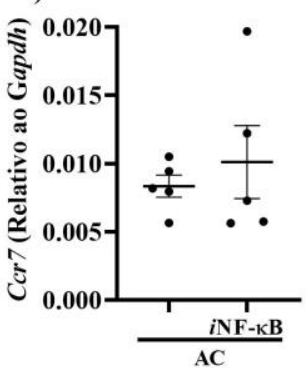

G)

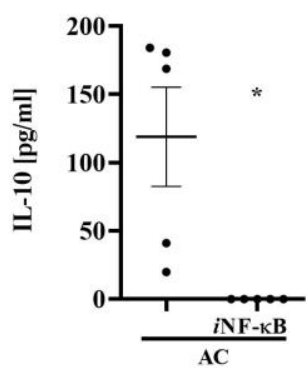

B)

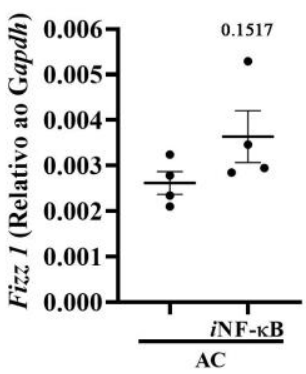

E)

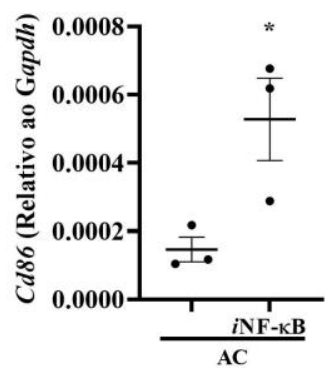

H)

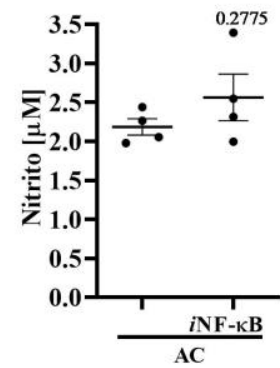

C)

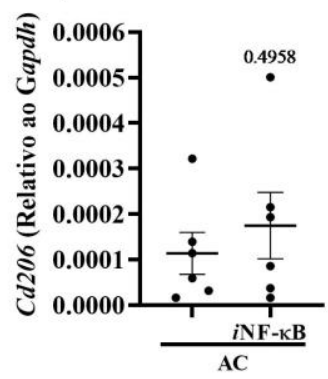

F)

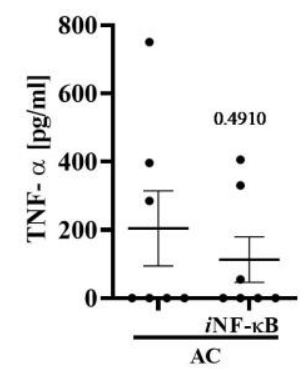

I)

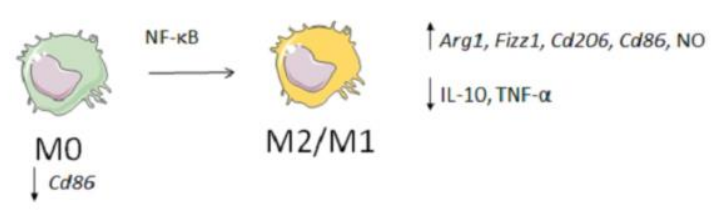

Macrófagos M0 foram tratados com inibidor de NF-kB $(5 \mu \mathrm{M})$ por 30 minutos. Após esse período, as células foram cultivadas na presença de AC na proporção 1 macrófago M0 a cada 3 $\mathrm{AC}$, por $2 \mathrm{~h}$. Em seguida, a cultura foi lavada e incubada com meio novo por subsequentes $24 \mathrm{~h}$. Após esse período, as células foram coletadas e a expressão dos genes foi analisada. A) Argl, B) Fizzl, C) $C d 206$, D) $C c r 7$ e E) $C d 86$. Os sobrenadantes de cultura foram coletados e avaliados quanto à presença de diferentes mediadores. F) TNF- $\alpha$, G) $\mathrm{IL}-10$, H) $\mathrm{NO}$ e I) Esquema representativo do perfil de polarização observado nos gráficos $\mathrm{A}-\mathrm{H}$; macrófagos $\mathrm{M} 0$ : verde e macrófagos com perfil misto: amarelo. Resultados de $\mathrm{F}$ e $\mathrm{G}$ são expressos em pg/mL e o resultado de $\mathrm{H}$ é expresso em $\mu \mathrm{M}$. Média \pm SEM da quantificação referente a 4-7 experimentos realizados individualmente sem replicatas experimentais. ${ }^{*} \mathrm{p}<0,05$ vs $\mathrm{M} 0+\mathrm{AC}$. Valores de $\mathrm{p}$ entre 0,5 e 0,05 estão sinalizados no gráfico. 
Por outro lado, a eferocitose de AC-Sp por macrófagos M0 induziu um aumento na expressão de $C d 86$ e uma tendência ao aumento da expressão de Argl e Cd206 quando comparado aos macrófagos M0 que eferocitaram AC-Sp na ausência do inibidor de NF-кB (Figura 11). Não observamos diferenças na expressão de Ccr7 e Fizz1 nessa condição experimental.

Somado a isso, observamos uma tendência à diminuição da produção de TNF- $\alpha$ por macrófagos tratados com o inibidor de NF- $\mathrm{BB}$ após a eferocitose de AC-Sp quando comparado aos macrófagos que eferocitaram AC-Sp sem a presença do tratamento com

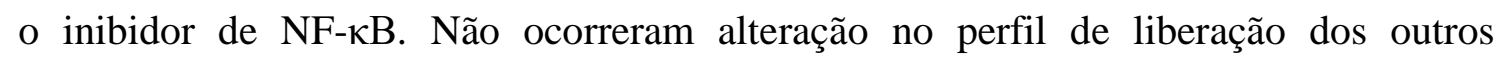
mediadores avaliados (Figura 11). 
Figura 11. Perfil de expressão gênica e mediadores secretados por macrófagos tratados com inibidor de NF-кB após a eferocitose de células apoptóticas infectadas com $S$. pneumoniae.

A)

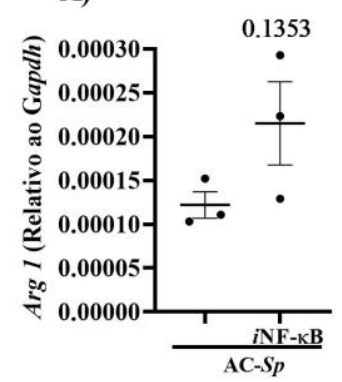

E)

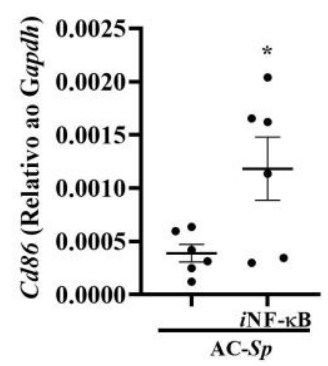

I)

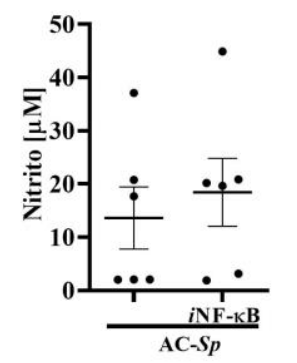

C)

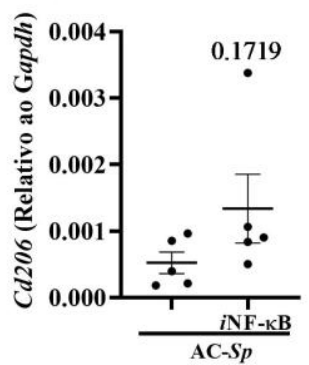

G)

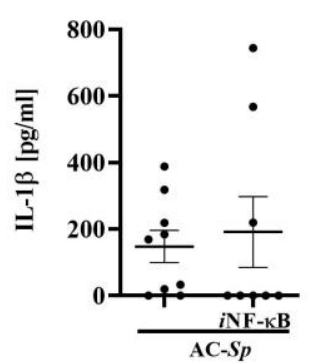

J)

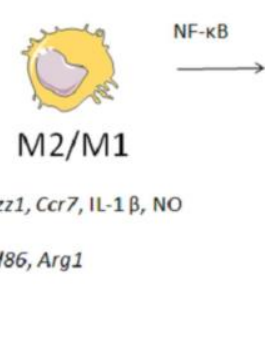

D)

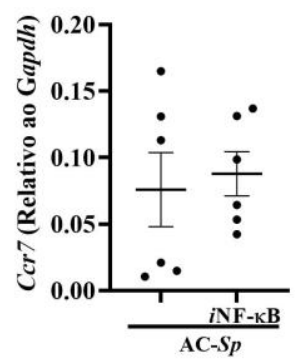

H)

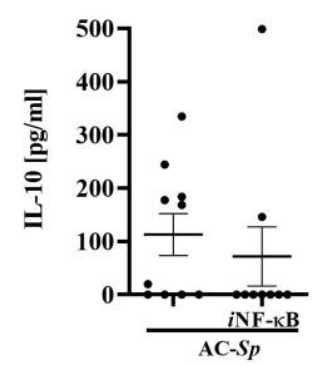

$\mathrm{M} 2 / \mathrm{M} 1$

Os macrófagos M0 foram tratados com inibidor de NF- $\mathrm{BB}(5 \mu \mathrm{M})$ por 30 minutos. Após esse período, as células foram cultivadas na presença de AC-Sp na proporção 1 macrófago M0 a cada $3 \mathrm{AC}-\mathrm{Sp}$, por $2 \mathrm{~h}$. Em seguida, a cultura foi lavada e incubada com meio novo por subsequentes 24h. Após esse período as células foram coletadas e a expressão dos genes foi analisada. A) Argl, B) Fizz1, C) Cd206, D) $C c r 7$ e E) Cd86. Os sobrenadantes de cultura foram coletados e avaliados quanto à presença de diferentes mediadores. F) TNF- $\alpha$, G) IL-1 $\beta$, H) IL-10, I) NO e J) Esquema representativo do perfil de polarização observado nos gráficos A-I; macrófagos com perfil misto: amarelo e macrófagos com perfil misto dirigindo-se ao perfil M2: azul claro. Resultados de F-H são expressos em $\mathrm{pg} / \mathrm{mL}$ e o resultado de I é expresso em $\mu \mathrm{M}$. Média $\pm \mathrm{SEM}$ da quantificação referente a 3-10 experimentos realizados individualmente sem replicatas experimentais. ${ }^{*} \mathrm{p}<0,05$ vs $\mathrm{M} 0+\mathrm{AC}-\mathrm{Sp}$. Valores de $\mathrm{p}$ entre 0,5 e 0,05 estão sinalizados no gráfico. 


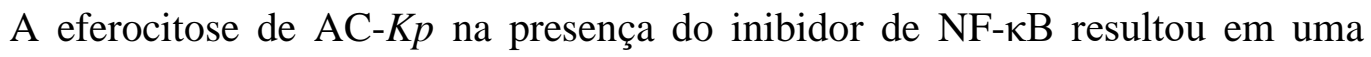
diminuição na expressão de Cd206 em macrófagos (Figura 12). Além disso, observamos uma tendência à diminuição da expressão de Fizzl, Argl e Ccr7 em macrófagos M0 que eferocitaram $\mathrm{AC}-K p$ na presença do inibidor de NF- $\mathrm{B}$ quando comparado aos macrófagos M0 que eferocitaram AC-Kp na ausência do tratamento farmacológico com o inibidor. Não foram observadas mudanças no perfil de expressão de $C d 86$ para esta condição experimental.

$\mathrm{O}$ tratamento com o inibidor de NF- $\kappa \mathrm{B}$ em macrófagos que fagocitaram $\mathrm{AC}-K p$ promoveu uma diminuição na liberação de IL-1 $\beta$ quando comparado aos macrófagos M0 que fagocitaram AC-Kp sem a inibição dessa via de sinalização (Figura 12). Não observamos diferenças na produção de TNF- $\alpha$, IL-10 e NO entre macrófagos M0 que

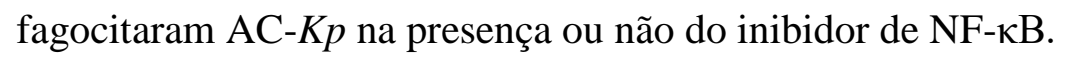


Figura 12. Perfil de expressão gênica e de mediadores secretados por macrófagos tratados com inibidor de NF-кB após a eferocitose de células apoptóticas infectadas com $K$. pneumoniae.

A)

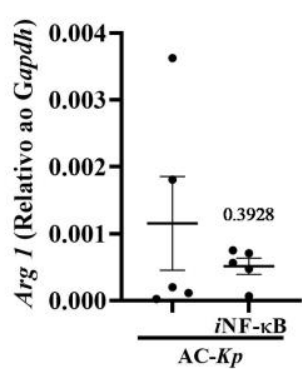

E)

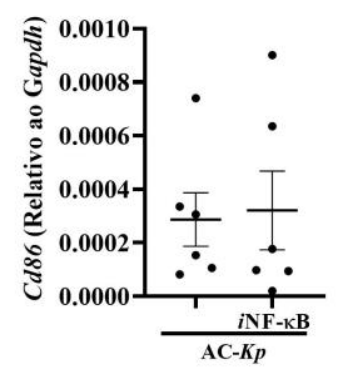

I)
B)

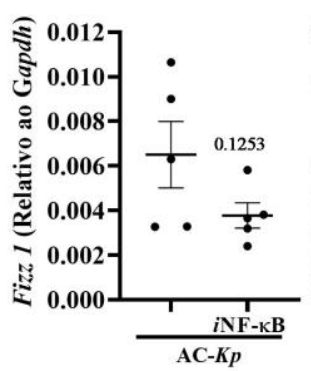

F)
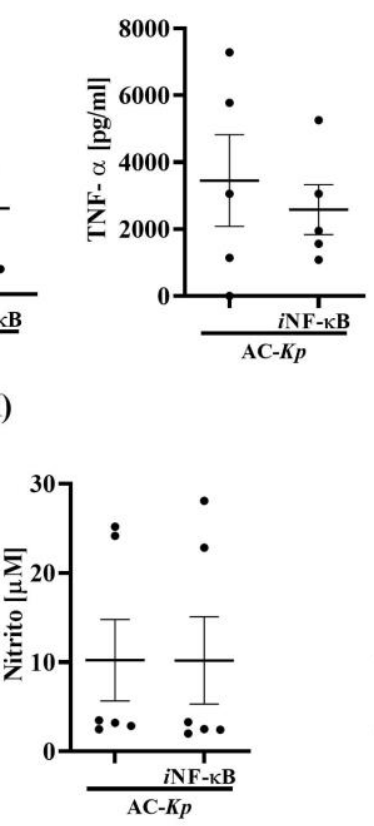

C)

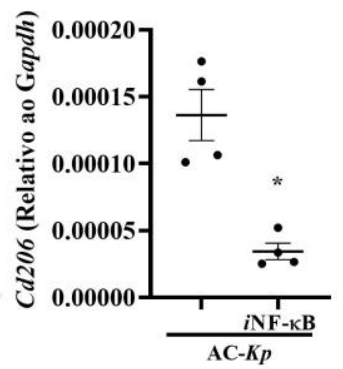

G)

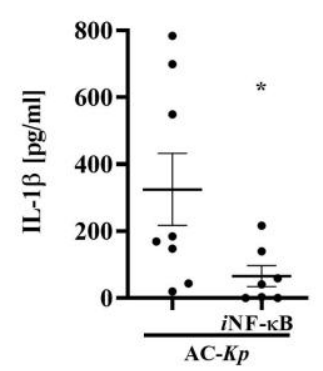

J)

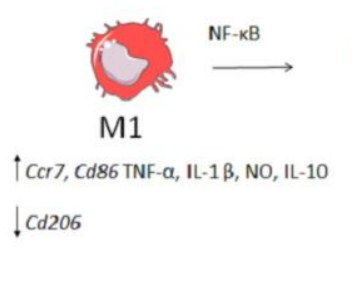

D)

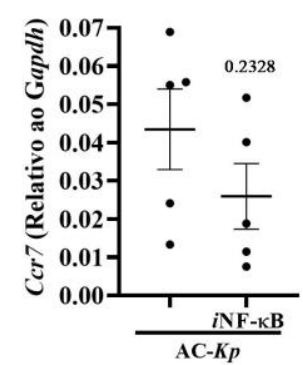

H)

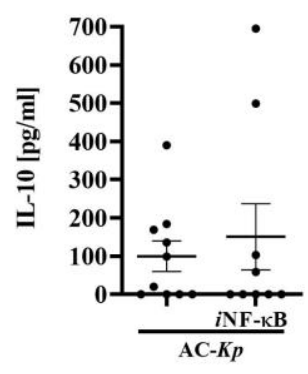

\section{$\mathrm{M} 2 / \mathrm{M} 1$}

Os macrófagos M0 foram tratados com inibidor de NF- $\kappa \mathrm{B}(5 \mu \mathrm{M})$ por 30 minutos. Após esse período, as células foram cultivadas na presença de $\mathrm{AC}-K p$ na proporção 1 macrófago M0 a cada 3 AC- $K p$, por $2 \mathrm{~h}$. Em seguida, a cultura foi lavada e incubada com meio novo por subsequentes $24 \mathrm{~h}$. Após esse período as células foram coletadas e a expressão dos genes foi analisada. A) $\mathrm{Arg} 1$, B) $F i z z 1$, C) $C d 206$, D) $C c r 7$ e E) $C d 86$. Os sobrenadantes de cultura foram coletados e avaliados quanto à presença de diferentes mediadores. F) TNF- $\alpha$, G) IL- $1 \beta$, H) IL10, I) $\mathrm{NO}$ e J) Esquema representativo do perfil de polarização observado nos gráficos A-I; macrófagos M1: vermelho e macrófagos com perfil misto dirigindo-se ao perfil M1: laranja. Resultados de F-H são expressos em $\mathrm{pg} / \mathrm{mL}$ e o resultado de I é expresso em $\mu \mathrm{M}$. Média $\pm \mathrm{SEM}$ da quantificação referente a 3-10 experimentos realizados individualmente sem replicatas experimentais. ${ }^{*} \mathrm{p}<0,05$ vs $\mathrm{M} 0+\mathrm{AC}-K p$. Valores de $\mathrm{p}$ entre 0,5 e 0,05 estão sinalizados no gráfico. 
5.7. Envolvimento dos fatores de transcrição STAT1 e STAT3 no perfil de ativação de macrófagos M0 após a eferocitose de células apoptóticas estéreis ou células apoptóticas infectadas com $S$. pneumoniae ou $K$. pneumoniae

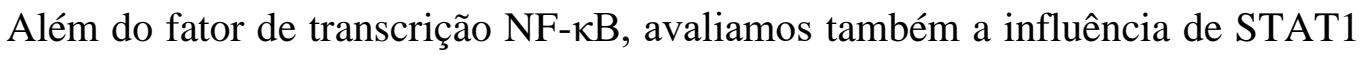
e STAT3, uma vez que esses são fatores de transcrição sabidamente envolvidos na polarização de macrófagos para o perfil de ativação M1 (96) e M2 (97). Lawrence e Kornblunth demonstraram que a infecção causada por $S$. pneumoniae induz a ativação tanto de STAT1 como de STAT3 no ambiente pulmonar (98). Além disso, animais deficientes de STAT1 são mais susceptíveis a infecções causadas por esse patógeno (99). Por outro lado, o bloqueio de STAT1 durante a infecção por K. pneumoniae favoreceu a resolução da infecção, associado a liberação de IL-10, ativação de STAT3, e o aumento da eferocitose de neutrófilos apoptóticos no pulmão dos animais (100).

As concentrações dos inibidores de STAT1 e STAT3 de10, 20 e 30 $\mu \mathrm{M}$, foram testadas para todas as condições experimentais (AC, AC-Sp e AC-Kp), mas estas se mostraram tóxicas, uma vez que diminuíram a viabilidade celular (dados não mostrados). Dessa forma, as concentrações utilizadas nos experimentos subsequentes foram 1 e $0,1 \mu \mathrm{M}$.

O tratamento com o inibidor do fator de transcrição STAT1 não alterou o perfil dos genes M1/M2 (Fizz1, Cd206, Ccr7 e Cd86) expressos por macrófagos M0 após eferocitose de AC. Observamos apenas uma tendência ao aumento da expressão de Argl quando a cultura celular foi tratada com $1 \mu \mathrm{M}$ do inibidor de STAT1 (Figura 13). A eferocitose de AC por macrófagos M0 na presença do inibidor de STAT3 resultou em um aumento da expressão de Cd206 quando comparado aos macrófagos M0 que fagocitaram AC na ausência de inibição farmacológica da via de STAT3. Não foram observadas alteração na expressão dos outros genes avaliados, sejam eles relacionados ao perfil M1, $C c r 7$ e $C d 86$, ou genes relacionados ao perfil M2, Argl e Fizzl (Figura 13).

A presença do inibidor de STAT1 na concentração de $1 \mu \mathrm{M}$ durante a eferocitose de AC resultou na produção de TNF- $\alpha$ por esses macrófagos quando comparamos aos macrófagos M0 que fagocitaram AC sem a inibição dos fatores de transcrição (Figura 13). O tratamento com os inibidores de STAT1 e STAT3, nas duas concentrações 
avaliadas, foi capaz de inibir a liberação de IL-10 por macrófagos que fagocitaram AC quando comparado aos macrófagos M0 não tratados (Figura 13). Observamos uma tendência à diminuição da produção de óxido nítrico em macrófagos que eferocitaram AC na presença dos inibidores de $0,1 \mu \mathrm{M}$ de STAT3 quando comparado aos macrófagos que não receberam bloqueio farmacológico (Figura 13). 
Figura 13. Perfil de expressão gênica e mediadores secretados por macrófagos tratados com inibidores de STAT após a eferocitose de células apoptóticas estéreis.

A)

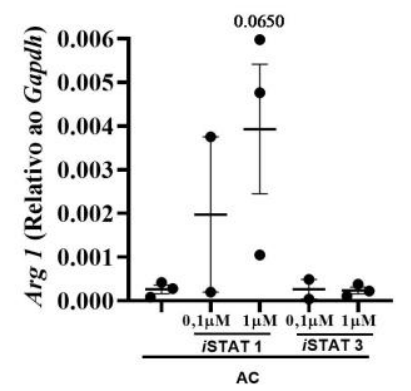

D)

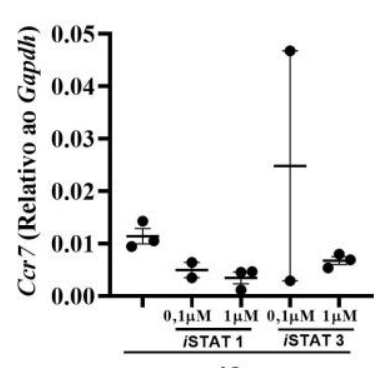

G)

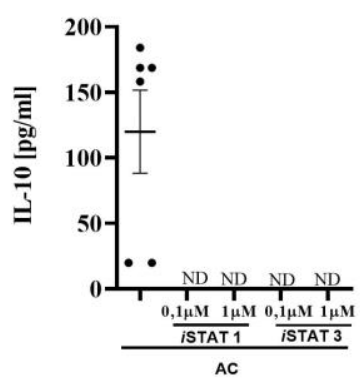

B)

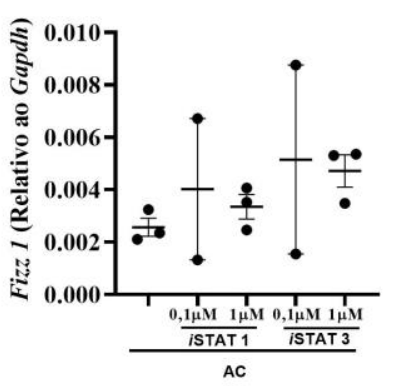

E)

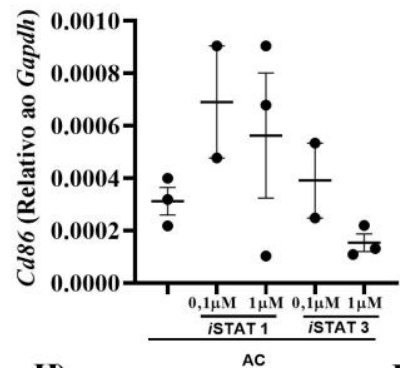

H)

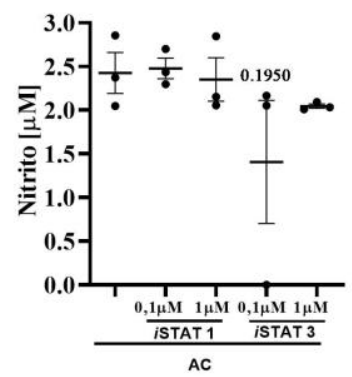

C)

F)
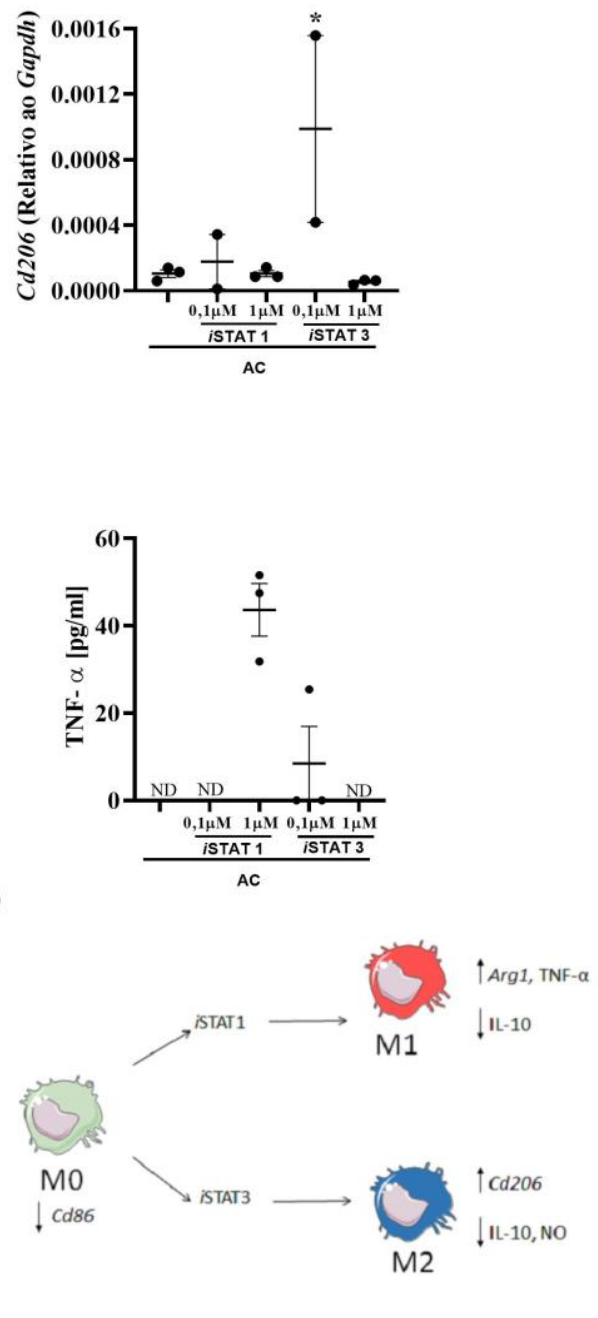

Os macrófagos M0 foram tratados com inibidor de STAT1 e STAT3 $(0,1$ e $1 \mu \mathrm{M})$ por 30 minutos. Após esse período, as células foram cultivadas na presença de $\mathrm{AC}$ na proporção 1 macrófago M0 a cada $3 \mathrm{AC}$, por $2 \mathrm{~h}$. Em seguida, a cultura foi lavada e incubada com meio novo por subsequentes $24 \mathrm{~h}$. Após esse período as células foram coletadas e a expressão dos genes foi analisada. A) Argl, B) Fizz1, C) $C d 206$, D) $C c r 7$ e E) $C d 86$. Os sobrenadantes de cultura foram coletados e avaliados quanto à presença de diferentes mediadores. F) TNF- $\alpha$, G) IL-10, H) NO e I) Esquema representativo do perfil de polarização observado nos gráficos $\mathrm{A}-\mathrm{H}$; macrófagos M0: verde, macrófagos M1: vermelho e macrófagos M2: azul. Resultados de F e G são expressos em $\mathrm{pg} / \mathrm{mL}$ e o resultado de $\mathrm{H}$ é expresso em $\mu \mathrm{M}$. Média $\pm \mathrm{SEM}$ da quantificação referente a 2-5 experimentos realizados individualmente sem replicatas experimentais. ${ }^{*} \mathrm{p}<0,05$ vs M0+AC. Valores de p entre 0,5 e 0,05 estão sinalizados no gráfico. 
De maneira geral, quando analisamos o impacto da presença dos inibidores de STAT1/3 durante a eferocitose de AC-Sp por macrófagos M0, observamos a inibição da expressão gênica de marcadores relacionados tanto ao perfil de ativação M1 quanto M2. A presença do inibidor de STAT1 na menor concentração resultou em uma menor expressão de Fizzle $C d 86$ e uma tendência à diminuição da expressão de $C d 206, \operatorname{Arg} 1$ e Ccr7 em macrófagos M0 que eferocitaram AC-Sp, quando comparado aos macrófagos que não receberam o tratamento farmacológico (Figura 14). Entretanto, na concetração de $1 \mu \mathrm{M}$ do inibidor de STAT1 houve uma diminuição da expressão de genes do perfil M1 ( $C c r 7$ e $C d 86)$ quando comparado a macrófagos M0 que eferocitaram AC-Sp na ausência do inibidor (Figura 14).

Por outro lado, a presença do inibidor de STAT3 durante a eferocitose de AC-Sp por macrófagos M0 resultou na inibição de genes do perfil M1 em ambas as concentrações, e na expressão de Fizzl na concentração de $1 \mu \mathrm{M}$. Observamos uma tendência à inibição de Argl e Cd206 em ambas às concentrações e de Fizzl na concentração de $0,1 \mu \mathrm{M}$ quando comparado aos macrófagos M0 cultivados na presença de AC-Sp na ausência de tratamento (Figura 14).

O tratamento com o inibidor de STAT1 em macrófagos M0 que fagocitaram AC-Sp resultou em uma tendência a menor liberação de IL-1 $\beta$ e redução da produção de IL-10, principalmente na menor concentração utilizada, quando comparado a macrófagos M0 que fagocitaram AC-Sp sem inibição dessa via de sinalização (Figura 14). Não foram observadas mudanças no perfil de liberação dos mediadores TNF- $\alpha$ e óxido nítrico durante o bloqueio de STAT1 quando comparado aos macrófagos M0 na presença de AC-Sp.

O tratamento com o inibidor de STAT3 em macrófagos M0 que fagocitam AC$S p$ resultou em um modesto aumento da liberação de TNF- $\alpha$ e tendência à diminuição da produção de IL-10 quando comparado a macrófagos que não sofreram o bloqueio desse fator de transcrição (Figura 14). Não observamos diferenças na produção de IL-1 $\beta$ e óxido nítrico nessa condição experimental. 
Figura 14. Perfil de expressão gênica e de mediadores secretados por macrófagos tratados com inibidores de STAT1 e STAT3 após a eferocitose de células apoptóticas infectadas com S. pneumoniae.

A)

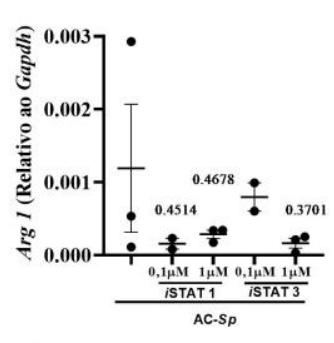

E)

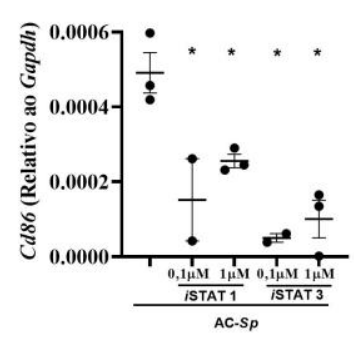

I)
B)

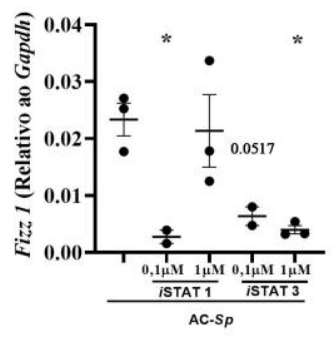

G)

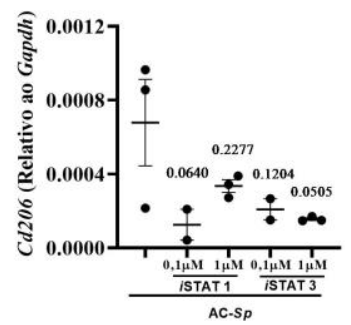

H)

D)
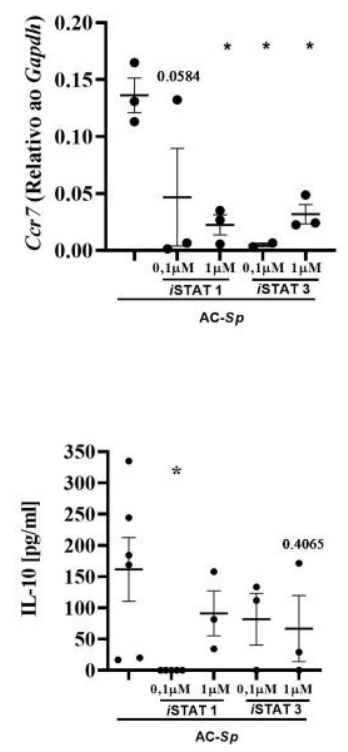

J)

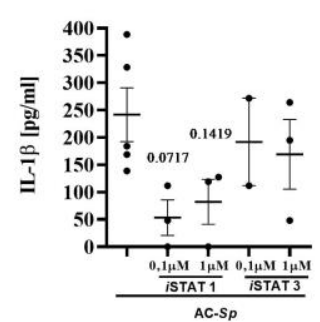

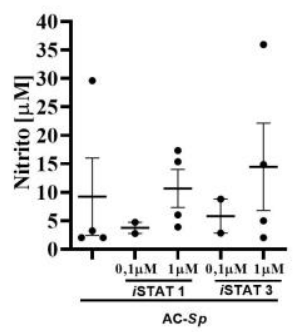
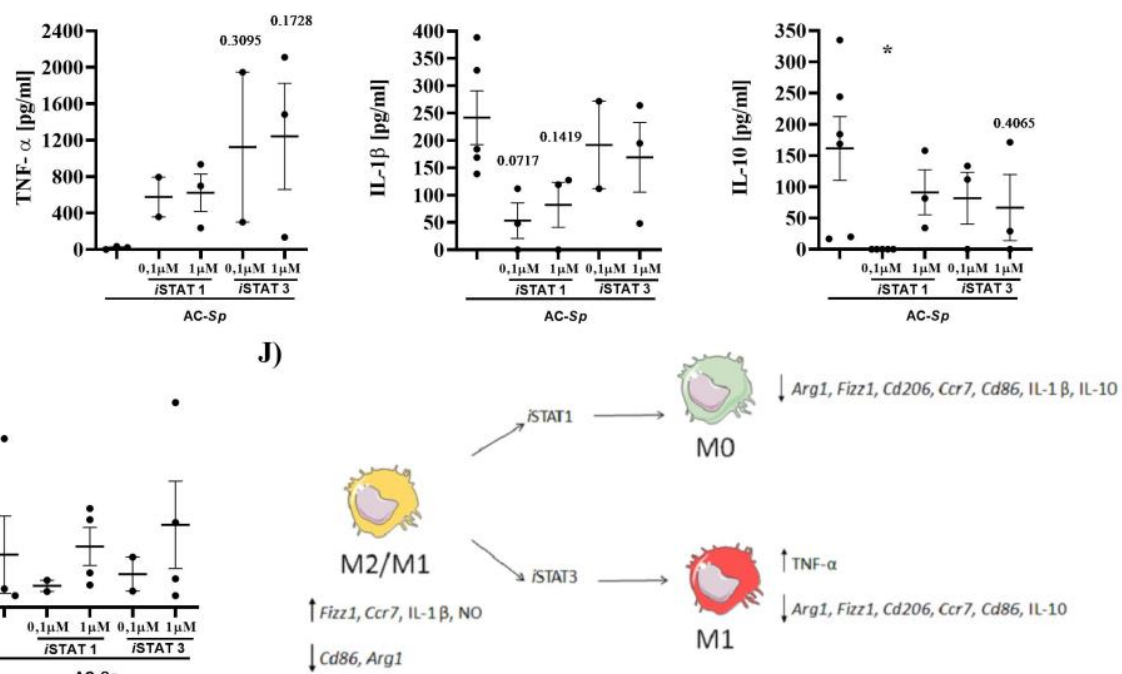

Os macrófagos M0 foram tratados com inibidor de STAT1 ou STAT3 (0,1 e 1 $1 \mu \mathrm{M})$ por 30 minutos. Após esse período, as células foram cultivadas na presença de AC-Sp na proporção 1 macrófago M0 a cada $3 \mathrm{AC}-\mathrm{Sp}$, por $2 \mathrm{~h}$. Em seguida, a cultura foi lavada e incubada com meio novo por subsequentes $24 \mathrm{~h}$. Após esse período, as células foram coletadas e a expressão dos genes foi analisada. A) $A r g 1$, B) $F i z z 1$, C) $C d 206$, D) $C c r 7$ e E) $C d 86$. Os sobrenadantes de cultura foram coletados e avaliados quanto à presença de diferentes mediadores. F) TNF- $\alpha, \mathbf{G})$ IL-1 $\beta$, H) IL-10, I) NO e J) Esquema representativo do perfil de polarização observado nos gráficos A-I; macrófagos M0: verde, macrófagos com perfil misto: amarelo e macrófagos com perfil misto dirigindo-se ao perfil M1: laranja. Resultados de F-H são expressos em pg/mL e o resultado de I é expresso em $\mu \mathrm{M}$. Média SEM da quantificação referente a 3-8 experimentos realizados individualmente. ${ }^{*} \mathrm{p}<0,05$ vs $\mathrm{M} 0+\mathrm{AC}-S p$. Valores de $\mathrm{p}$ entre 0,5 e 0,05 estão sinalizados no gráfico. 
A fagocitose de AC-Kp por macrófagos M0 na presença de $0,1 \mu \mathrm{M}$ do inibidor de STAT1 resultou em um aumento da expressão de $C d 206$ e $C c r 7$, quando comparado à fagocitose de AC-Kp por macrófagos M0 na ausência do inibidor de STAT1. Observamos, também, uma modesta inibição da expressão Arg1 e Cd206 na pr4esença de $1 \mu \mathrm{M}$ do inibidor de STAT1. Nenhuma modulação na expressão de Fizz1 e Cd86 foi observada durante a inibição do fator de transcrição STAT1 em qualquer das concentrações testadas $-0,1 \mu \mathrm{M}$ ou $1 \mu \mathrm{M}$ (Figura 15 ).

A eferocitose de AC- $K p$ por macrófagos M0 na presença de ambas as concentrações do inibidor do fator de transcrição STAT3 resultou em uma tendência à diminuição da expressão de Arg1, Fizzl e Cd206 e aumento da expressão de Cd86 quando essas células foram tratadas com $1 \mu \mathrm{M}$ do inibidor quando comparado a macrófagos M0 que fagocitaram AC-Kp na ausência do tratamento (Figura 15).

A liberação de TNF- $\alpha$ e IL-10 por macrófagos cocultivados com AC- Kp foi inibida na presença do inibidor de $\operatorname{STAT} 1(0,1 \mu \mathrm{M}$ e $1 \mu \mathrm{M})$ quando comparado à condição cocultivada com AC- $K p$ na ausência do tratamento farmacológico. De forma semelhante ao observado durante o tratamento com inibidor de STAT1, a presença do inibidor de STAT3 durante a fagocitose de AC-Kp por macrófagos M0 promoveu a inibição da liberação de IL-10 e uma modesta diminuição da produção de TNF- $\alpha$, quando comparado aos macrófagos M0 que fagocitaram AC-Kp, na ausência de tratamento. Não foram observadas diferenças na produção de óxido nítrico e IL-1 $\beta$ durante o bloqueio da via de sinalização de STAT1 e STAT3 independente da concentração do inibidor utilizada (Figura 15). 
Figura 15. Perfil de expressão gênica e de mediadores secretados por macrófagos tratados com inibidores de STAT após a eferocitose de células apoptóticas infectadas com $K$. pneumoniae.

A)

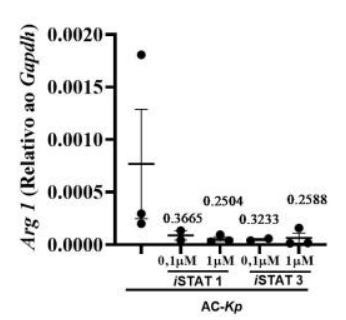

E)

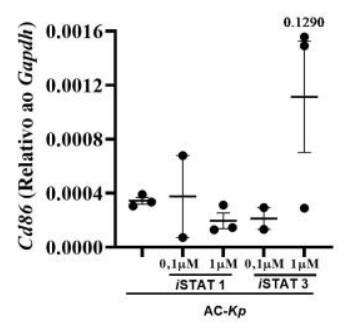

I)

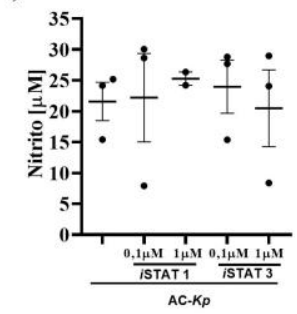

C)

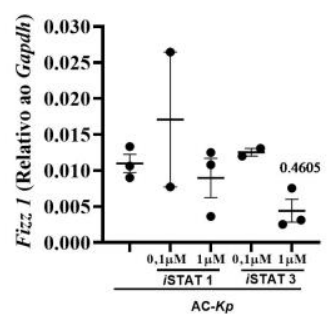

F)

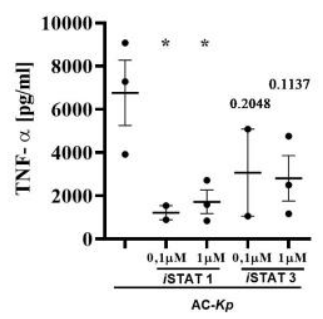

J)

G)
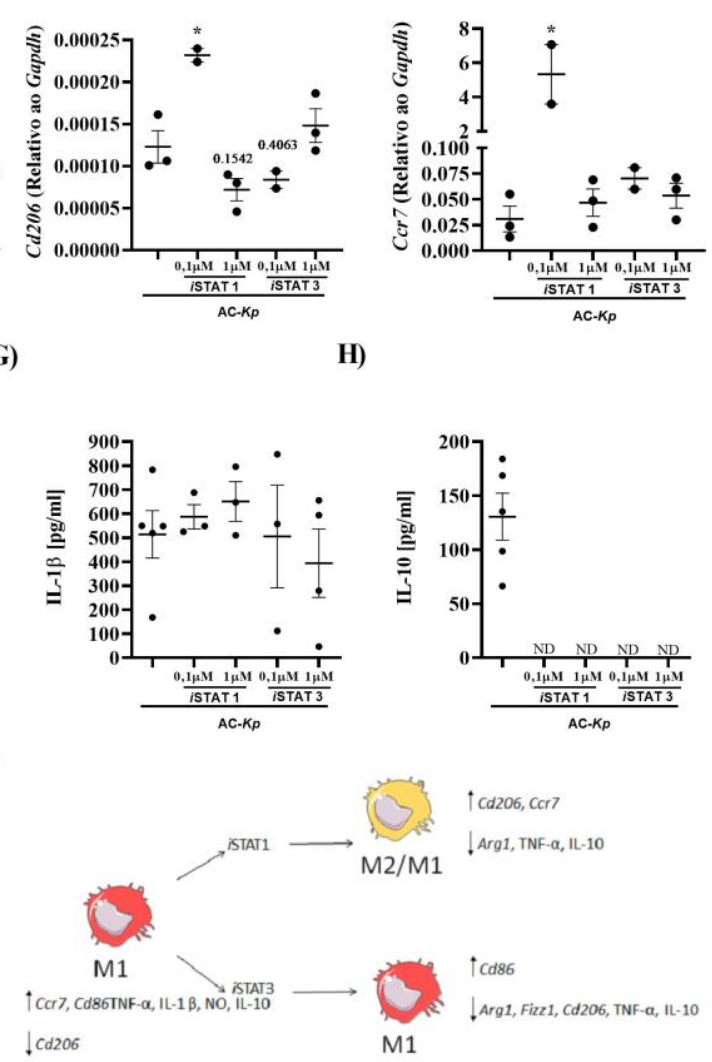

Os macrófagos M0 foram tratados com inibidor de STAT1 ou STAT3 $(0,1$ e $1 \mu \mathrm{M})$ por 30 minutos. Após esse período, as células foram cultivadas na presença de AC- $K p$ na proporção 1 macrófago M0 a cada $3 \mathrm{AC}-\mathrm{Sp}$, por $2 \mathrm{~h}$. Em seguida, a cultura foi lavada e incubada com meio novo por subsequentes $24 \mathrm{~h}$. Após esse período, as células foram coletadas e a expressão dos genes foi analisada. A) Arg1, B) Fizzl, C) $C d 206$, D) $C c r 7$ e E) $C d 86$. Os sobrenadantes de cultura foram coletados e avaliados quanto à presença de diferentes mediadores. F) TNF- $\alpha, \mathbf{G})$ IL-1 $\beta, \mathbf{H})$ IL-10, I) NO e J) Esquema representativo do perfil de polarização observado nos gráficos A-I; macrófagos M1: vermelho e macrófagos com perfil misto: amarelo. Resultados de F-H são expressos em $\mathrm{pg} / \mathrm{mL}$ e o resultado de I é expresso em $\mu \mathrm{M}$. Média \pm SEM da quantificação referente a $2-5$ experimentos realizados individualmente. ${ }^{*} \mathrm{p}<0,05$ vs M0+AC-Kp. Valores de p entre 0,5 e 0,05 estão sinalizados no gráfico. 
5.8. Participação da via não canônica do inflamassoma no perfil de ativação de macrófagos M0 após a eferocitose de células apoptóticas estéreis ou infectadas com S. pneumoniae ou K. pneumoniae.

Durante a eferocitose de células apoptóticas infectadas, o patógeno ou fragmentos deste, podem acessar o citoplasma celular e desencadear a ativação PRRs presentes nesse compartimento celular. O escape de patógenos, ou seus componentes, do microambiente fagossomal foi previamente descrito nas infecções por $K$. pneumoniae (101-106) e S. pneumoniae $(49,107)$. Flood e colaboradores demonstraram que no modelo de câncer associado à colite, caspase 11 é necessária para a ativação de STAT1 e produção de citocinas inflamatórias (108). Assim, avaliamos se a eferocitose de células apoptóticas infectadas com $S$. pneumoniae ou $K$. pneumoniae ou AC modularia a ativação de macrófagos M0 dependente da ativação não canônica do inflamassoma, via ativação direta de caspase 11 .

A eferocitose de AC por macrófagos deficientes de caspase 11 resultou em uma diminuição e tendência à diminuição da expressão de $C c r 7$ (gene relacionado ao perfil M1) e Arg1 (gene relacionado ao perfil M2), respectivamente, quando comparado a eferocitose de AC por macrófagos derivados de animais selvagens. Observamos um modesto aumento da expressão de $C d 206$, porém, houve alterações na expressão de Fizzl e $C d 86$ nessa condição experimental (Figura 16).

A eferocitose de $\mathrm{AC}$ por macrófagos deficientes de caspase 11 não alterou $\mathrm{o}$ perfil de citocinas liberadas quando comparado a eferocitose de AC por macrófagos derivados de animais selvagens. Não foi detectada a produção de IL-1 $\beta$ durante a eferocitose de AC como demonstrado anteriormente (dados não mostrados). Macrófagos deficientes de caspase 11, quando eferocitam AC apresentam uma tendência ao aumento da liberação de óxido nítrico e uma tendência à diminuição na produção de TNF- $\alpha$ quando comparado aos macrófagos oriundos de animais WT (Figura 16). 
Figura 16. Perfil de expressão gênica e de mediadores secretados por macrófagos deficientes de caspase 11 após a eferocitose de células apoptóticas estéreis.

A)

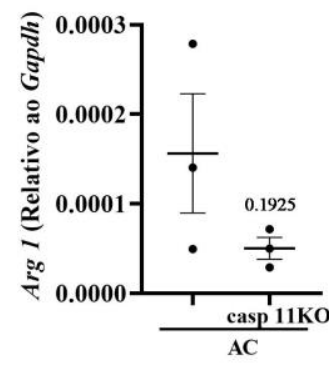

D)

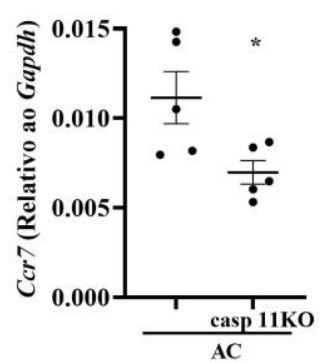

G)

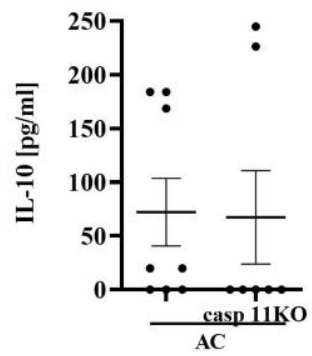

B)

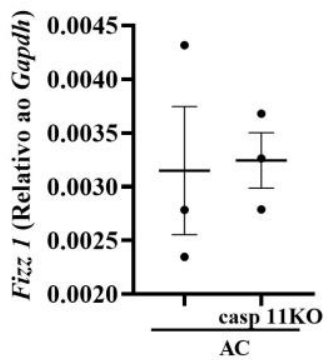

E)

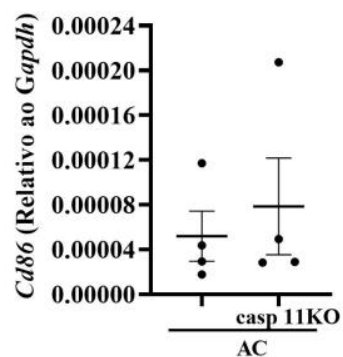

H)

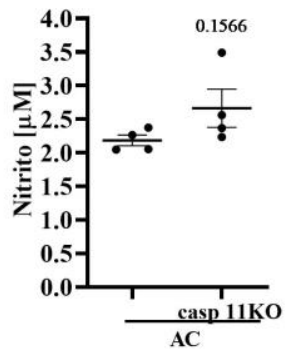

C)

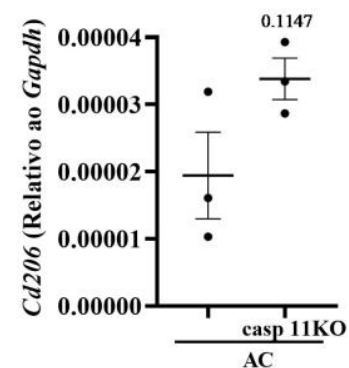

F)

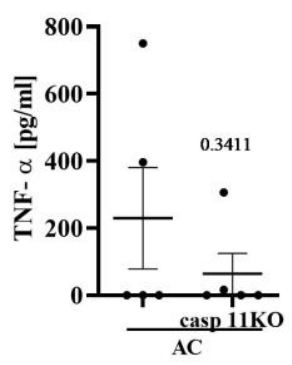

I)

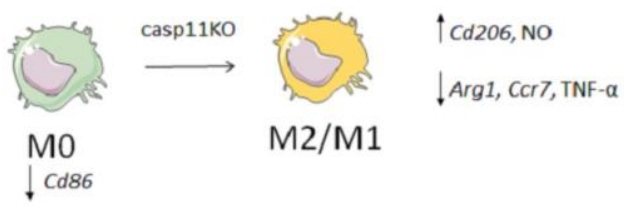

Os macrófagos M0 derivados de animais deficientes de caspase 11 foram cultivados na presença de AC na proporção 1 macrófago M0 a cada $3 \mathrm{AC}$, por $2 \mathrm{~h}$. Em seguida, a cultura foi lavada e incubada com meio novo por subsequentes $24 \mathrm{~h}$. Após esse período as células foram coletadas e a expressão dos genes foi analisada. A) $A r g 1$, B) $F i z z 1$, C) $C d 206$, D) $C c r 7$ e E) $C d 86$. Os sobrenadantes de cultura foram coletados e avaliados quanto à presença de diferentes mediadores. F) TNF- $\alpha$, G) IL-10, H) NO e I) Esquema representativo do perfil de polarização observado nos gráficos A-H; macrófagos M0: verde e macrófagos com perfil misto: amarelo. Resultados de F e G são expressos em pg/mL e o resultado de $\mathrm{H}$ é expresso em $\mu \mathrm{M}$. Média \pm SEM da quantificação referente a 3-8 experimentos realizados individualmente sem replicatas experimentais. ${ }^{*} \mathrm{p}<0,05$ vs M0-WT+AC. Valores de p entre 0,5 e 0,05 estão sinalizados no gráfico. 
A eferocitose de AC-Sp por macrófagos deficientes de caspase 11 resultou no aumento e tendência ao aumento da expressão de genes relacionados ao perfil M2, Cd206 e Argl e diminuição e tendência à diminuição da expressão de genes relacionados com o perfil M1, $C c r 7$ e $C d 86$ sugerindo uma mudança do perfil de ativação desses macrófagos na ausência de caspase 11 (Figura 17).

A análise do sobrenadante de cultura mostrou que macrófagos M0 derivados de animais deficientes para caspase 11 têm uma tendência à inibição da produção de IL-10 e uma tendência à produção de óxido nítrico após a eferocitose de AC-Sp, quando comparado a macrófagos oriundos de animais selvagens. Não observamos alteração na liberação de TNF- $\alpha$ e IL-1 $\beta$ (Figura 17). 
Figura 17. Perfil de expressão gênica de macrófagos deficientes de caspase 11 após a eferocitose de células apoptóticas infectadas com S. pneumoniae.

A)

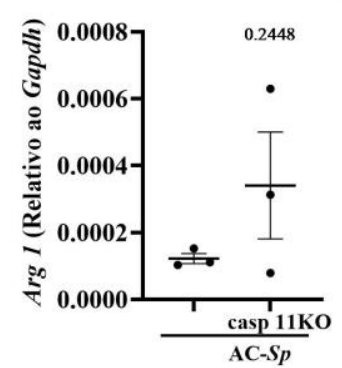

E)

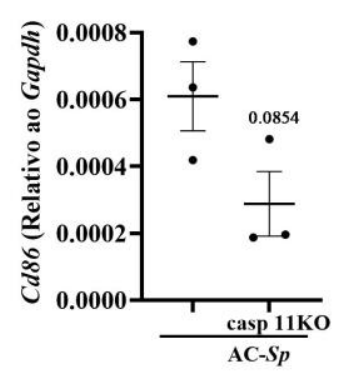

I)
B)

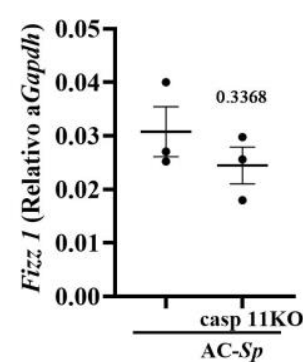

F)

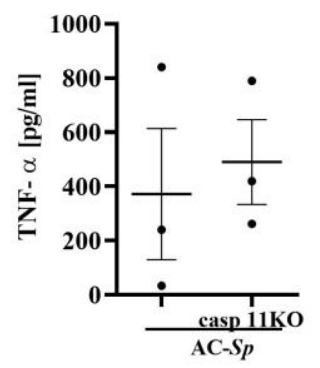

C)

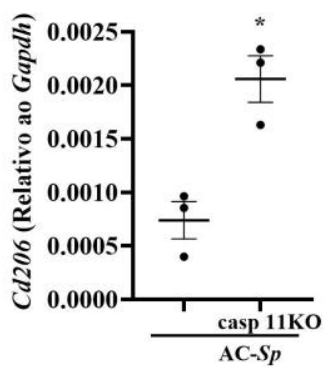

D)

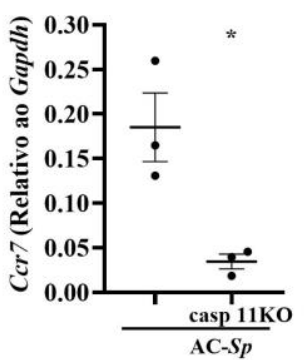

H)

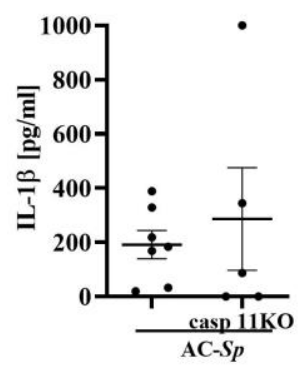

J)
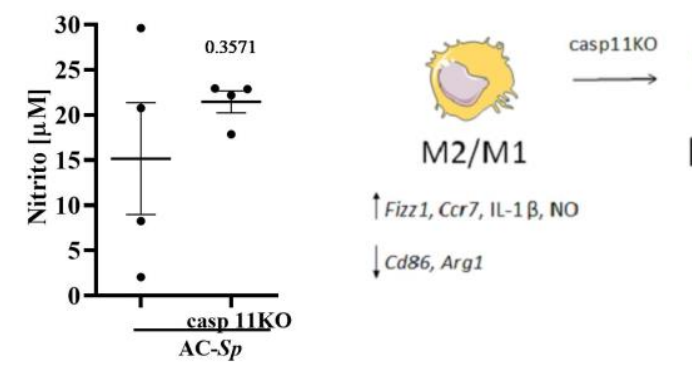

$\uparrow_{\text {Arg1, Cd206, NO }}$

! Fizz1, Ccr7, Cd86, IL-10

M2/M1

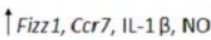

\Cd86, Arg1

Os macrófagos M0 derivados de animais deficientes de caspase 11 foram cultivados na presença de AC-Sp na proporção 1 macrófago M0 a cada 3 AC-Sp, por $2 \mathrm{~h}$. Em seguida, a cultura foi lavada e incubada com meio novo por subsequentes $24 \mathrm{~h}$. Após esse período as células foram coletadas e a expressão dos genes foi analisada. A) Arg1, B) Fizzl, C) $C d 206$, D) $C c r 7$ e E) $C d 86$. Os sobrenadantes de cultura foram coletados e avaliados quanto à presença de diferentes mediadores. F) TNF- $\alpha$, G) IL-1 $\beta$, H) IL-10, I) NO e J) Esquema representativo do perfil de polarização observado nos gráficos A-I; macrófagos com perfil misto: amarelo e macrófagos com perfil misto dirigindo-se ao perfil M2: azul claro. Resultados de F-H são expressos em $\mathrm{pg} / \mathrm{mL}$ e o resultado de I é expresso em $\mu \mathrm{M}$. Média \pm SEM da quantificação referente a 3-7 experimentos realizados individualmente. ${ }^{*} \mathrm{p}<0,05$ vs $\mathrm{M} 0+\mathrm{AC}-S p$. Valores de $\mathrm{p}$ entre 0,5 e 0,05 estão sinalizados no gráfico. 
A deficiência de caspase 11 em macrófagos M0 que eferocitaram AC- $K p$ resultou em uma tendência à diminuição na expressão de Ccr7, Fizzl e Cd206 quando comparado aos macrófagos M0 oriundos de animais selvagens incubados com AC-Kp. A ausência de caspase 11 não interferiu na expressão de Arg1 e Cd86 nas mesmas condições experimentais (Figura 18).

Macrófagos deficientes de caspase 11 que eferocitam AC- $K p$ apresentam inibição de TNF- $\alpha$ quando comparado aos macrófagos M0, oriundos de animais selvagens na presença de AC-Kp. No entanto, não houve alterações quanto à produção de IL-10, óxido nítrico, tão pouco de IL-1 $\beta$ por macrófagos, na ausência ou presença de caspase 11 durante a eferocitose de AC- $\mathrm{Kp}$ (Figura 18). 
Figura 18. Perfil de expressão gênica e de mediadores secretados por macrófagos deficientes de caspase 11 após a eferocitose de células apoptóticas infectadas com $K$. pneumoniae.

A)

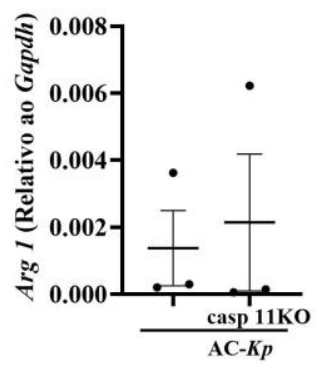

E)

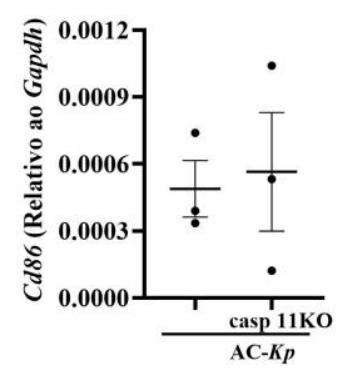

B)

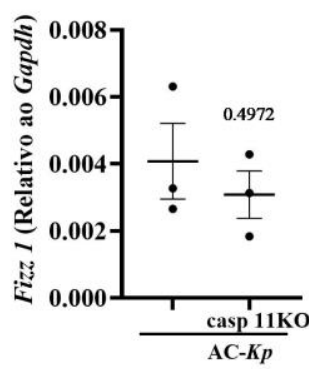

F)

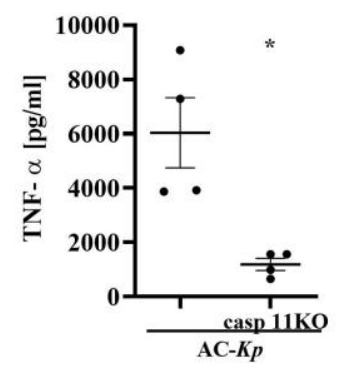

C)

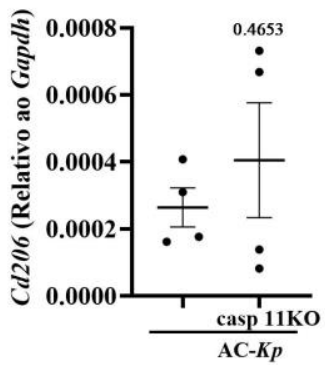

G)

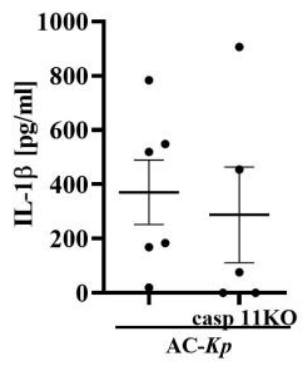

D)

H)
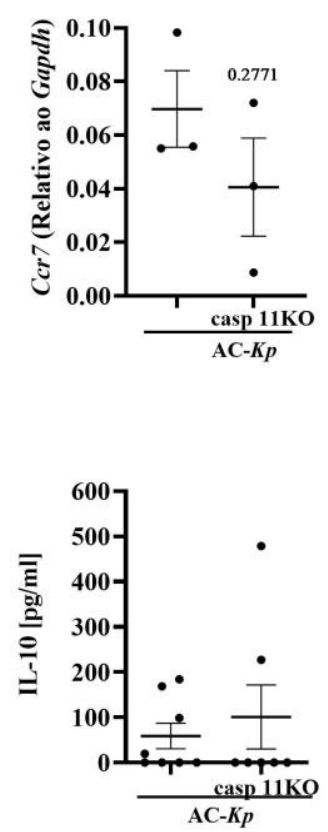

I)

J)
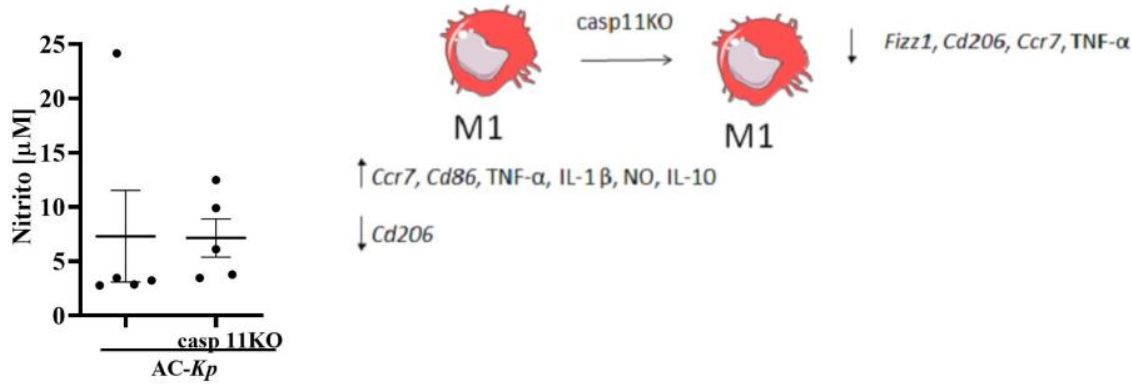

$\uparrow_{C C r 7}, C d 86$, TNF- $\alpha$, IL-1 $\beta$, NO, IL-10

$\downarrow$ Cd206

Os macrófagos M0 derivados de animais deficientes de caspase 11foram cultivados na presença de $\mathrm{AC}-K p$ na proporção 1 macrófago M0 a cada $3 \mathrm{AC}-K p$, por $2 \mathrm{~h}$. Em seguida, a cultura foi lavada e incubada com meio novo por subsequentes 24h. Após esse período as células foram coletadas e a expressão dos genes foi analisada. A) Arg1, B) Fizz1, C) Cd206, D) Ccr7 e E) Cd86. Os sobrenadantes de cultura foram coletados e avaliados quanto à presença de diferentes mediadores. F) TNF- $\alpha, \mathbf{G})$ IL-1 $\beta, \mathbf{H})$ IL-10, I) NO e J) Esquema representativo do perfil de polarização observado nos gráficos A-I; macrófagos M1: vermelho e macrófagos com perfil misto: amarelo. Resultados de F-H são expressos em pg/mL e o resultado de I é expresso em $\mu \mathrm{M}$. Média \pm SEM da quantificação referente a 3-8 experimentos realizados individualmente. $* \mathrm{p}<0,05$ vs M0+AC- $k p$. Valores de p entre 0,5 e 0,05 estão sinalizados no gráfico. 
5.9. Efeito da instilação de células apoptóticas estéreis ou infectadas com $S$. pneumoniae ou $K$. pneumoniae no microambiente pulmonar.

Durante a fase de resolução de uma infecção, os monócitos e neutrófilos que migraram para o tecido infectado para conter a proliferação bacteriana entram em processo de morte celular, gerando o acúmulo de células apoptóticas infectadas que são removidas principalmente por macrófagos. Dessa forma, avaliamos como células apoptóticas infectadas com $S$. pneumoniae ou $K$. pneumoniae influenciaraim no ambiente pulmonar. Para isso, AC-Sp ou AC- Kp foram instiladas e, após $24 \mathrm{~h}$, os pulmões foram coletados e determinou-se a expressão de genes relacionados ao perfil M1/M2 de ativação macrófagos e a liberação de citocinas no microambiente pulmonar.

A instilação dos animais com $\mathrm{AC}-\mathrm{Sp}$ não alterou a expressão dos genes avaliados quando comparado aos animais tratados apenas com PBS (Figura 19). Por outro lado, a instilação de $\mathrm{AC}-K p$ induziu aumento da expressão tanto de genes relacionados ao perfil M2, Arg1, como $C c r 7$, relacionado com o perfil M1 de ativação de macrófagos quando comparamos ao grupo que recebeu apenas AC. Observamos também uma tendência ao aumento da expressão de Fizzl, Cd86 e Cd206 nessa condição experimental (Figura 19). 
Figura 19. Perfil de expressão gênica de células pulmonares após a eferocitose dos diferentes tipos de células apoptóticas.

A)

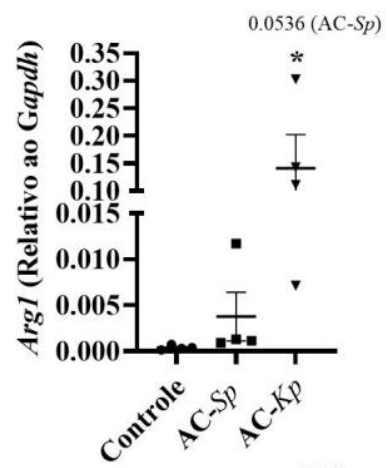

D)
B)

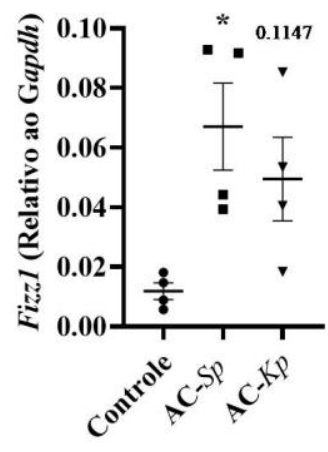

C)

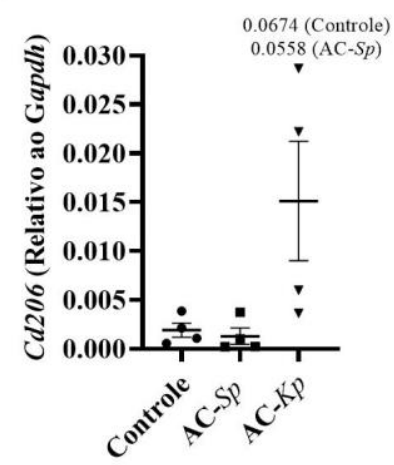

E)
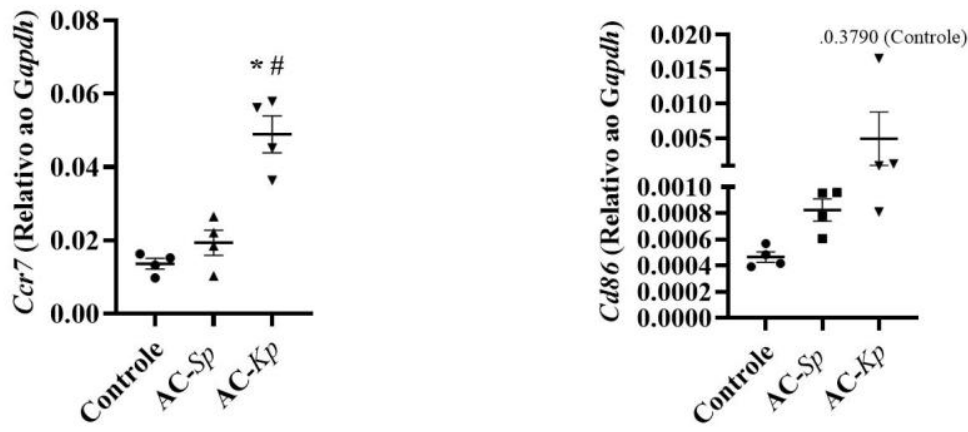

Animais C57B1/6 foram instilados com aproximadamente $10^{7}$ células apoptóticas (AC-Sp e AC$K p)$ ou PBS. Após 24h, os animais foram sacrificados, os pulmões coletados, digeridos com $1.6 \mathrm{mg} / \mathrm{mL}$ de colagenase $\mathrm{D}$ por $1 \mathrm{~h}$. As células foram lisadas e a expressão gênica foi avaliada por qPCR. A) $A r g 1$, B) Fizzl, C) $C d 206$, D) $C c r 7$ e E) $C d 86$. Resultado referente a 1 experimento com 4 animais por grupo. ${ }^{*} \mathrm{p}<0,05$ vs PBS e \#p<0,05 vs AC-Sp. Valores de $\mathrm{p}$ entre 0,5 e 0,05 estão sinalizados no gráfico. 
O desafio com AC-Sp resultou na produção de IL-10 e uma tendência à diminuição de IL-6 no homogenato de pulmão quando comparado ao grupo instilado com PBS (Figura 20).

O homogento de pulmão dos animais instilados com $\mathrm{AC}-K p$ apresentou maiores concentraçõesde TNF- $\alpha$, IL-1 $\beta$, TGF- $\beta$, IL-10, IL-4 e IL-12 e uma modesta variação na produção dos mediadores IL-6 e NO quando comparado à detecção desses mediadores no pulmão de animais que receberam apenas PBS (Figura 20). Observamos também um aumento na liberação de IL-12, TGF- $\beta$, IL-10, TNF- $\alpha$, IL-1 $\beta$, IL-6 e uma tendência ao aumento na produção de IL-4 no pulmão de animais instilados com AC-Kp quando comparado às citocinas produzidas no pulmão de animais instilados com AC-Sp. 
Figura 20. Citocinas produzidas no pulmão dos animais que receberam células apoptóticas estéreis, células apoptóticas infectadas com S. pneumoniae ou células apoptóticas infectadas com K. pneumoniae.
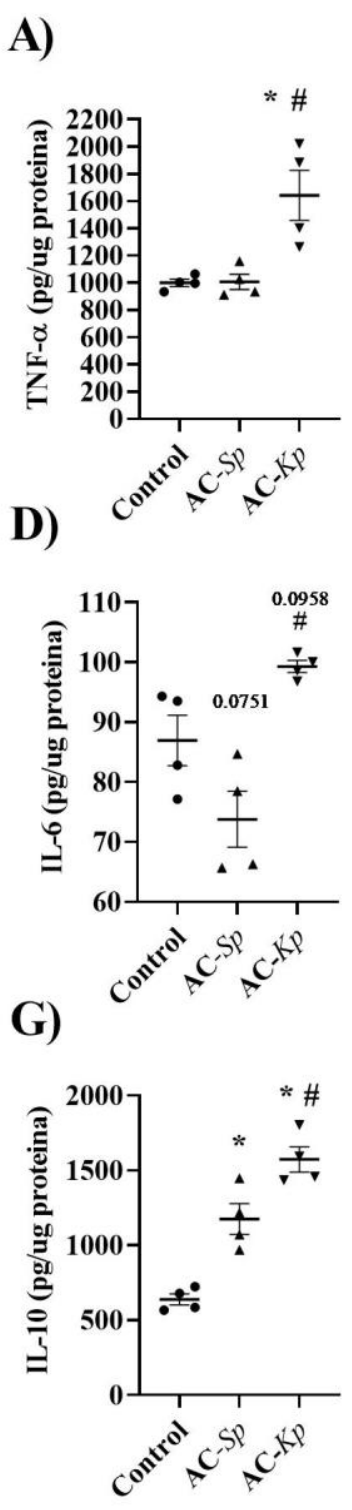

B)
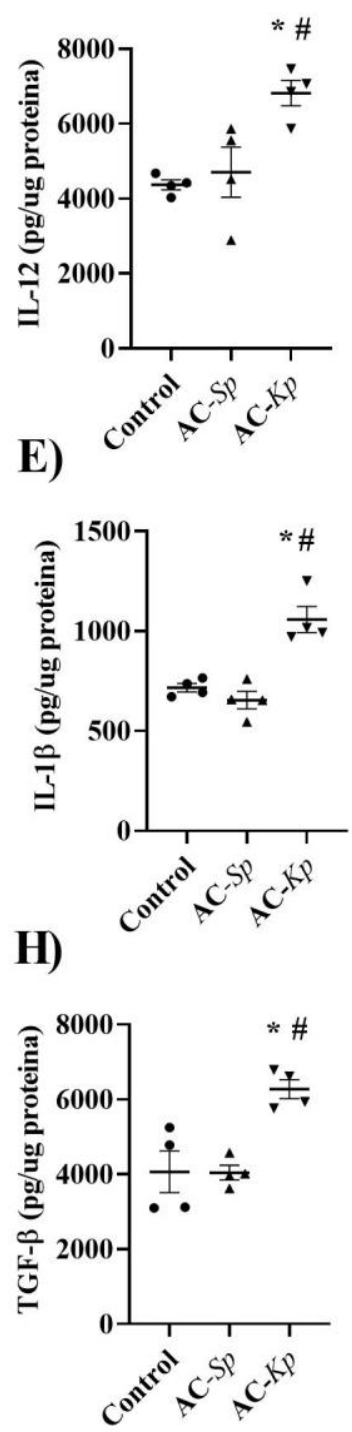

C)
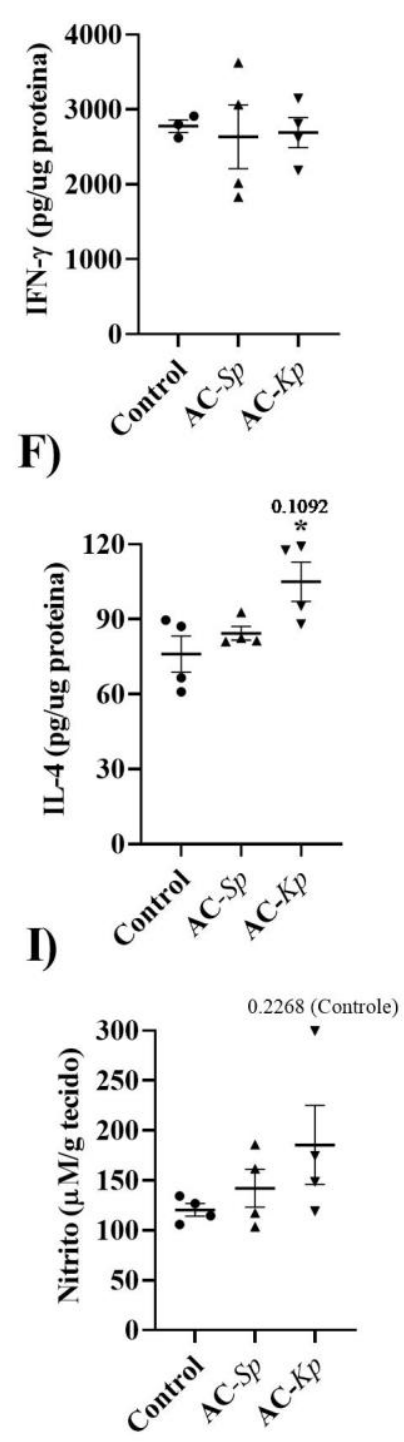

Animais C57B1/6 foram instilados com aproximadamente $10^{7}$ células apoptóticas (AC-Sp e AC$K p$ ) ou PBS. Após 24h, os animais foram sacrificados, os pulmões foram coletados, macerados em solução de PBS como inibidor de protease, e os mediadores foram avaliados. A) TNF- $\alpha$, B) IL-12, C) IFN- $\gamma$, D) IL-6, E) IL-1 $\beta$, F) IL-4, G) IL-10, H) TGF- $\beta$ e I) NO. Resultados de A-H são expressos em $\mathrm{pg} / \mu \mathrm{g}$ de proteína e o resultado de I é expresso em $\mu \mathrm{M} / \mathrm{g}$ de tecido. Resultado referente a 1 experimento com 4 animais por grupo. ${ }^{*} \mathrm{p}<0,05$ vs $\mathrm{PBS}$ e \#p $<0,05$ vs AC-Sp. Valores de p entre 0,5 e 0,05 estão sinalizados no gráfico. 


\section{DISCUSSÃO}

A morte celular por apoptose nos diferentes tecidos é um processo fisiológico envolvido no desenvolvimento, manutenção e remodelamento tecidual (3). A rápida remoção desses corpos apoptóticos por fagócitos, como os macrófagos, é imprescindível para a manutenção da homeostase tecidual, impedindo a progressão do estágio de morte por apoptose para um quadro de necrose celular que resulta em dano tecidual (3). A remoção dessas células promove a liberação de mediadores antiinflamatórios como IL-10 e TGF- $\beta$ resultando na ativação de macrófagos a um perfil M2 (34). Entretanto, durante um processo infeccioso, há um acúmulo de células apoptóticas que possuem em seu interior o patógeno. Prévios estudos demonstram que a fagocitose de células apoptóticas infectadas com bactéria $(33,109)$, vírus (110-113) e parasitas (114-117) acarreta na geração de um microambiente inflamatório, diferente do gerado pela eferocitose de células estéreis (33). Até momento, pouco se sabe se a natureza da bactéria contida no interior das células apoptótica poderia influenciar no perfil de polarização de macrófagos. Portanto, nesse trabalho buscamos entender os mecanismos pelos quais a eferocitose de células apoptóticas infectadas com uma bactéria Gram-positiva ou uma bactéria Gram-negativa poderiam desencadear a ativação diferenciada de macrófagos para o perfil M1 ou M2 de ativação celular.

Prévios relatos demonstram que macrófagos alveolares, BMDM, esplênicos e peritoneais são hábeis em fagocitar eficientemente células apoptóticas (106, 118-120), bem como adquirir tanto o perfil M1 como M2 (121).

Zhong e colaboradores demonstraram que a eferocitose de neutrófilos apoptóticos estéreis por macrófagos peritoneais induz a ativação dessas células para um perfil M2 com aumento da expressão de Arg1, Fizzl e Cd206 (122). Nossos resultados demonstram que a eferocitose de AC não alterou a expressão dos genes relacionados ao perfil M2, Arg1, Fizzl e Cd206, bem como a produção de IL-10 que é descrita na literatura $(70,72,122,123)$. Essa incongruência de resultados pode ser justificada tanto pelo tipo de célula escolhida como fonte de células apoptóticas como, também, pelo tipo de macrófago utilizando nos estudos. Diversos autores utilizam timócitos murinos ou humanos (linhagem celular Jurkat T cells) como fonte de células apoptóticas (16, 34, 35, 122, 124). Timócitos são células incapazes de fagocitar microrganismos, dessa 
forma, não puderíamos utilizar essa fonte celular para a geração de nossas células apoptóticas infectadas. Resultados prévios do nosso grupo demostram que a fonte de célula apoptótica pode influenciar no padrão de citocinas secretadas por CDs e, consequentemente, ativar distintos tipos de linfócitos T. CDs que eferocitam neutrófilos primários apoptóticos estéreis isolados do peritônio de ratos induzem a diferenciação de linfócitos Th1 ao invés de linfócitos T reguladores, sugerindo que células apoptóticas derivadas de neutrófilos liberam moléculas que induzem uma resposta mais inflamatória (Niño Castanho, tese de doutorado).

Além disso, o tipo de receptor envolvido no englobamento das células apoptóticas influencia no padrão de mediadores liberados pelos fagócitos. Macrófagos derivados de monócitos humanos apresentam uma produção diferente de IL-10 e TFG- $\beta$ quando incubados com neutrófilos humanos apoptóticos opsonizados ou neutrófilos humanos apoptóticos não opsonizado $(34,125)$. Experimentos futuros serão necessários para compararmos o efeito da eferocitose, em BMDM, utilizando outras diferentes linhagens celulares com capacidade fagocítica, como J774A.1 ou AMJ2, ou macrófagos peritoneais como fonte de células apoptóticas.

Embora diferentes receptores eferocíticos atuem durante a eferocitose de células estéreis promovendo o reconhecimento e internalização das dessas células, a ativação gerada pelas diferentes vias sinalização, receptores TIM e CD36, culminam na produção de mediadores anti-inflamatórios $(126,127)$. Entretanto, durante a eferocitose de uma célula apoptótica infectada ocorre o reconhecimento tanto de PS, via receptores eferocíticos, como de PAMPs, via PRR. A interação desses PRR ocorreria durante a degradação do corpo apoptótico infectado no interior do fagolisossomo desencadeando a liberação de mediadores tanto inflamatórios com anti-inflamatórios. Estudos prévios demonstraram que durante o processo de eferocitose de células apoptóticas infectadas por E. coli ocorre a translocação de TLR4 para o interior do fagossomo onde esse receptor é capaz de promover o reconhecimento do patógenos e/ou PAMPs $(33,92,93)$. Além disso, nós e outro grupo de pesquisa demonstramos que a eferocitose de células apoptóticas infectadas com Citrobacter rodentium por CDs induz a produção de IL-6 e TGF- $\beta$, desencadeado pelo reconhecimento de PAMP e PS, respectivamente $(33,109)$. No que diz respeito à ativação de macrófagos, nós observamos que a eferocitose de 
células apoptóticas infectadas com $S$. pneumoniae desencadeia um perfil misto de polarização dos macrófagos com aumento na expressão de Fizzl, relacionado ao perfil M2, bem como de $C c r 7$ e mediadores inflamatórios como IL-1 $\beta$ e óxido nítrico, marcadores relacionados ao perfil M1 de ativação.

Não há um consenso na literatura sobre o perfil de ativação de macrófagos após a infecção por S. pneumoniae, por si só. Se por um lado, alguns trabalhos relatam que as respostas ao S. pneumoniae são caracterizadas por uma intensa reação inflamatória e a polarização de macrófagos ao perfil M1 dependente de TLR2 (128, 129), Knippenberg e colaboradores demonstraram que a infecção por S. pneumoniae desencadeia a expressão de Argl em macrófagos alveolares agravando o quadro de infecção (130). Somado a isso, Koffel e colaboradores demonstraram que macrófagos estimulados com lipossomos contendo pneumolisina derivada de $S$. pneumoniae adquirem um fenótipo $\mathrm{CD}_{14}{ }^{+} \mathrm{MHCII}^{\text {low }} \mathrm{CD}^{\text {low }}{ }^{\text {TLR2 }}{ }^{\text {hi }} \mathrm{NOD}^{+}$com produção de IL-1 $\beta$, TNF- $\alpha$, IL-6. A regulação negativa das moléculas de MHC-II e CD86 está relacionada ao perfil M2 de macrófagos, porém nesse estudo também não foi detectado o aumento da expressão de moléculas amplamente relacionas ao perfil M2 de macrófagos, como CD206 e CD163 (131). Estudos envolvendo outra bactéria do mesmo gênero, Streptococcus pyogenes, demonstram que a fagocitose desse patógeno induz a produção de citocinas inflamatórias relacionadas ao perfil M1 como também promove a produção de IL-10 e arginase, respostas típicas do perfil M2 (132). Assim, os resultados obtidos nesse trabalho em relação à eferocitose de células apoptóticas infectadas com S. pneumoniae sugerem que reconhecimento tanto de sinais de eat-me, via receptores eferocíticos, como de sinais mediados pela interação PAMP-PRR, pela presença do patógeno, resultam na ativação de um padrão misto de polarização M1/M2 nos macrófagos avaliados.

Macrófagos M0 na presença de células apoptóticas infectadas com $K$. pneumoniae apresentaram fenótipo M1 predominante, com tendência ao aumento dos genes relacionados ao perfil M1 como $C c r 7$ e tendência à diminuição de genes do perfil M2, como Cd206. Além disso, foi detectado um aumento na produção de mediadores inflamatórios, como óxido nítrico e IL-1 $\beta$. Nosso grupo de pesquisa demonstrou recentemente que a fagocitose de $K$. pneumoniae por BMDM resultou na ativação do 
perfil M1, ou seja com um fenótipo caracterizado por baixa expressão de $C d 206, \operatorname{Arg} 1$ e Fizz1 (relacionados ao perfil M2) e alta expressão de Nos2 e Il6 (relacionados ao perfil M1) (106). Por outro lado, alguns estudos sugerem que a infecção por K. pneumoniae induz a ativação de macrófagos para um fenótipo M2, uma vez que macrófagos passam a expressar altos níveis de IL-10 resultando na ativação de STAT6, relacionado ao perfil M2 de ativação de macrófagos $(133,134)$. A presença de $K$. pneumoniae no interior de células apoptóticas não resultou no aumento de liberação de IL-10 por macrófago em nossas condições experimentais. Novos experimentos serão necessários para comprovar o efeito da eferocitose na ativação desses macrófagos, como o tratamento com citocalasina $\mathrm{D}$, que inibe a polimerização da actina, e o tratamento das células apoptóticas com anexina $\mathrm{V}$ purificada. Esses são protocolos bem estabelecidos na literatura para bloqueio de fagocitose de AC e serão fundamentais para comprovar os efeitos observados na ativação de macrófagos.

Sabe-se que TLR2 e TLR4 são capazes de reconhecer tanto $S$. pneumoniae como K. pneumoniae e promover a ativação celular quando ativados por LTA e LPS, respectivamente $(39-44,90,135)$. Prévios estudos demonstram que TLR4 também é importante durante a ativação celular após a ingestão de células apoptóticas infectadas. O microambiente gerado pela fagocitose de neutrófilos apoptóticos infectados com $E$. coli por CDs é dependente de TLR4 (33). No modelo de infecção por Trypanosoma cruzi, CDs que fagocitam células apoptóticas na presença de ligantes de TLR4 derivados do parasita (glicoinositolfosfolipídeos - GIPL) produzem um microambiente inflamatório capaz de promover a migração de neutrófilos importante para o combate à infecção (117).

Na ausência de TLR2, os macrófagos que eferocitaram AC-Sp parecem adquirir um fenótipo mais M2, com uma tendência ao aumento da expressão de Argl. Por outro lado, na ausência de TLR4, os macrófagos que eferocitaram AC-Sp apresentam aumento na produção de IL-1 $\beta$. Embora alguns estudos demonstrem que TLR2 e TLR4 atuam de forma sinérgica no reconhecimento e ativação por $S$. pneumoniae $(44,90)$, os principais componentes envolvidos no reconhecimento desse patógeno são LTA e lipoproteínas via TLR2 $(39,40,136)$. Portanto, nossos dados sugerem que a eferocitose de AC-Sp na ausência de TLR2 resulta em macrófagos com fenótipo mais M2. 
A eferocitose de AC-Kp por macrófagos deficientes de TLR2 induziu uma resposta ambígua. Houve tanto uma tendência a aumento da expressão de $C d 206$, como uma modesta inibição da produção de IL-10, ambos marcadores do perfil M2. A ausência de TLR4 em macrófagos resultou em uma alteração no estado de ativação dessas células. Foi observada uma tendência à diminuição na expressão de $C c r 7$ bem como na produção de IL-1 $\beta$, sem alterar a liberação de mediadores inflamatórios como TNF- $\alpha$ e NO. Sabe-se que TLR4 é um receptor importante pra indução do perfil M1 em macrófagos (137). Além disso, estudos demonstram que esse receptor é imprescindível para a sobrevivência de animais infectados com $K$. pneumoniae, uma vez que animais deficientes para esse receptor apresentam redução na sobrevivência, danos teciduais mais severos e aumento na proliferação bacteriana (42, 138). Assim, nossos resultados corroboram com a literatura visto que na ausência de TLR4 teríamos uma diminuição no perfil M1 de ativação.

A eferocitose de AC por macrófagos deficientes de TLR2 ou TLR4 não alterou o estado de polarização dos macrófagos. Não observamos alterações na expressão dos genes avaliados e na produção dos mediadores inflamatórios e anti-inflamatórios. Esse é um dado esperado, uma vez que se tratava de uma célula apoptótica estéril que não possui em seu interior o patógeno ou fragmentos destes, e, consequentemente, não induziria um reconhecimento via TLRs.

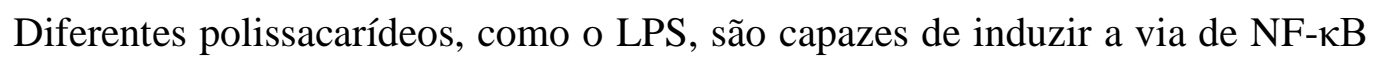
dependente de TLR4 desencadeando na ativação de macrófagos para um perfil M1 $(139,140)$. Estudos demonstram que a inibição da subunidade p65 do NF-кB prejudica o desencadeamento do perfil M1 dessas células modulando negativamente a expressão de IL-12, MHC-II e Nos2 e, consequentemente, favorecendo o perfil M2 (141). Por outro lado, a subunidade p50 é uma molécula chave para a ativação de macrófagos M2 (142). Somado a isso, Szondy e colaboradores demonstraram que a eferocitose de AC induz a inibição de NF- $\kappa \mathrm{B}$ via PPAR $\gamma$ (143). Diferentes trabalhos demonstraram que a expressão de CCR7 e CD86 é regulada positivamente pela ativação de NF-кB (144147). Em contrapartida, a inibição dessa via de sinalização também é descrita por inibir a expressão de $C d 206$, TGF- $\beta$, IL-10, Arg1, Fizzl e a translocação da unidade de p65

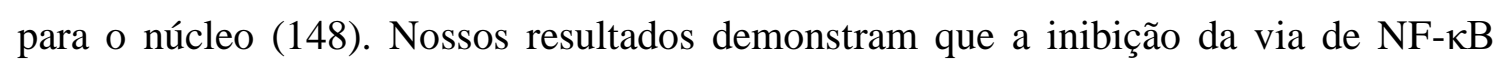


durante a eferocitose de $\mathrm{AC}$ resultou em um aumento na expressão tanto de genes relacionados ao perfil M1, Cd86, quanto de genes relacionados ao perfil M2, Arg1. O mesmo padrão de resposta foi observado na liberação dos mediadores por esses macrófagos, ou seja, houve uma diminuição na produção de IL-10 assim como uma tendência ao aumento da produção de óxido nítrico por essas células. Embora a inibição de NF- $\kappa$ B esteja envolvida nas vias de sinalização dos diferentes receptores eferocíticos durante o englobamento das células apoptóticas (149-151), outras vias podem também participar desse processo de ativação. A perda de PPAR $\delta$ induz uma menor produção de IL-10 e aumento de TNF- $\alpha$ e IL-12 em macrófagos cultivados com AC (152). Rothlin e colaboradores demonstraram que a inibição de STAT1 via TAM/IFN- $\alpha$ também é descrita nesse contexto (153). O bloqueio de receptores nucleares como RXR $\alpha$ e Nr4a1

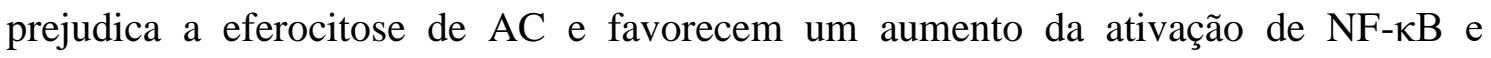
produção de mediadores inflamatórios $(154,155)$. Estudos demonstram que na ausência da ativação de NF- $\mathrm{B}$, pode ocorrer à ativação prolongada de JNK em reposta ao TNF- $\alpha$ $(156,157)$. Assim, a inibição de NF- $\kappa \mathrm{B}$ em nosso modelo poderia favorecer outras vias de sinalizações como a de JNK. Estímulos provenientes da ligação de PAMPs com TLR3/4/9 e citocinas como TNF- $\alpha$, IL-1 $\beta$ desencadeiam a ativação da via de sinalização de JNK (158) que por sua vez ativa o fator de transcrição AP.1. No modelo de artrite, a via de JNK/AP.1, em macrófagos, promove a inibição de Argl (159) favorecendo o perfil M1 de polarização de macrófagos. Esses estudos sugerem que durante a eferocitose de AC-Sp, mediante a inibição de $\mathrm{NF}-\kappa \mathrm{B}$, outras vias de sinalização são ativadas favorecendo o aumento na expressão de Cd206 e Cd86. Da mesma forma, durante a eferocitose de $\mathrm{AC}-K p$, o tratamento de macrófagos com inibidor de $\mathrm{NF}-\kappa \mathrm{B}$ resultou na diminuição da expressão de $C d 206$, e uma tendência à diminuição de Fizzl e Ccr7 e liberação de IL-1 $\beta$, sugerindo favorecimento para o perfil M2 $(139,140)$. Novos experimentos serão necessários para identificar outras possíveis vias de sinalização intracelular ativadas durante a eferocitose dessas células apoptóticas infectadas,

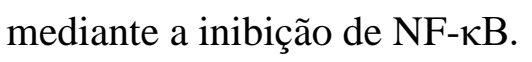

Lawrence e colaboradores demonstraram que o reconhecimento de $S$. pneumoniae induz a ativação tanto de STAT1 como de STAT3 no ambiente pulmonar (98). Por outro lado, o bloqueio de STAT1, durante a infecção por K. pneumoniae, 
favorece a resolução da infecção e promove aumento de IL-10, assim como a eferocitose de neutrófilos apoptóticos e ativação de STAT3 (100).

A eferocitose de AC por macrófagos, na presença do inibidor de STAT1, resultou em um perfil M1 (aumento da expressão de Arg1 e TNF- $\alpha$ e diminuição de IL10). Nesse trabalho não avaliamos a ativação compensatória de outras vias de sinalização, entretanto nossos dados sugerem que a ativação de outras STATs poderia ser uma das explicações que justificariam o aumento de Argl marcador da população de macrófagos M2.

A fagocitose de AC-Sp na presença do inibidor de STAT1 desencadeou uma diminuição na expressão de $F i z z 1$ e uma tendência à diminuição de $C d 206, C c r 7$ e $C d 86$ bem como diminuição na produção de IL-10 e IL-1 $\beta$. Por outro lado, a fagocitose de AC-Kp na presença do inibidor de STAT1 desencadeou um aumento na expressão dos genes relacionados a ambos os perfis e uma diminuição das citocinas também de ambos os perfis de ativação. Esse conjunto de resultados sugere que, na ausência de STAT1, macrófagos anteriormente que se polarizavam para um perfil misto de polarização, passam a adquirir um estado não polarizado, com a diminuição tanto de marcadores do perfil M1 quanto marcadores do perfil M2 de ativação celular. Pensando em um quadro infeccioso, a diminuição de um perfil inflamatório poderia favorecer o controle e resolução da inflamação, uma vez que é descrito que excesso de inflamação está relacionado ao aumento da liberação de DAMPs que favorecem o dano tecidual (160).

STAT3 é um dos fatores de transcrição envolvidos na polarização de macrófagos M2, portanto, corroborando a literatura, a inibição da via de sinalização de STAT3 durante a eferocitose de AC promoveu uma diminuição na liberação de IL-10, sugerindo uma manutenção do perfil M0 nesses macrófagos. De maneira semelhante ao que ocorreu durante a inibição de STAT1, a inibição de STAT3 durante a eferocitose de AC-Sp promoveu uma modulação negativa de genes do perfil M2, como Fizzl e Cd206, bem como de genes relacionados ao perfil M1 como $C c r 7$ e $C d 86$. Esses dados sugerem que a inibição de STAT3 pode estar favorecendo a ativação de outras vias relacionadas a um perfil inflamatório. A infecção por $S$. pneumoniae induz um aumento da concentração de IL-6 no pulmão dos animais infectados (161). Essa citocina está relacionada tanto a ativação de STAT1 como STAT3 $(162,163)$. A confirmação da 
ativação dessas STATs bem como a produção de IL-6 no sobrenadante de cultura serão avaliados visto a importância dessa molécula na ativação de STATs.

Além do reconhecimento via receptores do tipo TLR presentes no interior do fagolisossomo, prévios estudos demonstram o escape do patógeno ou toxinas para o citoplasma celular favorecendo a interação com receptores citosólicos. Essa capacidade de escape fagossomal já é descrita pra diferentes patógenos como Mycobacterium tuberculosis (101), Staphylococcus aureus (102), Shigella flexneri (103), Listeria monocytogenes (104), Francisella tularensis (105), K. pneumoniae (106), entre outros. A desestabilização lisossomal causada pelo $M$. tuberculosis favorece a liberação de catepsinas que ativam o inflamassoma de NLRP3 (164). Corroborando a esses dados, alguns estudos demonstraram que pneumolisina secretada pelo $S$. pneumoniae induz desestabilização lisossomal favorecendo o escape do patógeno para o citoplasma celular onde são reconhecidos por NLRP3 $(49,50)$. Dessa forma, tanto o patógeno como fragmentos destes e toxinas presentes no interior de células apoptóticas infectadas poderiam interagir com receptores citosólicos promovendo a ativação do inflamassoma e polarização de nossos macrófagos. A interação PAMPs/PRR induz o aumento da expressão de inflamassomas como NLRP3 e caspase 11 (165-168). NLRP3 pode ser ativado por inúmeros sinais como PAMPs, DAMPs, cristais, ATP, efluxo de $\mathrm{K}^{+}$e $\mathrm{Cl}^{-}$, fluxo de $\mathrm{Ca}^{2+}$, ruptura lisossomal, mtROS, cardiolipina, DNA oxidado, entre outros (169). Kayagaki e colaboradores demonstraram que a ativação da via não canônica do inflamassoma se dá pela ligação direta da molécula de LPS, e, portanto, independente de TLR4, com caspase 11 no citoplasma celular (170).

A eferocitose de AC-Sp por macrófagos deficientes de caspase 11 induziu um aumento na expressão de $C d 206$ bem como uma tendência ao aumento da expressão de Arg1. Concomitante a isso, observamos uma diminuição ou tendência à diminuição da expressão de $C c r 7$ e $C d 86$, respectivamente, sugerindo o favorecimento do perfil M2 de ativação em nossos macrófagos. Zanoni e colaboradores demonstraram que além da molécula de LPS, lipídeos oxidados como os oxPAPC também são responsáveis pela ativação da via não canônica do inflamassoma e produção de IL-1 $\beta$ sem induzir morte celular por piroptose em CDs $(56,57)$. Essas moléculas também são encontradas na membrana de corpos apoptóticos (171) e colaboram com o processo de eferocitose uma 
vez que o reconhecimento de oxPAPc via CD14 e CD36 promove a eliminação de AC $(17,172)$. A ativação da via não canônica do inflamassoma via lipídeos oxidados durante a polarização de macrófagos que fagocitam AC-Sp parecem ser importante para o fenótipo final dessas células uma vez que observamos o favorecimento do perfil M2 na ausência de caspase 11 .

A eferocitose de AC-Kp por macrófagos deficientes de caspase 11 resultou em uma diminuição na liberação de TNF- $\alpha$ e a tendência à diminuição da expressão de Ccr7, ambas as moléculas relacionadas ao perfil M1. Esses dados corroboram com a literatura, visto que animais deficientes de caspase 11 tem uma redução na ativação de STAT1 no modelo de colite carcinogênica e, portanto, uma diminuição no perfil M1 de ativação celular (108). Esses dados sugerem que, na ausência de caspase 11, esses macrófagos adquirem um fenótipo menos M1 tanto pela ausência de interação da molécula de LPS derivada do patógeno como pelas moléculas de oxPAPC. No entanto, experimentos adicionais são necessários avaliar a ativação de outros tipos de inflamassoma como, por exemplo, o inflamassoma de NLRP3 uma vez que estudos demonstram que tanto $S$. pneumoniae quanto $K$. pneumoniae desencadeiam a ativação dessa via $(52,106,173-175)$.

$\mathrm{Na}$ tentativa de aplicar os resultados obtidos in vitro, desenvolvemos um modelo in vivo onde poderíamos avaliar o microambiente pulmonar mediante a fagocitose das diferentes células apoptóticas. A instilação de AC-Sp induziu um aumento da expressão do gene Fizzl semelhante aos resultados in vitro obtidos pela fagocitose AC-Sp por BMDM. Observamos também a diminuição na liberação de IL-6 quando comparado aos animais tratados apenas com PBS que não havia sido observada nos experimentos in vitro. Esses resultados reforçam a importância de avaliarmos a produção de IL-6 em nossas condições experimentais.

Por outro lado, a instilação de AC- $K p$ induziu aumento ou tendência ao aumento da expressão tanto de genes relacionados ao perfil M2, Arg1, Fizzl e Cd206, como Ccr7, relacionado com o perfil M1 de ativação de macrófagos. A instilação de AC-Kp no aumento ou tendência ao aumento na a produção de todos os mediadores analisados com exceção de IFN- $\gamma$. Enquanto a instilação de células infectadas com $S$. pneumoniae parece resultar em um perfil de ativação menos inflamatório no ambiente pulmonar, a 
administração de células apoptóticas infectadas com $K$. pneumoniae resulta na geração de altos níveis de mediadores inflamatórios. Experimentos futuros serão imprescindíveis para determinar se a instilação das diferentes células apoptóticas seria capaz de modular o microambiente pulmonar favorecendo o cleareace bacteriano ou a diminuição do dano tecidual causado pelo acúmulo dessas células durante a infecção são importantes.

Vale ressaltar que durante os experimentos in vitro nós utilizamos uma cultura com quase totalidade de macrófagos M0 (95\%, dados não mostrados) para a fagocitose das diferentes células apoptóticas. Porém, nos experimentos in vivo, a análise da expressão gênica foi realizada a partir de todo o tecido pulmonar, envolvendo, portanto, tanto celulas teciduais como uma grande quantidade de neutrófilos provenientes do extravassamento induzido pela instilação. Experimentos analisando a expressão gênica apenas em macrófagos também são fundamentais para caracterizar o perfil dos macrófagos in vivo após o contato com as diferentes células apoptóticas.

O conjunto desses resultados contribui no entendimento de como a eferocitose no contexto da infecção poderia influência na polarização de macrófagos e nas respostas contra os diferentes microrganismos. A caracterização das vias de sinalização envolvidas na ativação desses fagócitos durante a eferocitose dessas células apoptóticas poderia ser utilizada como uma opção de tratamento auxiliando na reprogramação desses macrófagos para os perfils M1/M2. Ou seja, após a redução da carga bacteriana no local da infecção, a manutenção de um perfil de macrófagos M1 pode resultar em dano tecidual, que poderia ser minimizado mediante a reprogramação para um perfil menos inflamatório, M2, dessas células. No mesmo sentido, a ativação precoce de um perfil M2 de macrófagos poderia favorecer a proliferação bacteriana, disseminação sistêmica do patógeno, bem como, inflamações crônicas. Dessa forma, o entendimento das vias de sinalização ativadas durante a eferocitose de células apoptóticas infectadas e o perfil de ativação adquirido por essas células poderia auxiliar no tratamento de quadros infecciosos. 


\section{CONCLUSÕES}

1) A fagocitose de células apoptóticas infectadas por S. pneumoniae ou $K$. pneumoniae induz perfis diferentes de ativação de macrófagos. Enquanto a fagocitose de AC-Sp resultou em um perfil misto de polarização, a fagocitose de AC- $K p$ resulta na ativação de macrófagos M1.

2) A ausência de TLR2 favorece o perfil M2 na presença de AC-Sp, porém a ausência de TLR4 há um aumento de marcadores do perfil M1. Na ausência e TLR2 e TLR4 não ocorrem alterações no perfil de ativação de macrófagos que eferocitaram ACKp.

3) A inibição do fator de transcrição NF- $\kappa B$ favoreceu o perfil $M 2$ de ativação de macrófagos que fagocitaram AC-Sp e AC-Kp.

4) A eferocitose de AC-Sp na presença do inibidor de STAT3 favorece o perfil M1. A eferocitose AC- Kp na presença do inibidor de STAT1 favoreceu o perfil M2 de ativação dos macrófagos.

5) O bloqueio do inflamassoma não canônico favorece o perfil M2 em macrófagos que eferocitam AC-Sp.

6) A instilação de AC-Sp in vivo resulta na geração de um microambiente menos inflamatório, enquanto a instilação de $\mathrm{AC}-K p$ induz um padrão misto de resposta com a produção tanto mediadores inflamatórios como anti-inflamatórios no microambiente pulmonar. 


\section{Anexo I}

\section{Geração de macrófagos M0, M1 e M2}

Para a geração dos macrófagos M0, célula medulares extraídas dos fêmures e tíbias de animais foram diferenciadas na presença de M-CSF e GM-CSF por 7 dias. Após esse período, esses macrófagos foram cultivados em meios polarizantes para o perfil M1 (LPS e IFN- $\gamma$ ) e perfil M2 (M-CSF, IL-10 e IL-4), por 24h.

Após esse período, macrófagos M0, M1 e M2 foram coletados e analisados quanto à expressão de genes relacionados a ambos os perfis M1/M2 (Figura 34).

Como esperado, os macrófagos M1 apresentam uma tendência a aumento da expressão de genes sabidamente relacionados ao perfil M1, como $C$ cr7 e $C d 86$, moléculas que tem suas expressões aumentadas durante o processo de ativação celular, quando comparados aos macrófagos M0 que não receberam nenhum estímulo. Macrófagos M2 apresentam alta expressão de genes associados ao perfil M2, como $\arg 1$, fizzl e $c d 206$, relacionados com o metabolismo da ornitina (geração de prolinas, poliaminas e glutamato), remodelamento tecidual e marcador de superfície (receptor de manose), respectivamente, quando comparados aos macrófagos M0 não estimulados (Figura 21).

Por outro lado, macrófagos M2 produzem altas concentrações de IL-10 quando comparados aos macrófagos M0 e baixas concentrações de TNF- $\alpha$ e NO análogas as produzidas por macrófagos M0 (Figura 21). Não detectamos a presença de IL-1 $\beta$ em nenhuma das três condições experimentais avaliadas. Além disso, não houve diferença na produção de TGF- $\beta$ entre as condições experimentais avaliados (dados não mostrados). 
Figura 21. Análise da expressão de genes e mediadores secretados por macrófagos M0/M1/M2.

A)

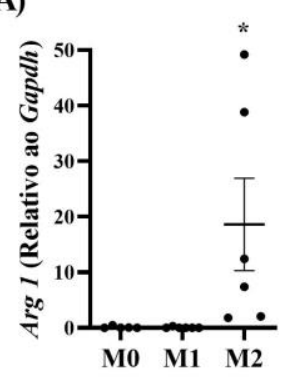

D)

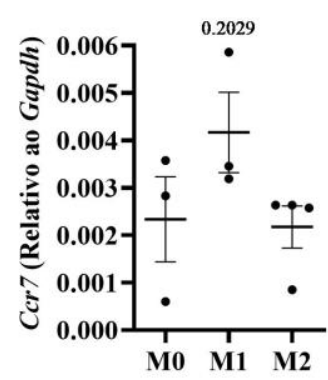

B)

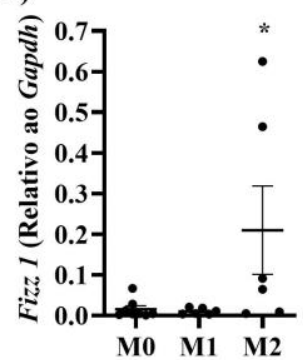

E)

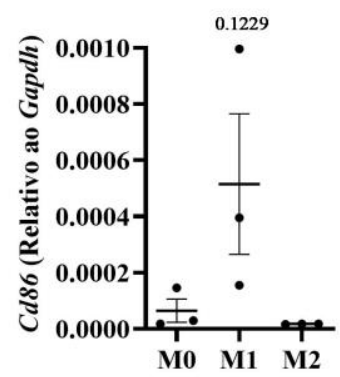

C)

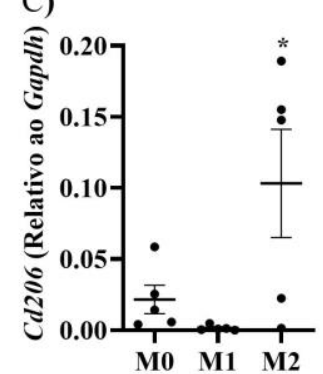

F)

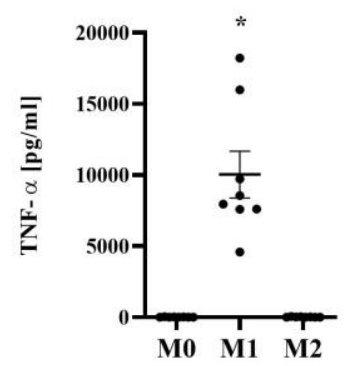

G)

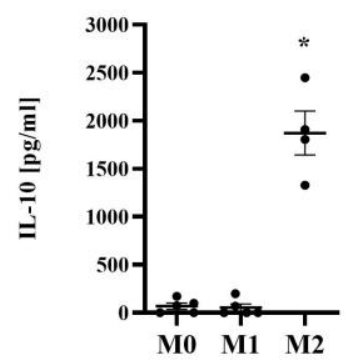

H)

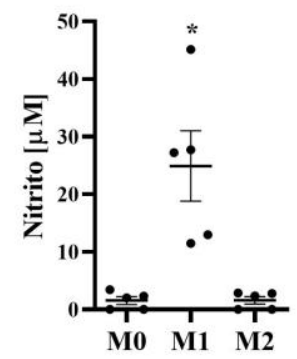

Macrófagos M0, M1 e M2 foram coletados e analisados quanto à expressão de genes relacionados tanto ao perfil M1 quanto ao perfil M2. Macrófagos M0 foram estimulados com IFN- $\gamma$ e LPS para a ativação de macrófagos M1, enquanto o estímulo com IL-4, IL-10 e M-CSF foi adicionado para a ativação de macrófagos M2. Macrófagos M0 foram coletados após os 7 dias de diferenciação e mantidos em meio novo sem estímulos por 24h. A) Argl, B) Fizzl, C) $C d 206$, D) $C c r 7$ e E) $C d 86$. O sobrenadante de cultura de macrófagos M0, M1 e M2 foram coletados e analisados por ELISA e Reação Greiss. F) TNF- $\alpha$, G) IL-10 e H) NO. Resultados de F e G são expressos em $\mathrm{pg} / \mathrm{mL}$ e o resultado de $\mathrm{H}$ é expresso em $\mu \mathrm{M}$. Os dados são a média \pm SEM de 3-8 experimentos realizados independentemente sem replicatas experimentais. * p $<0,05$ vs M0. Valores de p entre 0,5 e 0,05 estão sinalizados no gráfico. 


\section{Geração de neutrófilos a partir da linhagem celular HL-60}

Como fonte de AC, AC-Sp ou AC-Kp optamos pela utilização de uma linhagem celular humana, a HL-60. Essa célula é um promieloblasto que, mediante ao estímulo com dimetilsufóxido (DMSO), é capaz de se diferenciar em células com alta capacidade fagocítica semelhante aos neutrófilos.

Dessa forma, após o tratamento com DMSO por $72 \mathrm{~h}$, o perfil de morte celular das células submetidas ao tratamento de diferenciação foi avaliado, de modo a garantir que a porcentagem de DMSO utilizada para a diferenciação a neutrófilos não induziria altas porcentagens de morte celular na cultura basal.

Para determinar o perfil de morte celular, optamos pela técnica de citometria de fluxo utilizando anexina V, proteína que se liga a molécula de PS exposta na superfície da membrana celular durante o processo apoptóticos, e a molécula de 7 aminoactinomycin $\mathrm{D}$ (7AAD), que se intercala ao DNA das células quando a membrana celular é rompida durante o processo de morte por necrose.

Neutrófilos cultivados na presença de 1,2\% de DMSO por 72h apresentam uma baixa taxa de apoptose basal, cerca de $20 \%$, sendo que dessas, aproximadamente $16 \%$ das células se encontravam no estágio de apoptose precoce (anexina V positiva e 7AAD negativa) enquanto apenas cerca de 4,5\% das células se mostraram apoptóticas tardias (positivas tanto para anexina $\mathrm{V}$ quanto para 7AAD). Em torno de $80 \%$ de células mostraram-se viáveis, ou seja, negativas para anexina V e 7ADD. Não detectamos a presença de células necróticas na cultura após o estímulo com DMSO (Figura 22).

Embora tenhamos encontrado uma pequena porcentagem de células em processo apoptótico, essa quantidade não interfere na capacidade fagocítica final dessas células e nem no processo futuro de apoptose no qual essas células serão submetidas como podemos constatar nos experimentos seguintes. 
Figura 22. Apoptose basal de neutrófilos gerados a partir das células HL-60.

A)

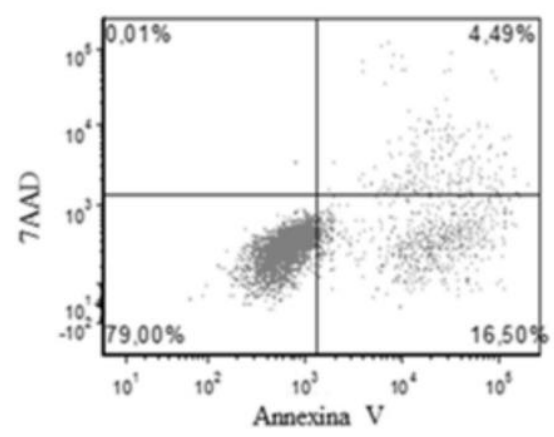

B)

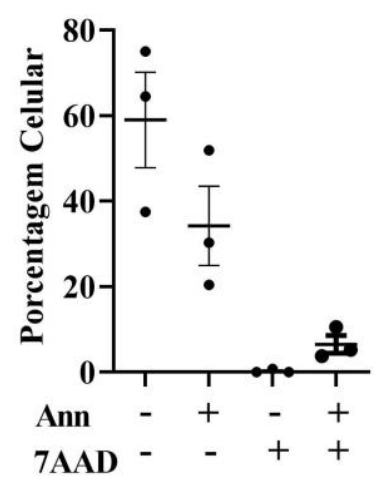

Os neutrófilos foram coletados após 72h de cultivo em meio DMEM com 10\% de SBF e 1,2\% de DMSO e analisados por citometria de fluxo para determinação do perfil apoptótico basal. A) Dot Plot representativo de Anexina V vs 7AAD. B) Somatória das replicatas experimentais independentes. Os resultados são referentes a 3 experimentos realizados individualmente. 


\section{Determinação da concentração de CFSE utilizada para marcação bacteriana}

Uma vez determinada a porcentagem de morte induzida pela diferenciação com DMSO, a próxima etapa foi avaliar o índice de fagocitose de $S$. pneumoniae e $K$. pneumoniae pelos neutrófilos gerados a partir da linhagem celular HL-60. Para isso, as duas cepas bacterianas foram marcadas com diferentes concentrações de CFSE de acordo com as especificações do fabricante. O CFSE é um corante celular que não altera a viabilidade e funções efetoras das células analisadas.

Como podemos observar pela análise de citometria de fluxo, tanto para o $S$. pneumoniae (Figura 23) quanto para a K. pneumoniae (Figura 24), a concentração de CFSE de $5 \mu \mathrm{M} / 10^{8} \mathrm{UFC} / \mathrm{mL}$ foi suficiente para marcar aproximadamente $100 \%$ das cepas bacterianas, sendo, portanto, a concentração de escolha para os experimentos subsequentes. 
Figura 23. Marcação de Streptococcus pneumoniae com diferentes concentrações de CFSE.
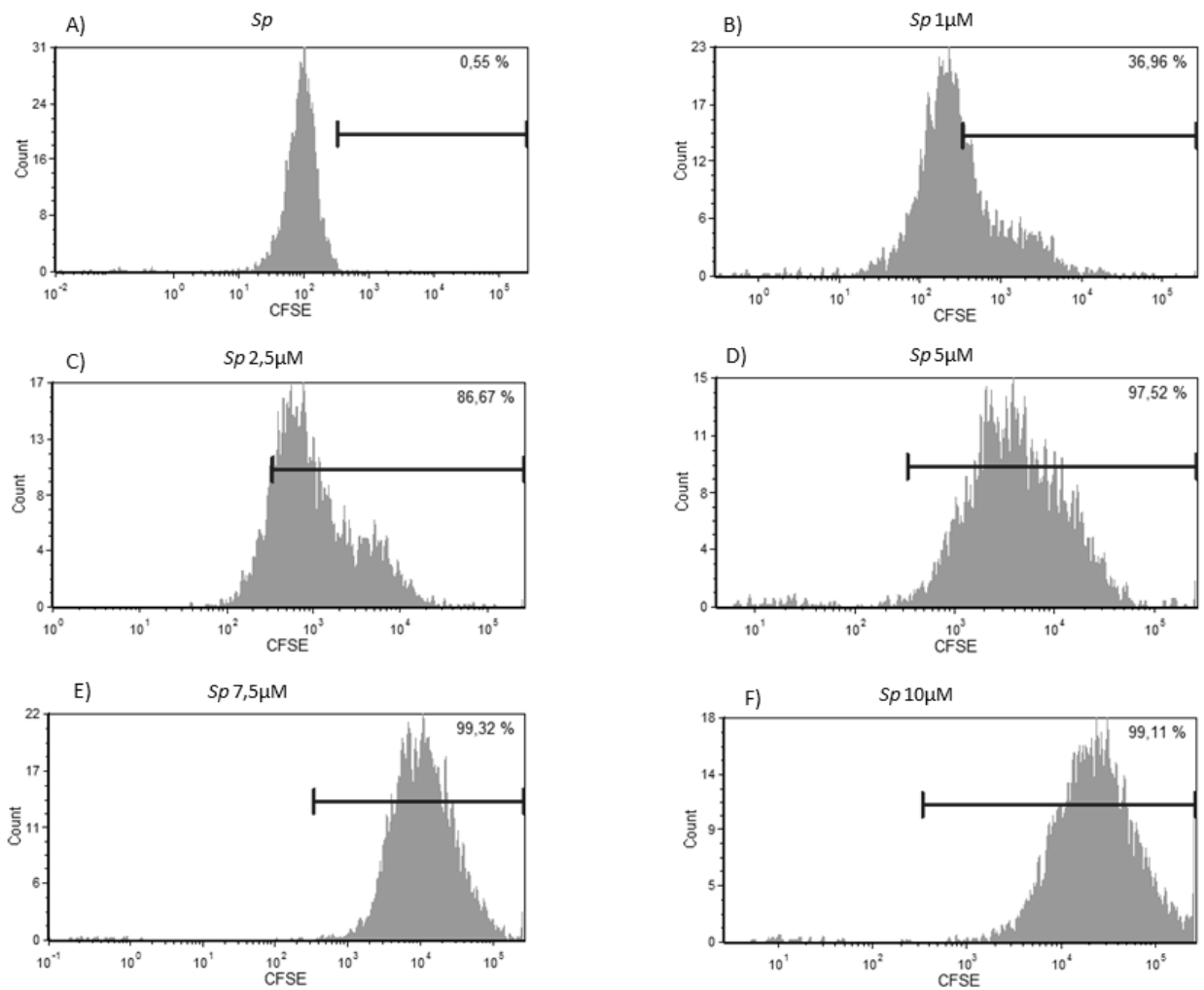

Cerca de $10^{8}$ de unidades formadoras de colônia (UFC) de S. pneumoniae forma incubadas com as seguintes concentrações de CFSE, A) PBS $1 \mathrm{x}$; B) $1 \mu \mathrm{M}$; C) $2,5 \mu \mathrm{M}$; D) $5 \mu \mathrm{M}$; E) $7,5 \mu \mathrm{M}$; F) $10 \mu \mathrm{M}$, por 20 minutos a $37^{\circ} \mathrm{C}$ segundo as especificações do fabricante. Os resultados são referentes a um experimento representativo de dois experimentos individuais. 
Figura 24. Marcação de Klebsiella pneumoniae com diferentes concentrações de CFSE.
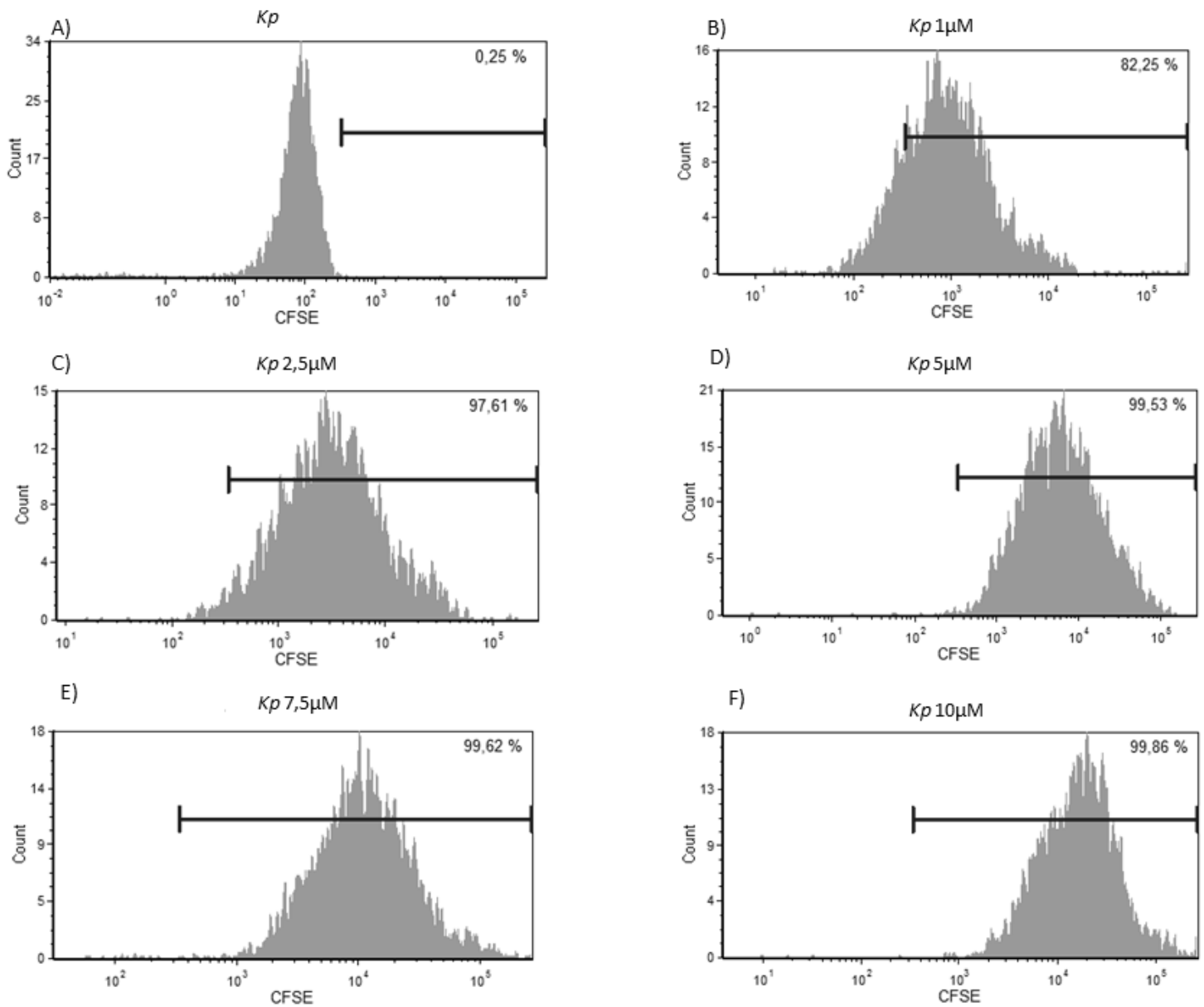

Cerca de $10^{8}$ UFC de K. pneumoniae forma incubadas com as seguintes concentrações de CFSE, A) PBS $1 \mathrm{x}$; B) $1 \mu \mathrm{M}$; C) $2,5 \mu \mathrm{M}$; D) $5 \mu \mathrm{M}$; E) $7,5 \mu \mathrm{M}$; F) $10 \mu \mathrm{M}$, por 20 minutos a $37^{\circ} \mathrm{C}$ segundo as especificações do fabricante. Os resultados são referentes a um experimento representativo de dois experimentos individuais. 


\section{Perfil de ativação de macrófagos M0 após a cocultura com células viáveis ou} células apoptóticas ou células necróticas

Embora a maior porcentagem de células adicionadas a cocultura com macrófagos M0 para eferocitose sejam células apoptóticas, infectadas ou não infectadas, também é adicionado a essa cultura quantidades variáveis de células viáveis e células necróticas (Figura 4).

Portanto, avaliamos o efeito da presença dessas células na cocultura com macrófagos M0. Utilizamos as células HL-60 não infectadas como fonte de células viáveis. Como fonte de células necróticas, HL-60 foram submetidas ao processo de congelamento e descongelamento consecutivo (176), por três vezes, em meio não apropriado, solução salina $1 \mathrm{x}$, para que a membrana das células se rompessem, característico de células necróticas.

Macrófagos cultivados tanto na presença de células necróticas como de células viáveis apresentam uma tendência a aumento na expressão de arginase 1 e uma diminuição na expressão do receptor de manose (CD206) quando comparados com a eferocitose de AC. Não ocorreram mudanças na expressão dos genes fizzl e ccr7 (Figura 25).

Além da expressão gênica, avaliamos também o perfil de mediadores produzidos após o contato de macrófagos M0 com células necróticas e células viáveis. O cocultivo de macrófagos tanto com células necróticas como com células viáveis não induziu diferenças significativas na produção de óxido nítrico quando comparado à condição de cultivo de macrófagos M0 com células apoptóticas estéreis. Por outro lado, a incubação desses tipos celulares com macrófagos M0 resultou em uma menor produção de IL-10, quando comparada a condição de cocultivo de macrófagos com AC (Figura 25).

As citocinas IL-1 $\beta$ e TNF- $\alpha$ não foram detectadas dentro do limite de confiabilidade dos kits de ELISA utilizados em nenhuma das três condições experimentais analisadas. Além disso, a produção de TGF- $\beta$ manteve-se semelhante entre os grupos experimentais testados (dados não mostrados).

Tanto os resultados de avaliação da expressão de genes relacionados ao perfil M1/M2 quanto à quantificação de mediadores liberados durante o cultivo de macrófagos M0 com células necróticas e viáveis serão repetidos posteriormente para a 
publicação dos resultados em periódico indexado. Entretanto, de maneira geral, podemos concluir que o perfil de ativação de macrófagos M0 cultivados na presença de células viáveis ou células necróticas é diferente do perfil de ativação de macrófagos M0 que eferocitam células apoptóticas estéreis, de forma que as pequenas porcentagens dessas células adicionadas à cultura durante a eferocitose de $\mathrm{AC}, \mathrm{AC}-\mathrm{Sp}$ e $\mathrm{AC}-\mathrm{Kp}$ não teriam um impacto no perfil de ativação de macrófagos M0. 
Figura 25. Perfil de expressão gênica e de mediadores secretados por macrófagos cultivados na presença de células apoptóticas, células viáveis e células necróticas.

A)

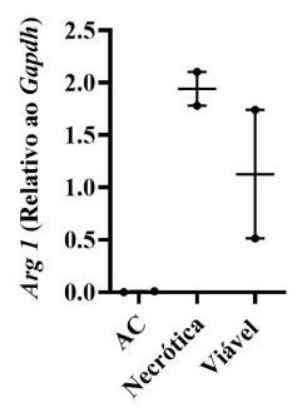

D)
B)

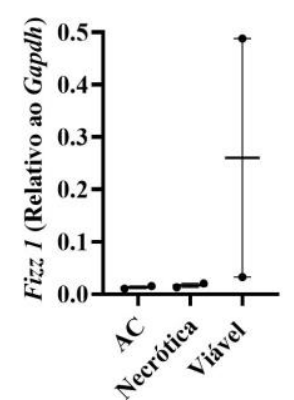

C)

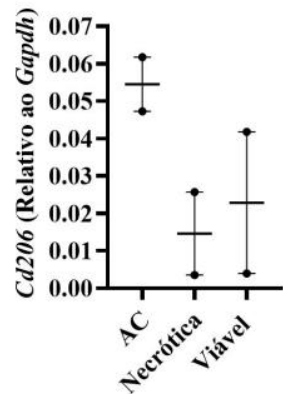

E)

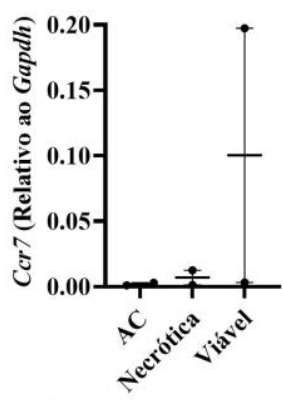

F)

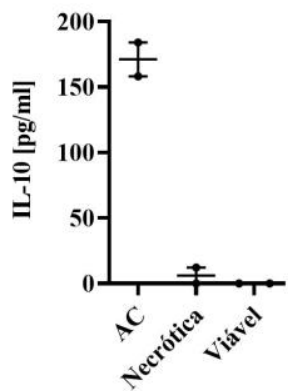

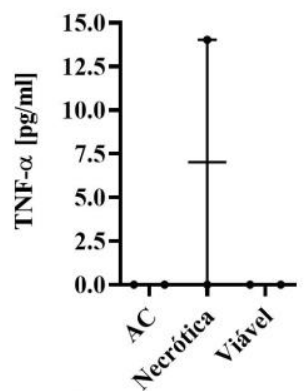

G)

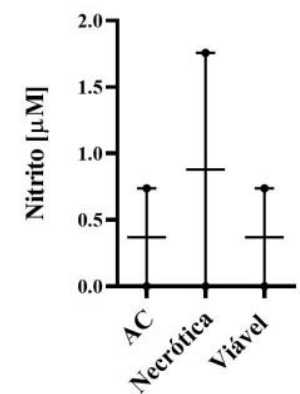

Macrófagos M0 foram cocultivados na presença de AC, células necróticas (Necrótica) ou células viáveis (Viável) na proporção de 1 macrófagos M0 para 3 células testadas (1M0:3células), por $2 \mathrm{~h}$. Em seguida, a cultura foi lavada e incubada com meio novo por subsequentes $24 \mathrm{~h}$. Após esse período as células foram coletadas e a expressão dos genes foi analisada. A) Arg 1, B) Fizz1, C) Cd206 e D) Ccr7. Os sobrenadantes de cultura foram coletados e avaliados quanto à presença de diferentes mediadores. E) TNF- $\alpha$, F) IL-10, G) NO. Resultado de E-F são expressos em $\mathrm{pg} / \mathrm{mL}$ e o resultado de $\mathrm{G}$ é expresso em $\mu \mathrm{M}$. Média SEM da quantificação de dois experimentos realizados individualmente sem replicatas experimentais. 
5. Perfil de ativação de macrófagos M0 após a fagocitose de S. pneumoniae ou $K$. pneumoniae

Uma possível crítica em nosso protocolo experimental seria a presença de bactérias livres e viáveis na cultura durante a etapa de eferocitose das células apoptóticas infectadas. Dessa forma, macrófagos M0 foram cultivados apenas na presença de bactérias livres (S. pneumoniae ou K. pneumoniae) em MOI de 30, por $2 \mathrm{~h}$, e posterior análise da expressão de genes relacionados tanto ao perfil M1 quanto ao perfil M2 de ativação dos macrófagos bem como análise dos mediadores liberados no sobrenadante de cultura celular após a fagocitose.

A fagocitose de $S p$ e $K p$ induziu um aumento na expressão de Argl quando comparado aos macrófagos M0 cultivados apenas com meio de cultura. Além disso, uma tendência no aumento da expressão de Fizz1 e Cd206 foi observada durante a fagocitose de ambas as cepas bacterianas. Não houve diferenças na expressão de $C c r 7$ nas condições avaliadas (Figura 26).

A avaliação do perfil de mediadores produzidos após a fagocitose de $S p$ e $K p$ demonstrou que ambas as cepas bacterianas induziram uma alta produção de óxido nítrico não observada em macrófagos incubados apenas com meio de cultura (Figura 26).

A fagocitose de $S p$ não induziu a produção de quantidades significativas de TNF- $\alpha$ quando comparado a macrófagos M0. Além disso, observamos uma tendência a aumento na produção de IL-1 $\beta$ após a fagocitose de $S p$ (Figura 26). Por outro lado, após a fagocitose de $K p$, observou-se uma tendência a aumento na produção de citocinas inflamatórias como TNF- $\alpha$ e IL-1 $\beta$. A fagocitose de ambas as cepas bacterianas não alterou a produção da citocina anti-inflamatória IL-10 (Figura 26). 
Figura 26. Perfil de expressão gênica e de mediadores secretados por macrófagos M0 que fagocitaram S. pneumoniae ou K. pneumoniae.
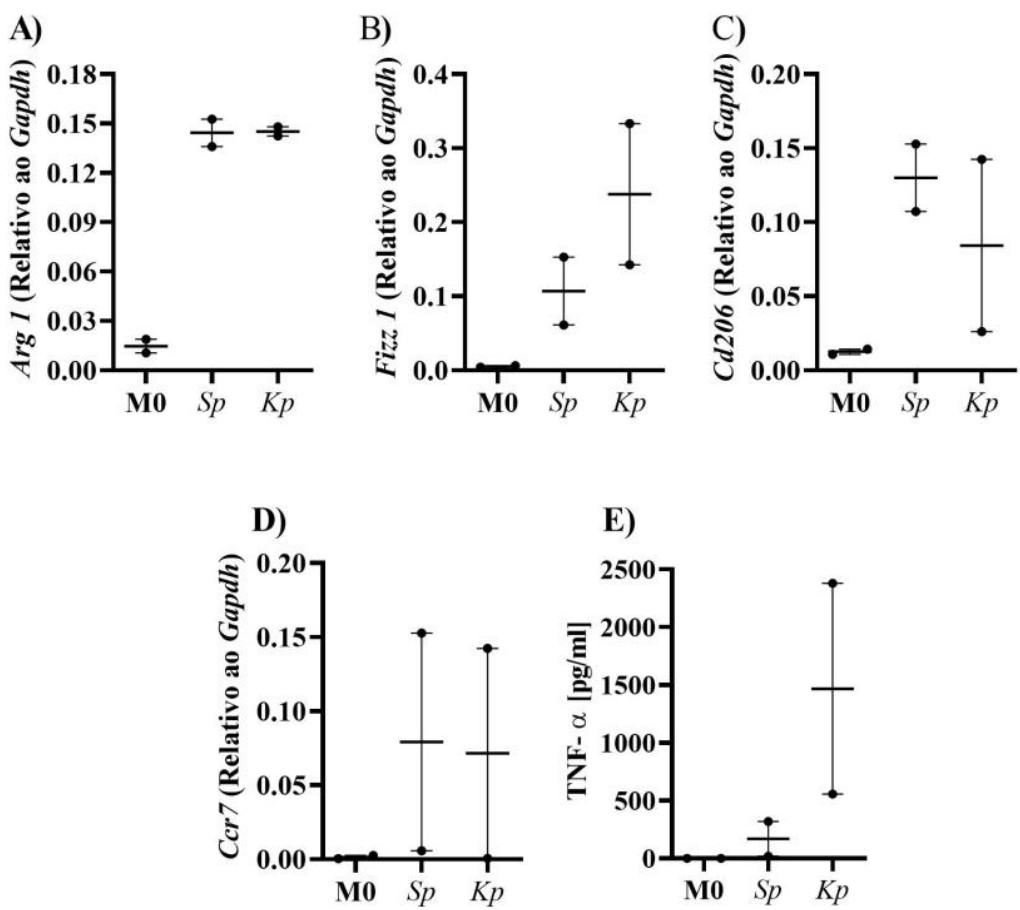

F)

G)
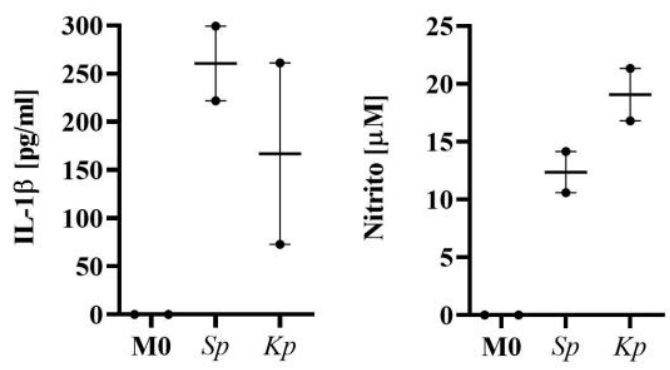

Macrófagos M0 foram cultivados na presença de $S$. pneumoniae $(S p)$ ou $K$. pneumoniae $(K p)$ em MOI de 30, por $2 \mathrm{~h}$. Em seguida, a cultura foi lavada e incubada com meio novo por subsequentes $24 \mathrm{~h}$. Após esse período as células foram coletadas e a expressão dos genes foi analisada. A) Argl, B) Fizzl, C) Cd206 e D) Ccr7. Os sobrenadantes de cultura foram coletados e avaliados quanto à liberação dos diferentes mediadores. E) TNF- $\alpha, \mathbf{F})$ IL-1 $\beta$, G) IL-10 e H) NO. Resultados de E-G são expressos em $\mathrm{pg} / \mathrm{mL}$ e o resultado de $\mathrm{H}$ é expresso em $\mu \mathrm{M}$. Resultados referentes a dois experimentos sem replicatas experimentais. 
CAPÍtulOO 2. 


\section{MicroRNA-21 prejudica as respostas imune do hospedeiro contra Staphylococcus aureus}

\section{RESUMO}

Células residentes dos tecidos e células recrutadas para o foco infeccioso são as responsáveis pelas primeiras respostas imunológicas frente à infecção causada por $S$. aureus. O controle da infecção é regulado por um balanço entre a resposta inflamatória e eliminação bacteriana, evitando o dano tecidual. MicroRNAs (miRNAs) são pequenos RNAs não codificados que regulam a expressão gênica. Diferentes células do sistema imune expressam miRNAs capazes de regular a produção de mediadores próinflamatórios e anti-inflamatórios, importantes para as respostas contra patógenos. Nossos dados demonstram que a infecção por $S$. aureus resulta no aumento da expressão de miR-21 após 24h. A infecção subcutânea por S. aureus em animais que não expressam miR-21 em células mielóides (miR2 $1^{\Delta \text { myel })}$ resulta na formação de lesões mais circunscritas, com baixa carga bacteriana, aumento da expressão de genes relacionados ao perfil de resolução e deposição de colágeno na cápsula do abscesso quando comparado a infecção em animais selvagens (WT). A ausência de miR-21 favoreceu a expressão de MyD88 nas biópsias de animais infectados. Animais tratados com pepetídeo inibidor de MyD88 e antagomiR-21 não apresentam a melhora das respostas dos hospedeiros e eliminação bacteriana observadas em animais tratados apenas com antagomiR-21. Assim, nossos resultados sugerem que a inibição da expressão de miR-21 favorece a sinalização de MyD88 desencadeando uma resposta inflamatória controlada necessária para a resolução da infecção de pele causada pelo $S$. aureus.

Palavras-chave: microRNA-21, Staphylococcus aureus, macrófagos e MyD88. 


\section{INTRODUÇÃO}

Staphylococcus aureus é uma bactéria Gram-positiva encontrada na microbiota da pela humana relacionada tanto a infecções oportunistas que ocorrem de forma assintomática (177) quanto a quadros de bacteremia associados com alta taxa de mortalidade, $20-30 \%$ (178). Nos últimos anos, o aparecimento de diferentes cepas de $S$. aureus resistente aos antibióticos disponíveis como as cepas de S. aureus resistente à meticilina (MRSA) estão associadas às infecções de pele, endocardites, osteomielites e sepse (177).

Células residentes dos tecidos e células recrutadas para o foco infeccioso são as responsáveis pelas primeiras respostas imunológicas frente à infecção causada por $S$. aureus. Os macrófagos residentes dos tecidos acometidos juntamente com queratinócitos reconhecem os patógenos por meio dos PAMP via PRR, como receptores do tipo toll e receptores scavenger como MARCO e CD36 (179-181), dando início a formação de um abscesso (182). O reconhecimento do patógeno via interação entre PAMPs e PRRs promove a liberação de mediadores como citocinas (IL-1 $\alpha$, IL-1 $\beta$, IFN$\gamma$, TNF- $\alpha$, IL-17A, IL-17F e IL-22), quimiocinas (CXCL1, CXCL2, CXCL9, CXCL10, CXCL11, CCL27 e CCL20) e mediadores lipídicos (LTB 4 e PGE 2 ), que contribuem para o influxo de monócitos e neutrófilos para o tecido infectado (181-185).

Os neutrófilos são indispensáveis para o controle da infecção, uma vez que essas células são recrutadas rapidamente após o inicio da infecção e atuam tanto na fagocitose da bactéria como na produção de espécies reativas do oxigênio e nitrogênio e liberação de NETs (Neutrophil Extracellular Traps) que favorece a eliminação do patógeno (182, 185). Por outro lado, macrófagos, além de colaborarem com a aliminação bacteriana via fagocitose, também são responsáveis pela eliminação de células mortas (processo chamado de eferocitose) e, juntamente com células do tecido, produzem fibrina e colágeno importantes para a formação de um abscesso $(182,185)$.

Os abscessos causados pela infecção por $S$. aureus podem ser formados nos mais diferentes tecidos, como pele $(186,187)$, rins (188) e cérebro (189), entre outros e, embora os tecidos possuam características órgão-dependente a estrutura do abscesso e etapas de formação são semelhantes (182). As regiões centrais do abscesso são 
compostas por uma grande quantidade de neutrófilos vivos, apoptóticos e necróticos, debris teciduais, fibrina bem como bactérias viáveis. A maturação do abscesso é associada à proliferação de fibroblastos, reparo tecidual e formação de uma cápsula fibrosa na periferia do abscesso (182). Amy Aldrich e Tammy Kielian demonstraram que macrófagos M2 estão colocalizados ao longo da parede de abscessos cerebrais causados por S. aureus colaborando para a formação destes (190).

Macrófagos são células que possuem alto grau de plasticidade. Atualmente, são descritas ao menos duas populações, macrófagos M1 e macrófagos M2. O estado de polarização desse fagócito direciona suas funções efetoras. Enquanto macrófagos M1 são descritos como pró-inflamatórios por produzir grandes quantidades de citocinas inflamatórias e possuírem elevada capacidade de englobamento e eliminação de patógenos (62, 191-193), macrófagos M2 são descritos como produtores de mediadores anti-inflamatórios como IL-10 e TGF- $\beta$. Além disso, a população de macrófagos M2 exibe alta capacidade de proliferação e remodelação tecidual, promovendo a melhor cicatrização de lesões devido ao metabolismo da arginase que é associado à produção de colágeno e matriz extracelular (76, 194-197).

Além disso, macrófagos M2 expressam receptores eferocíticos, como CD36 e SR-A1 (198, 199). Estudos demonstraram que CD36 possui um importante papel no reconhecimento de $S$. aureus, uma vez que atua juntamente com o receptor TLR2 reconhecendo componentes da parede da bactéria, como os diacilglicerídeos, promovendo a fagocitose microbiana e a produção de citocinas, TNF- $\alpha$ e IL-12, que auxiliam no controle bacteriano $(200,201)$. CD36 também contribui na resolução da infecção via eferocitose evitando a dermonecrose gerada pelo acúmulo de células mortas no tecido (198).

As respostas inflamatórias desencadeadas pela presença do S. aureus e pela produção de grande quantidade de mediadores liberados em respostas ao patógeno devem ser bem controladas tanto em nível de transcrição quanto de tradução gênica de modo a se evitar o dano tecidual. Os microRNAs (miRNAs) são pequenos RNAs não codificados ( 18-25 pares de bases) indispensáveis para a regulação da expressão gênica através da inibição da tradução gênica ou por induzir a desestabilização de mRNA maduros e consequente degradação (202). 
As infecções por $S$. aureus são associadas com a modulação da expressão de diversos miRNAs tanto in vitro utilizando macrófagos murinos e humanos quanto em modelos de infecção pulmonar, de pele e de glândulas mamárias (203-207). Porém, nada se tem descrito correlacionando a presença de miR-21 com infecções de pele causadas por MRSA.

O miR-21 é o microRNA mais abundante em macrófagos (208) e está associado a polarização dessas células a um perfil M2 (209). Xue e colaboradores demonstraram que miR-21 regula negativamente a via de sinalização de MyD88 dependente de TLR4 em macrófagos RAW 264.7 infectados com o Bacillus Calmette-Guerin (210).

MyD88 é uma proteína adaptadora essencial tanto para a sinalização decorrente da ativação de TLR, exceto TLR3, quanto de receptores de citocinas da família da IL-1 (211, 212). Esses receptores interagem com a molécula de MyD88 desencadeando a

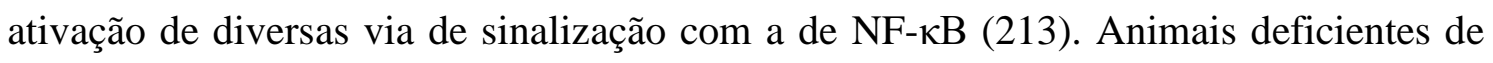
MyD88 quando estimulados com diferentes ligante de TLRs como a LPS, peptidoglicanos, lipoproteínas, sequências de DNA metilado, dsRNA e flagelina não produzem citocinas inflamatórias como TNF- $\alpha$ e IL-12 (214). Diversos estudos demonstram que a sinalização MyD88 é importante na regulação da inflamação durante infecções causadas por diversos patógenos, entre eles S. aureus (215).

Putnam e colaboradores demonstraram que tanto a molécula de MyD88 quanto o receptor de IL-1 são imprescindíveis para o controle da carga bacteriana durante quadros de osteomielite causados por $S$. aureus (216). Além disso, animais deficientes de MyD88 são mais susceptíveis a infecção de pele causadas por essa bactéria (217), uma vez que a ativação da via de sinalização de MyD88 culmina no recrutamento de neutrófilos para o foco infeccioso, colaborando para o controle da bacteremia (218).

Entretanto, até o momento, não há estudos demonstrando a influência de miR-21 na regulação das respostas do hospedeiro frente à infecção de pele por S. aureus. 


\section{OBJETIVO}

O objetivo de trabalho foi avaliar os mecanismos pelos quais o miR-21 regula as respostas do hospedeiro durante as infecções de pele causadas pelo Staphylococcus aureus. 


\section{MATERIAL E MÉTODOS}

\subsection{Animais}

Camundongos selvagens com background em C57BL/6, miR21 ${ }^{\text {smyel }}$ (animais deficientes para miR-21 em células mielóides, background em C57BL/6) ou MMDTR (o cruzamento de Csf1rL ${ }^{\text {LsL-DTRmCherry }}$ com o camundongo LysM ${ }^{\text {cre }}$ gerou o animal Monocyte-macrophage DTR-mCherry - background em C57BL/6), com idade entre 510 semanas, foram mantidos de acordo com o guia de boas práticas experimentais de animais do NIH (National Institutes of Health) com aprovação do IACUC (Institution Animal Care and Use Committee) da Universidade de Vanderbilt, número M160021501.

\subsection{Cultivo de Staphylococcus aureus resistente à meticilina (MRSA)}

No trabalho relacionado a esse capítulo da tese utilizamos a cepa de MRSA bioluminescente USA 300 (NRS384 lux) doada pelo Dr. Roger Plaut (Food and Drug Administration, Silver Spring, Maryland, USA) (219). O estoque bacteriano foi mantido em alíquotas congeladas à $-80^{\circ} \mathrm{C}$. As alíquotas de MRSA foram descongeladas e cultivadas em $10 \mathrm{~mL}$ de TSB à $37^{\circ} \mathrm{C}$ e sob agitação por $18 \mathrm{~h}$. No dia seguinte, a cultura bacteriana foi diluída em $10 \mathrm{~mL}$ de meio TSB novo na proporção de 1:100 e incubada por $3 \mathrm{~h}$ à $37^{\circ} \mathrm{C}$ e agitação. Para determinar a densidade bacteriana, a cultura foi diluída na proporção de $1: 10$, a densidade óptica $(\lambda=600 \mathrm{~nm})$ foi avaliada e comparada a uma curva de crescimento bacteriano previamente padronizada $\left(\mathrm{OD}_{600}\right.$ no eixo y vs UFC/mL no eixo $\mathrm{x}$ ). Em tubos de 1,5 mL, $1 \times 10^{9}$ bactérias foram centrifugadas a 15.000 RPM por 10 minutos a $4^{\circ} \mathrm{C}$. Em seguida, o sobrenadante foi desprezado, as bactérias foram ressupensas em $1 \mathrm{~mL}$ de PBS 1x e o tubo foi centrifugado novamente. Essa etapa foi repetida duas vezes. Após a lavagem final, as bactérias foram diluídas para a concentração final de $1 \times 10^{8} \mathrm{MRSA} / \mathrm{mL}$. A concentração dos inóculos utilizados para a infecção de pele dos animais foi confirmada em placas de TSA (tryptic soy agar) a partir de diluições seriadas na base 10. As placas de TSA foram incubadas por 18h à $37^{\circ} \mathrm{C}$ e $5 \% \mathrm{CO}_{2}$. Após esse período, as UFC foram contadas para a determinação a carga real do inóculo. 


\subsection{Modelo de infecção de pele por MRSA}

Um dia antes do experimento, os pelos das costas dos animais foram aparados utilizando um aparador de pelos. Em seguida, a pele foi completamente depilada utilizando creme depilatório por 20 segundos, seguida da limpeza da área com gaze úmida com água e gaze seca para a retirada completa do creme depilatório. No dia do experimento, a pele dos animais foi desinfectada com álcool $70 \%$ e $50 \mu \mathrm{L}$ do inóculo na concentração de $1 \times 10^{8}$ MRSA/mL foi injetado utilizando agulha de $30 \mathrm{G} 1 / 2$. As lesões e tamanho dos abscessos foram monitorados diariamente utilizando um paquímetro. A área do abscesso foi determinada pela equação [área $=(\pi / 2) \times$ comprimento $\times$ largura] $(220)$.

\subsection{Coleta de biópsia na pele dos animais}

As biópsias foram coletadas em diferentes momentos após a infecção, variando de 6 horas a 9 dias de infecção. Para a coleta, os animais foram eutanasiados e as biópsias com aproximadamente $8 \mathrm{~mm}$ de diâmetro foram coletadas. Os tecidos obtidos foram divididos em 4 partes para as seguintes análises: carga bacteriana, produção de citocinas, qRT-PCR e histologia.

\subsection{Determinação da carga bacteriana nas lesões de pele}

Para a determinação da carga bacteriana, os tecidos foram homogeneizados em $200 \mu \mathrm{L}$ de TSB com o auxílio de uma haste e plaqueados em placas de TSA em diluições seriadas na base 10 . Após $18 \mathrm{~h}$ de incubação das placas à $37^{\circ} \mathrm{C}$ e $5 \% \mathrm{CO}_{2}$, as UFC foram determinadas utilizando a equação: UFC $=$ [(quantidade de colônias) $\mathrm{x}$ (fator de diluição da amostra)] / peso do tecido em mg. Os resultados são expressos em média \pm SEM de UFC/mg de tecido.

\subsection{Quantificação de citocinas}

Os tecidos foram homogeneizados em $300 \mu \mathrm{L}$ de tampão de TNE [100 mM Tris$\mathrm{HCl}$ (pH 7.5), $0.5 \mathrm{mM}$ EDTA, $150 \mathrm{mM} \mathrm{NaCl}]$ na presença de inibidor de protease $1 \mathrm{x}$ (Sigma) com o auxílio de uma haste e, em seguida, centrifugados para remoção dos debris celulares. Os analitos foram avaliados no sobrenadante (diluição de 1:2) utilizando a técnica de multiplex (R\&D Systems) como descrito pelo fabricante usando 
Bio-Rad Bio-Plex MAGPIX multiplex ou pela técnica de ELISA (diluição 1:4) seguindo as recomendações do fabricante dos kits de detecção (BioLegend, San Diego, CA, EUA). Os resultados são expressos como média \pm SEM de citocinas em pg/mg de tecido.

Tabela 2. Painel de beads magnéticas utilizadas no ensaio de Multiplex

\begin{tabular}{|c|c|}
\hline Analito & Região de análise \\
\hline CCL2/MCP-1/JE & (BR 18) \\
\hline CCL4/MIP-1 $\beta$ & (BR 51) \\
\hline CCL7/MARC & (BR 39) \\
\hline CCL8/MCP-2 & (BR 38) \\
\hline CXCL1/KC & (BR 13) \\
\hline CXCL2/MIP-2 & (BR 20) \\
\hline ICAM-1 & (BR 35) \\
\hline IFN- $\gamma$ & (BR 33) \\
\hline IL-1 $\alpha$ & (BR 47) \\
\hline IL-1 $\beta$ & (BR 19) \\
\hline IL-12p70 & (BR 15) \\
\hline IL-33 & (BR 43) \\
\hline MMP-12 & (BR 73) \\
\hline MMP-8 & (BR 61) \\
\hline MMMP-9 & (BR 62) \\
\hline P-Selectina & (BR 46) \\
\hline RAGE & (BR 78) \\
\hline TIM-1/KIM-1 & (BR 72) \\
\hline VEGF & (BR 21) \\
\hline
\end{tabular}

\subsection{Extração de RNA, geração de cDNA e qRT-PCR}

As biopsias de pele foram homogeneizadas em $400 \mu \mathrm{L}$ de tampão de lise (Buffer RLT; QIAGEN) com $\beta$ - mercaptoetanol utilizando uma haste. As amostras foram centrifugadas e o sobrenadante foi adicionado a um tubo novo contendo $400 \mu \mathrm{L}$ de isopropanol, seguida de incubação a temperatura ambiente por 10 minutos. Na próxima etapa, as amostras foram centrifugadas, o sobrenadante desprezado e ressuspendidas em $800 \mu \mathrm{L}$ de etanol 75\%. Após uma nova centrifugação, todo o álcool foi descartado e evaporado seguido de adição de $50 \mu \mathrm{L}$ de água ultrapura. Uma vez obtido o RNA, esse 
foi utilizado para a produção de cDNA com o kit BioRad iScript segundo as recomendações do fabricante. As amostras de cDNA foram utilizadas para o ensaio de PCR em tempo real. A expressão gênica foi determinada pela amplificação com primers específicos com homologia para camundongos e a quantificação foi feita utilizando Sybr Green (BioRad). A expressão relativa dos genes foi calculada utilizando o método de $2^{-\Delta \mathrm{Ct}}$.

Tabela 3. Primers utilizados para a análises das biópsias de pele

\begin{tabular}{|c|c|c|}
\hline Primer & & \\
\hline $\operatorname{miR21}$ & 5'- ACACTCCAGCTGGGTAGCTTATCAGACTGA-3' & 5'- TGGTGTCGTGGAGTCG-3' \\
\hline MyD88 & 5'- CTGTAAAGGCTTCTCGGACTC-3' & 5'-GTGAGGATATACTGAAGGAGCTG-3' \\
\hline Chi3ll & 5'- CATCAAAGCCATAAGAACGC-3' & 5'-CCAGAAACACCAACCTGAAGA-3' \\
\hline$C d 36$ & 5'-GGACATACTTAGATGTGGAACCCATA-3' & 5'- TGTTGACCTGCAGTCGTTTTG-3' \\
\hline Col3al & 5'-GACCAAAAGGTGATGCTGGACAG-3' & 5'-CAAGACCTCGTGCTCCAGTTAG-3' \\
\hline Actinb & 5'-GATTACTGCTCTGGCTCCTAG-3' & 5'-GACTCATCGTACTCCTGCTTG-3' \\
\hline
\end{tabular}

\subsection{Análises histopatológicas}

As biópsias foram fixadas em paraformaldeído $4 \%$ durante $18 \mathrm{~h}$ e, em seguida, transferidas para uma solução de etanol 70\%. A preparação dos blocos de parafina, cortes histológicos e as seguintes marcações: hematoxilina e eosina, tricromo Masson para a visualização de colégeno e F4/80 para a determinação da população de macrófagos nas biópsias foram feitas pelo centro de histologia da Universidade de Vanderbilt - TPSR (Translation Pathology Resource Core). As imagens das seções dos tecidos foram visualizadas e adquiridas usando Nikon Eclipse Ci e Nikon Ds-Qi2 (Nikon, Tokyo, Japan).

\subsection{Depleção de neutrófilos}

A depleção de neutrófilos foi realizada utilizando um anticorpo bloqueador com especificidade para Ly6G (clone 1A8) e IgG controle (BioXcell) em tampão de diluição BioXcell pH 7,0. Os anticorpos foram administrados via intraperitoneal $18 \mathrm{~h}$ antes da 
infecção cutânea por MRSA descrita no item 3.3. As biópsias foram coletas após 24 h de infecção e processadas de acordo com a descrição do item 3.7.

\subsection{Depleção de macrófagos}

Os monócitos e macrófagos dos animais MMDTR expressam o receptor da toxina da diftérica (DTR) associado à proteína de fusão mCherry, permitindo-nos a confirmação da depleção específica de macrófagos em camundongos tratados com a toxina diftérica (DT) por citometria de fluxo. Para a depleção de macrófagos, os camundongos MMDTR foram tratados com $100 \mathrm{ng}$ de DT ou PBS (veículo controle) durante três dias consecutivos antes da inoculação cutânea de MRSA como descrito previamente no item 3.3. As biópsias foram coletas após 24 h de infecção e processadas de acordo com a descrição do item 3.7 (Figura 27). 
Figura 27. Protocolo de depleção de macrófagos em animais MMDTR

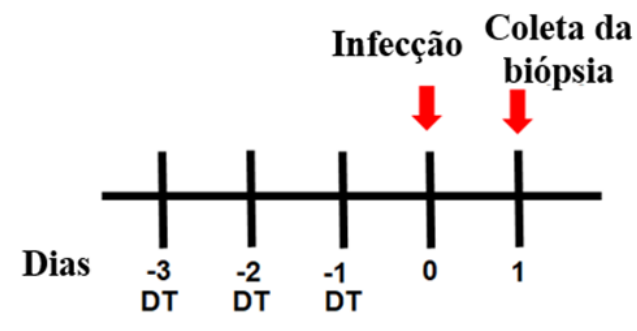

Animais MMDTR foram tratados com 100 ng de DT ou PBS (veículo controle) durante três dias consecutivos antes da inoculação cutânea de MRSA. 


\subsection{Preparação das pomadas}

Para os experimentos de inibição de miR-21 foram preparadas 2 pomadas diferentes contendo: $i$ ) antagomiR-21 e ii) antagomiR controle. Para o experimento de inibição simultânea de miR-21 e MyD88 foram preparadas 4 pomadas diferentes contendo: i) antagomiR controle e peptídeo controle negativo (DRQIKIWFQNRRMKWKK), ii) antagomiR-21 e peptídeo controle negativo, iii) antagomiR controle e peptídeo inibidor de MyD88 (DRQIKIWFQNRRMKWKKRDVLPGT) e $i v$ ) antagomiR-21 e peptídeo inibidor de MyD88. Todas as pomadas foram preparadas imediatamente antes do tratamento utilizando vaselina como base emulsificante. Os tratamentos foram aplicados de forma a cobrir toda a área de lesão com auxílio de hastes flexíveis com algodão. Os animais foram tratados a cada $24 \mathrm{~h}$ com o antagomiR-21 / controle negativo de miRNA (100ng/g) ou a cada 48h com o peptídeo inibidor de MyD88 / peptídeo controle negativo (20ng/g) durante os 9 dias de infecção.

\subsection{In vivo imaging (IVIS)}

Para a determinação da bioluminescência emitida pela bactéria, os animais foram anestesiados com isoflurano inalatório e escaneados longitudinalmente por no máximo 4 minutos de exposição utilizando o equipamento IVIS Spectrum/CT (Perkin Elmer). A área de lesão foi determinada e desenhada de forma individual para cada animal. Uma vez delimitada a área de análise, nós avaliamos o fluxo de fótons por segundo em cada lesão descontando a interferência emitida pelo equipamento (background). O fluxo total de bioluminescência foi avaliado para cada lesão de forma independente utilizando o software Living Image ${ }^{\circledR}$.

\subsection{Ensaio de luciferase}

Os macrófagos RAW 264.7 de linhagem ( $1 \times 10^{6}$ células/poço) foram transfectados utilizando lipofectamina siRNA (diluição 1:1000) (Invitrogen) em meio Opti-MEM $^{\mathrm{TM}}$ (ThermoFisher Scientific) com $0.1 \mu \mathrm{g}$ por poço de Myd88-3'UTR luciferase ou plasmídeo vetor vazio contendo apenas luciferase. Em seguida, os macrófagos foram transfectados com $30 \mathrm{nM}$ miR-21 mimic ou miR mimic controle. Após 24h, as 
células foram lisadas e a atividade da luciferase foi avaliada. Cada amostra foi avaliada em triplicata experimental.

\subsection{Análises estatísticas}

Os resultados foram apresentados como a média \pm SEM e analisados utilizando o software GraphPad Prism 8.0 (GraphPad Software, San Diego, CA). Para comparações entre 2 grupos experimentais foi utilizado o teste $t$ Student. Para comparações entre três ou mais grupos, utilizamos one-way ANOVA ou two-way ANOVA seguido da comparação múltipla por Turkey. $\mathrm{P}<0.05$ foi considerado significativo. 


\section{RESULTADOS}

\section{1. miR-21 é expresso durante a infecção de pele por $S$. aureus}

Embora trabalhos demonstrem que a infecção tanto in vitro de BMDM por Listeria monocytogenes (221) e Mycobacterium tuberculosis (222) quanto in vivo por Mycobacterium leprae (223) está relacionada com o aumento da expressão de miR-21, poucos estudos demonstram se esse miRNA está envolvido na defesa do hospedeiro durante a infecção de pele causadas por $S$. aureus. Dessa forma, nós avaliamos, in vivo, se a infecção de pele por MRSA resulta na expressão de miR-21 em diferentes períodos de infecção. Foi observado um aumento da expressão de Mir21 nos estágios iniciais da infecção (12h), seguido de um pico de expressão em $24 \mathrm{~h}$, e subsequente declínio na expressão de Mir21 após 48h de infecção (Figura 28 A).

Os macrófagos residentes do tecido juntamente com monócitos e neutrófilos recrutados para o foco infeccioso são as principais células imunes envolvidas nas respostas contra o $S$. aureus (182). Dessa forma, nós avaliamos a contribuição tanto de macrófagos residentes como de neutrófilos na a expressão de miR21 na pele de animais infectados. Para isso, animais MMDTR foram submetidos ao tratamento subcutâneo com toxina diftérica (DT), resultando na deleção de macrófagos residentes antes do estabelecimento da infecção. A depleção de macrófagos resulta em uma tendência à diminuição da expressão Mir21 nas biópsias coletadas após 24h de infecção quando comparado aos animais que não receberam o tratamento com DT (Figura $28 \mathrm{~B}$ ). O bloqueio do recrutamento de neutrófilos utilizando anticorpos bloqueadores anti-Ly6G não interferiu na expressão global de Mir21 (Figura $28 \mathrm{C}$ ). Assim, esses resultados demonstram que os macrófagos são as células imunes responsáveis pela expressão do microRNA-21 após a infecção por MRSA na pele. 
Figura 28. Macrófagos expressam miR-21 durante a infecção de pele por $S$. aureus.

A)

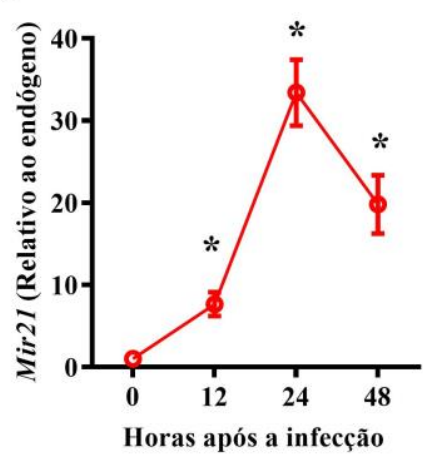

B)

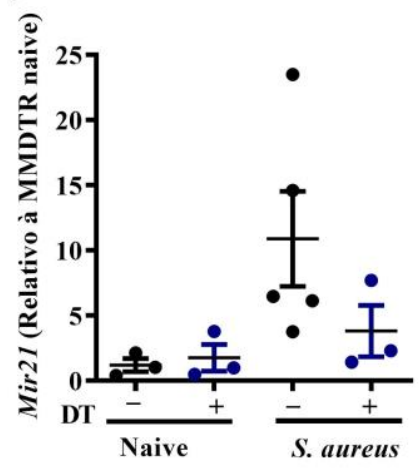

C)

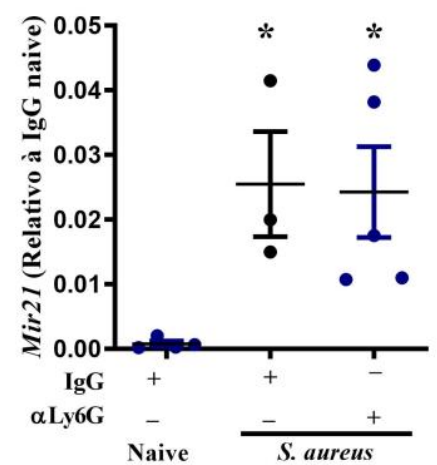

Animais foram infectados com $5 \times 10^{6}$ UFC de MRSA em $50 \mu \mathrm{L}$ de PBS e a expressão de Mir21 foi avaliada nas biópsias de pele. A) Biópsia da pele de animais selvagens analisadas em diferentes tempos. ${ }^{*} \mathrm{p}<0,05$ vs $\mathrm{t}=0$. B) Animais MMDTR foram tratados com $100 \mathrm{ng}$ de DT 1 vez ao dia durante 3 dias, e no quarto dia, os animais foram infectados. Após 24h, as biópsias foram coletadas e analisadas para a expressão de Mir21. Animais MMDTR não submetidos ao tratamento com DT foram utilizados como controle. C) Animais selvagens foram tratados com anticorpo bloqueador anti-Ly6G e, após 18h, estes foram infectados. As biópsias foram coletadas após $24 \mathrm{~h}$ de infecção e analisadas para a expressão de Mir21. O grupo controle foi tratado com um anticorpo IgG controle Resultados referentes a 2 experimentos realizados individualmente com pelo menos 3 animais por grupo. ${ }^{*} \mathrm{p}<0,05$ vs naive. 


\subsection{A expressão de miR-21 prejudica a resposta imune do hospedeiro contra $S$.}

aureus

Diferentes miRNAs estão envolvidos nas respostas de fagocitose e eliminação de patógenos, bem como durante a promoção da cicatrização de feridas, processos essenciais no controle das infecções $(205,224)$. Para avaliar se miR-21 influenciaria a resposta do hospedeiro contra $S$. aureus nós utilizamos animais deficientes em miR21 em células mielóides $\left(\operatorname{miR} 21^{\Delta \mathrm{myel}}\right)$. A escolha desse animal como modelo experimental está relacionada com os resultados que demonstraram que os macrófagos são células imunes responsáveis pela expressão de miR-21 durante a infecção de pele por MRSA (Figura 28 B). Assim, animais selvagens (WT) ou miR2 $1^{\Delta \text { myel }}$ foram infectados com MRSA e os mediadores produzidos na área da infecção bem como o tamanho do abscesso foram avaliados em diferentes momentos. Durante todo o curso da infecção, os animais miR $21^{\Delta \text { myel }}$ apresentaram lesões menores quando comparado aos animais WT (Figura 29 A e B).

A carga bacteriana presente nas lesões de WT ou miR $21^{\Delta \text { myel }}$ foi avaliada utilizando duas estratégias diferentes - contagem de UFC e a intensidade de emissão de bioluminescência. Animais miR2 $1^{\Delta \text { myel }}$ apresentam um menor número de UFC nas lesões 1 dia após a infecção quando comparado à quantidade de UFC presente nas lesões oriundas de animais WT (Figura 29 C).

Esses dados foram confirmados através da quantificação da bioluminescência emitida pelas bactérias presentes nas lesões utilizando o equipamento IVIS Spectrum/CT, que avalia a quantidade de fótons por segundos emitidos pela MRSA bioluminescente presentes nas lesões de pele dos animais. As análises das lesões de pele de animais miR21 $1^{\Delta \text { myel }}$ demonstraram uma menor intensidade de emissão de bioluminescência nos dias 1, 3, 6 e 9 após a infecção quando comparada com a intensidade de bioluminescência emitida pelas bactérias presentes nas lesões de WT nos mesmos tempos (Figura 29 D).

O reconhecimento do $S$. aureus pelas diferentes células residentes do tecido e células imunes induz a produção de diversas citocinas relacionadas com a patogênese da infecção. Dessa forma, avaliamos a influência de miR-21 na produção desses mediadores durante a infecção por MRSA. Os animais miR2 $1^{\Delta \text { myel }}$ apresentam níveis 
elevados de citocinas inflamatórias, como IL-1 $\beta$ e TNF- $\alpha$, e diminuição da produção de IL-6 e IL-1 $\alpha$ nos tecidos oriundos das biópsias 1 dia após a infecção quando comparado às biópsias oriundas de animais WT. Interessantemente, nós também detectamos um aumento nos níveis de IL-10 na pele dos animais miR2 $1^{\Delta \text { myel }}$ quando comparado à pele de animais WT (Figura 29 E-I). Através do ensaio de Luminex® nós detectamos também um aumento de p-selectina e TNFRI nas biópsias de animais miR21 $1^{\Delta \text { myel }}$ quando comparado as biópsias de animais WT (dados não mostrados). 
Figura 29. A inibição de miR-21 melhora a defesa do hospedeiro durante a infecção de pele por $S$. aureus

A)

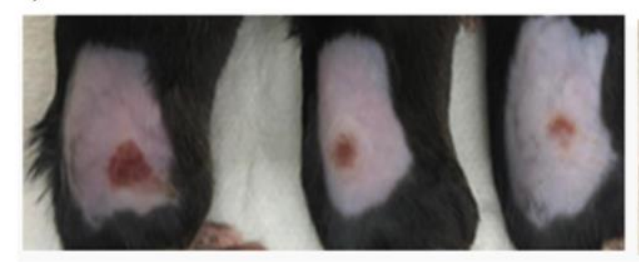

B)

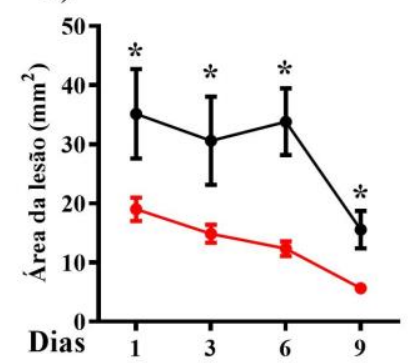

E)

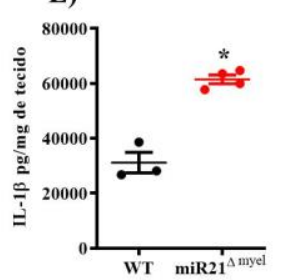

F)

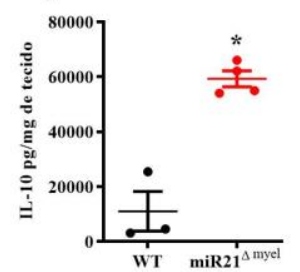

C)

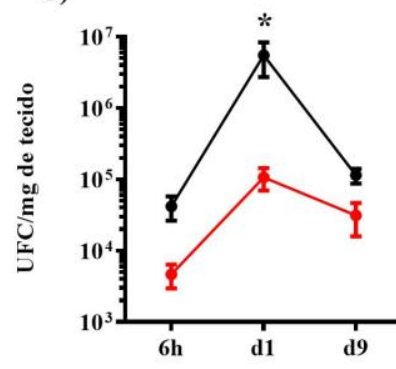

G)
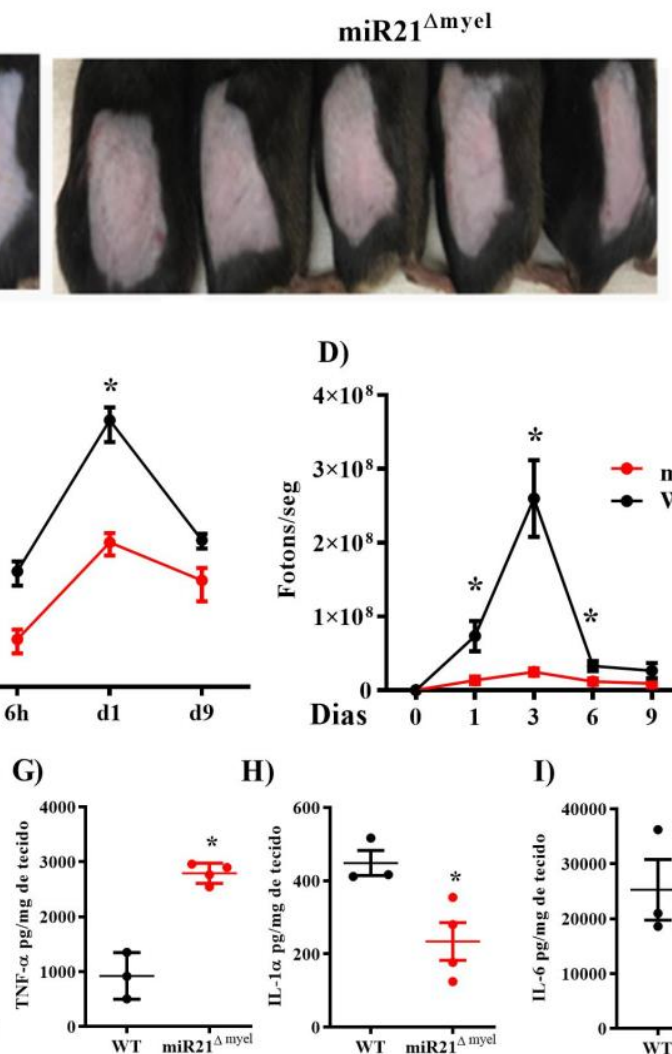

D)

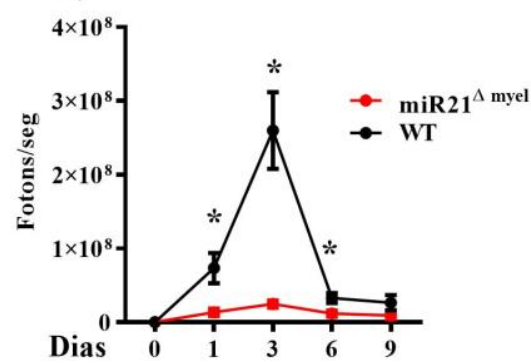

H)

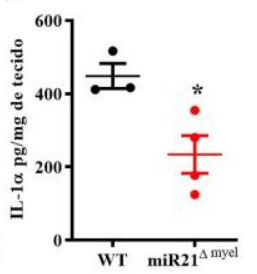

I)

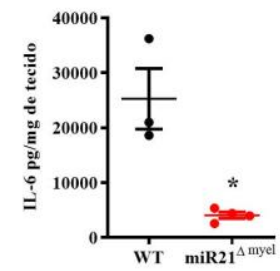

Animais C57BL/6 selvagens (WT) ou miR2 $1^{\text {smyel }}$ foram infectados subcutaneamente com $5 \times 10^{6}$ UFC de MRSA em 50uL de PBS. A) Animais dos dois grupos experimentais foram fotografados após $24 \mathrm{~h}$ de infecção. B) A área de infecção foi medida diariamente durante os nove dias de infecção. C) A quantidade de UFC foi avaliada através do plaqueamento, em TSA, do homogenato das lesões, nos tempos de 6h, 1 e 9 dias após a infecção. D) Quantificação diária da bioluminescência emitida pelas bactérias presentes nas lesões durante todo o curso da infecção. Resultados expressos em Fotons/segundos. E-I) Quantificação das citocinas presentes nas biópsias de pele coletadas após $24 \mathrm{~h}$ de infecção por Luminex® (IL-1 $\alpha$ e IL-1 $\beta$ ) e ELISA (IL-10, IL-6 e TNF- $\alpha$ ). Resultados referentes a 3 experimentos realizados individualmente com 5 animais por grupo experimental. $* \mathrm{p}<0,05 \mathrm{vs} \mathrm{WT}$. 


\subsection{A inibição de miR-21 resulta na melhora das respostas contra $S$. aureus}

Os resultados obtidos com animais miR $21^{\Delta \text { myel }}$ foram confirmados através da inibição da expressão do miR-21 utilizando antagomiR-21 após a infecção com $S$. aureus. Esse é um dado importante uma vez que abre novos horizontes para o tratamento de feridas na pele de pacientes infectados com MRSA. Dessa forma, avaliamos se o tratamento localizado com uma pomada contendo antagomiR-21 resultaria no aumento do controle da infecção de pele causada por MRSA. Para isso, animais WT foram tratados topicamente com uma pomada contendo antagomiR-21 ou antagomiR controle (scrambled), diariamente, uma vez ao dia. Os animais infectados e tratados com a pomada contendo antagomiR-21 apresentaram uma diminuição no tamanho das lesões durante todo o curso da infecção quando comparado aos animais que receberam o tratamento com controle negativo (Figura $30 \mathrm{~A} \mathrm{e} \mathrm{B}$ ).

Os animais que receberam o tratamento com o antagomiR-21 apresentaram uma menor carga bacteriana (UFC) nas lesões de pele, após 9 dias de infecção (Figura 30 C). Esses dados foram confirmamos através da avaliação da intensidade de bioluminescência emitida pelas bactérias presentes nas lesões de animais tratados ou não com o antagomiR-21 (Figura 30 D). A figura 30 E, refere-se à imagem representativa de um animal de cada grupo experimental durante o curso da infecção e sua respectiva carga bacteriana obtida a partir da quantificação da intensidade de bioluminescência emitida pelas bactérias presentes nas lesões de pele. Esses dados confirmam os resultados obtidos utilizando animais miR2 $1^{\Delta \text { myel }}$. A presença de miR-21 prejudica a eliminação bacteriana favorecendo o aumento da lesão tecidual. 
Figura 30. O tratamento cutâneo com antagomiR-21 resulta em uma eficiente eliminação bacteriana e diminuição da área de lesão durante a infecção por $S$. aureus.

A)

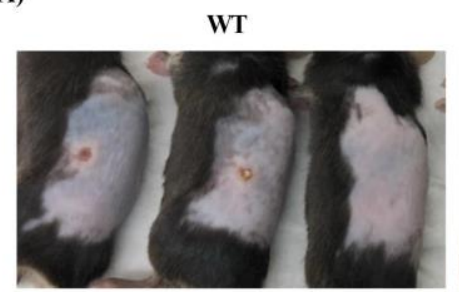

B)

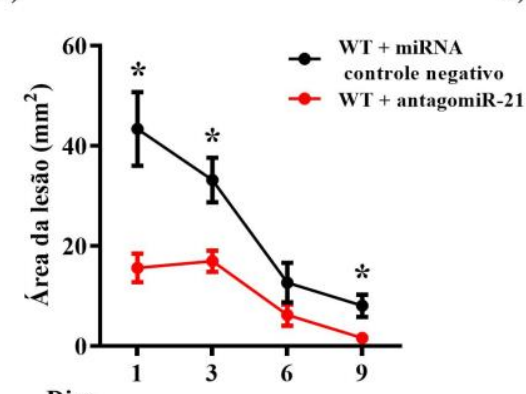

Dias

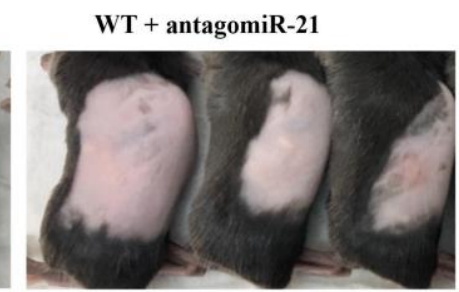

C)

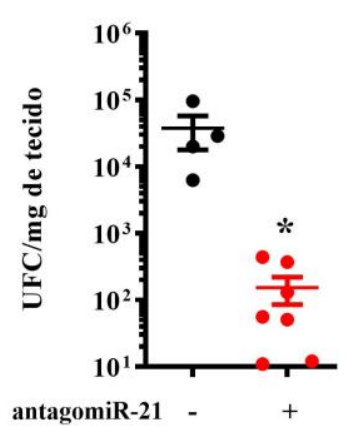

D)

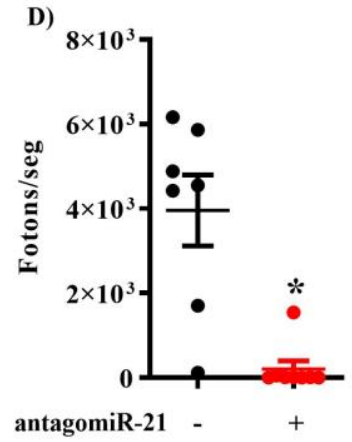

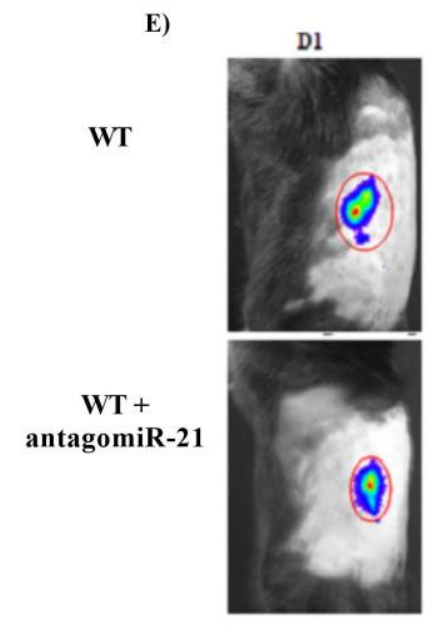
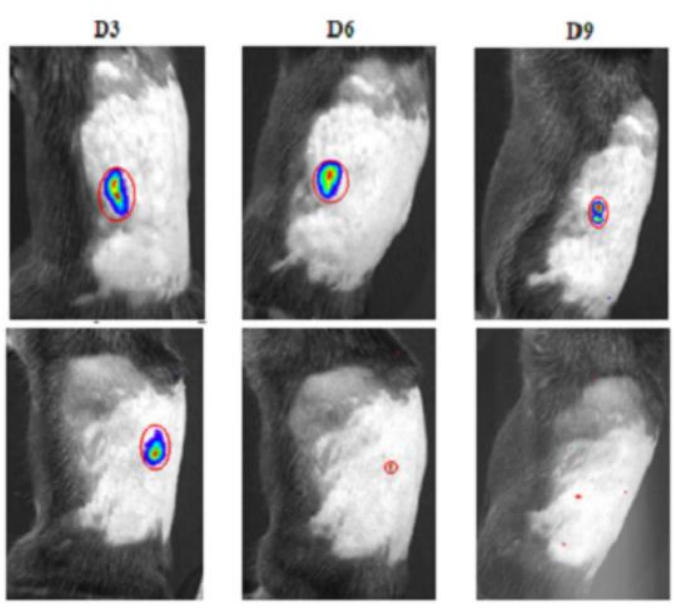

Animais WT foram infectados com $5 \times 10^{6}$ UFC de MRSA em $50 \mu \mathrm{L}$ de PBS e tratados com antagomiR-21 ou antagomiR controle (100ng/g emulsificado em $100 \%$ de vaselina), diariamente, durante todo o curso da infecção. A) Fotografia da área da lesão após $24 \mathrm{~h}$ de infecção. B) Área da lesão durante os 9 dias de infecção. C) Quantidade de UFC presente nas lesões dos animais após nove dias de infecção. D) Avaliação da quantidade de bioluminescência emitida pelas bactérias presentes nas lesões após nove dias de infecção. E) Figura representativa da bioluminescência emitida pelas bactérias presentes nas lesões de pele em diferentes dias. Resultados referentes a 2 experimentos realizados individualmente com 5 animais por grupo. * $\mathrm{p}<0,05$ vs $\mathrm{WT}+$ veículo controle. 


\subsection{A deficiência de miR-21 melhora a formação do abscesso durante a infecção} de pele por $S$. aureus

A formação do abscesso é um mecanismo do hospedeiro para conter a disseminação e auxiliar a eliminação do patógeno (182, 225). Análises imunohistopatológicas demonstram que em biópsias derivadas de animais miR21 $1^{\Delta \text { myel }}$ há um intenso acúmulo de macrófagos (células F4/80 positivas) na região de cápsula do abscesso quando comparado as biópsias oriundas de animais WT (Figura 31). O acúmulo de macrófagos foi acompanhado por um aumento na espessura da cápsula ao redor da área do abscesso em animais miR2 $1^{\Delta \text { myel }}$ quando comparado à espessura da cápsula encontrada em abscessos de WT após 24h de infecção (Figura 32 A).

Macrófagos e fibroblastos são as principais células responsáveis pela produção de colágeno durante a reparação tecidual $(226,227)$. A depleção de macrófagos no modelo de ferida estéril resulta em uma diminuição na produção de colágeno e um retardo na cicatrização da pele dos animais (228). Dessa forma, a nossa próxima etapa foi investigar se a ausência de miR-21 em células mielóides poderia alterar a produção de colágeno na pele de animais infectados com MRSA. Animais miR2 $1^{\Delta \text { myel }}$ apresentam um aumento da deposição de colágenos (coloração de tricromo de Masson) nas cápsulas que circundam os abscessos na pele dos animais após $24 \mathrm{~h}$ de infecção quando comparado as biópsias oriundas de animais WT (Figura 32 B). 
Figura 31. A deficiência de miR-21 promove acúmulo de macrófagos na borda do abscesso.
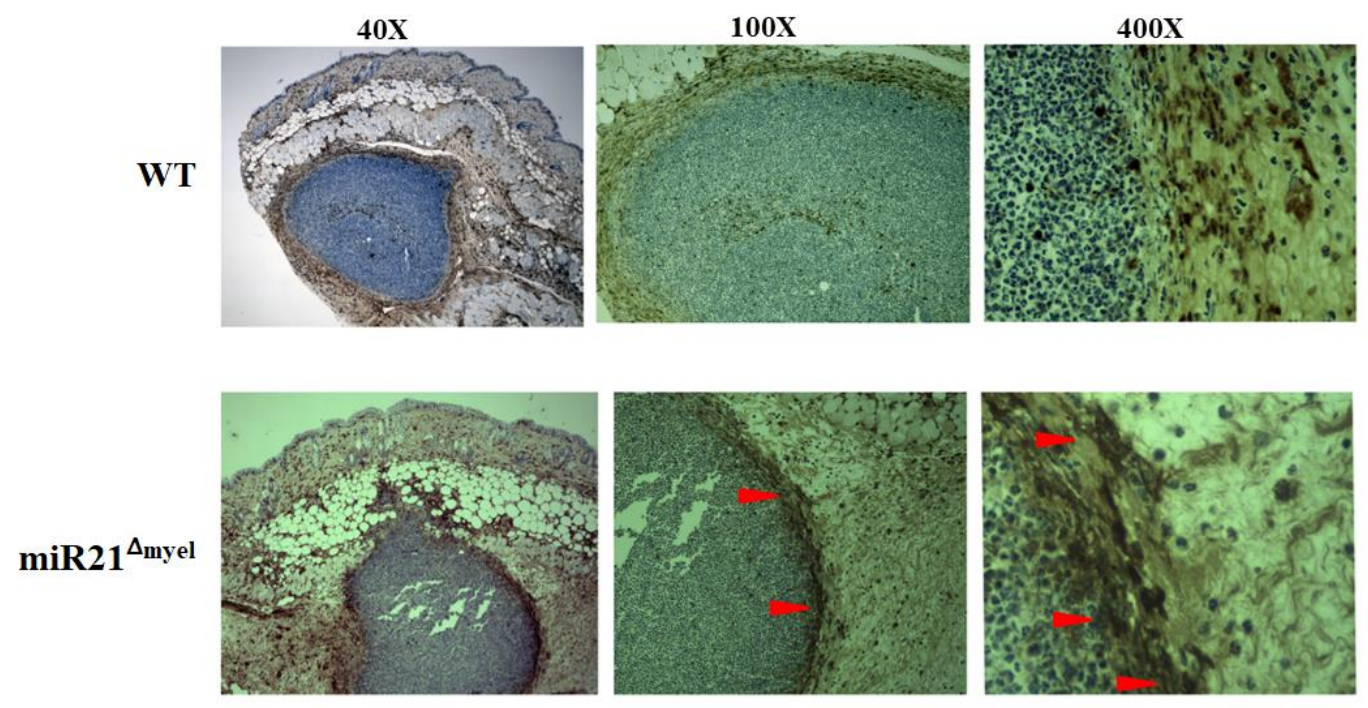

Animais selvagens (WT) e animais miR2 $21^{\text {smyel }}$ foram infectados com $5 \times 10^{6}$ UFC de MRSA em $50 \mu \mathrm{L}$ de PBS e, após 24h de infecção, as biópsias foram coletadas e marcadas utilizando anticorpo anti-F4/80. As fotografias foram adquiridas utilizando três diferentes lentes de aumento, 40, 100 e 400x. As células coradas em azul são neutrófilos corados pelo corante de hemtoxilina usado como contracoloração. 
Figura 32. A deficiência de miR-21 promove o aumento da espessura do abscesso e deposição de colágeno.

A)
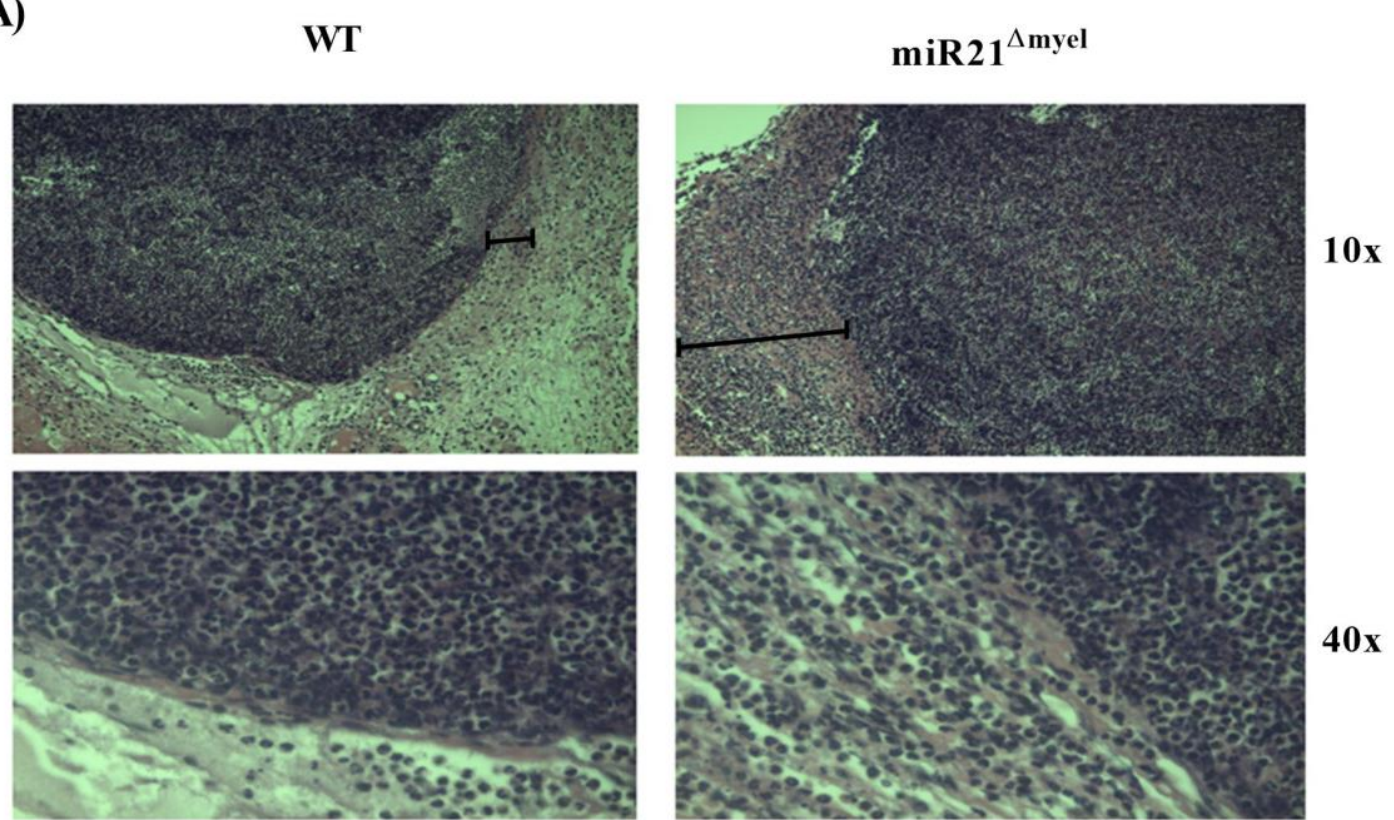

$40 x$

B) WT
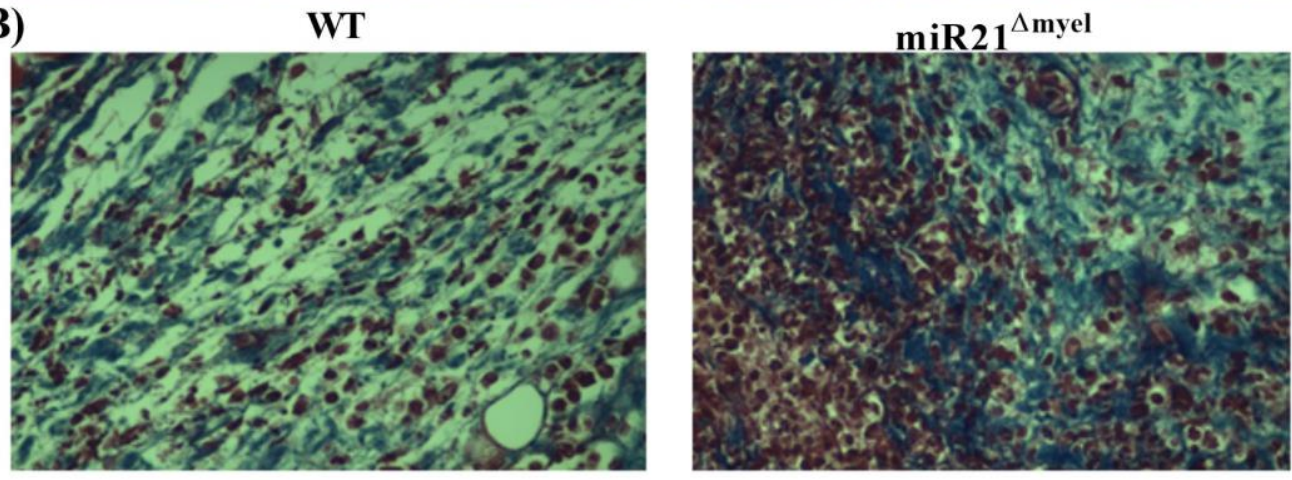

$40 x$

Animais selvagens (WT) e animais miR2 $1^{\Delta \text { myel }}$ foram infectados com $5 \times 10^{6}$ UFC de MRSA em $50 \mu \mathrm{L}$ de PBS e, após $24 \mathrm{~h}$ de infecção, as biópsias foram coletadas e analisadas para A) Marcação de hematoxilina e eosina. Fotografias adquiridas utilizando aumento de 10 e 40 vezes. B) Marcação para tricromo de Masson. Fotografias adquiridas utilizando aumento 40 vezes. 
Para determinar se o aumento da deposição de colágeno observada em animais miR2 $1^{\Delta \text { myel }}$ estava relacionada com o aumento da expressão de genes responsáveis pela produção de colágeno, bem como de uma regulação do fenótipo de macrófagos para o perfil M2, nós avaliamos a expressão de genes do colágeno e marcadores da população M2 de macrófagos nas feridas de WT e miR2 $1^{\Delta \text { myel }}$ após $24 \mathrm{~h}$ de infecção. Animais miR2 $1^{\Delta \text { myel }}$ apresentam maior expressão de Colla3 nos tecidos $24 \mathrm{~h}$ após a infecção quando comparado a expressão desses genes nos tecidos oriundos de animais WT infectados (Figura 33 A). A expressão de Collal e Colla2 também foi avaliada, entretanto, não detectamos diferenças na expressão desses genes nas biópsias de pele de animais WT e miR21 $1^{\Delta \text { myel }}$ (dados não mostrados).

Nós observamos também um aumento da expressão de genes relacionados ao perfil M2 de macrófagos como Chil3ll e Cd36 (229-231) em animais miR21 $1^{\Delta \text { myel }}$ quando comparado a expressão desses marcadores nas biópsias de animais WT (Figura 33 B e C). Interessantemente, a análise dos mesmos genes nas biópsias de animais WT tratados, ou não, com a pomada contendo antagomiR-21, revelou o mesmo padrão de resposta encontrado em animais miR2 $1^{\Delta \mathrm{myel}}$. Animais tratados com antagomiR-21 apresentam um aumento na expressão de Colla3, Chi3l1 e Cd36 nos tecidos após 9 dias de infecção quando comparado aos tecidos infectados de animais que foram tratados com o antagomiR controle (Figura 33 D-F). 
Figura 33. A infecção por $S$. aureus induz um perfil gênico semelhante em animais miR21 $^{\Delta \text { myel }}$ e animais tratados com antagomir-21.

A)

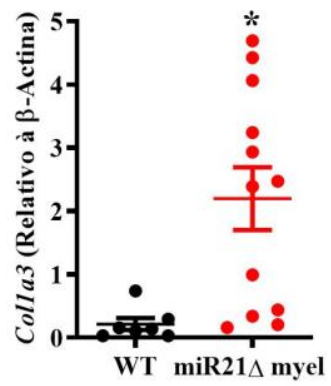

D)

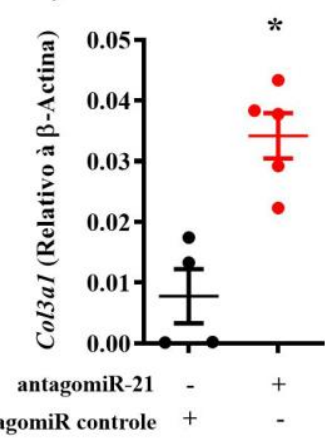

B)

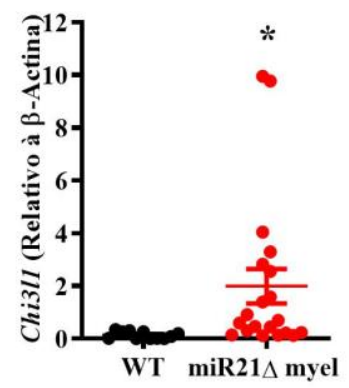

E)

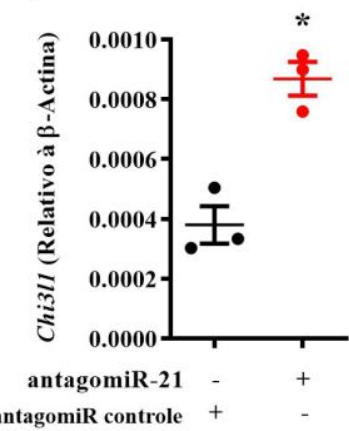

C)

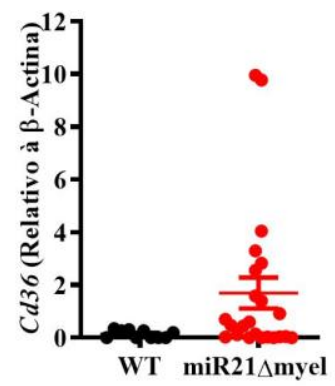

F)

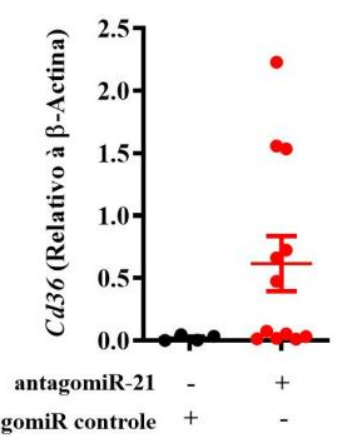

Animais WT e animais miR2 $21^{\Delta \text { myel }}$ foram infectados com $5 \times 10^{6}$ UFC de MRSA em $50 \mu \mathrm{L}$ de PBS e, após $24 \mathrm{~h}$ de infecção, as biópsias foram coletadas e a expressão dos seguintes genes foram analisadas por qPCR. A) Colla3. B) Chi3ll. C) Cd36. Animais WT foram infectados com $5 \times 10^{6}$ UFC de MRSA em $50 \mu \mathrm{L}$ de PBS e tratados com antagomiR-21 ou antagomiR controle (100ng/g emulsificado em $100 \%$ de vaselina), diariamente, durante todo o curso da infecção. Após 9 dias, as biópsias foram coletadas e a expressão dos seguintes genes foi avaliada por qPCR. D) Colla3. E) Chi3ll. F) Cd36. Resultados referentes 2 experimentos realizados individualmente como pelo menos 3 animais por grupo. ${ }^{*} \mathrm{p}<0,05$ vs WT e \# $\mathrm{p}<0,05$ vs WT +antagomiR controle. 


\section{5 miR-21 inibe a resolução da infecção por $S$. aureus cutânea via de MyD88}

MyD88 é uma proteína adaptadora que contribui para a defesa do hospedeiro contra $S$. aureus, uma vez que essa molécula é essencial tanto para a sinalização de receptores do tipo toll $(215,232)$ quanto receptores de citocinas, como IL-1 $\beta$, IL-1 $\alpha$, IL33, produzidas durante as respostas a essa bactéria (216). Animais deficientes para MyD88 são mais susceptíveis a infecção por S. aureus (217) uma vez que apresentam maior carga bacteriana nas lesões bem como uma menor migração de neutrófilos para o tecido infectado (218). Dessa forma, nós avaliamos se miR-21 poderia regular negativamente a expressão de $M y d 88$ durante a infecção por $S$. aureus. Animais miR2 $2{ }^{\Delta \text { myel }}$ apresentam uma tendência ao aumento da expressão de $M y d 88$ na pele 24h após a infecção quando comparado à expressão dessa molécula da pele de animais WT (Figura 34 A). Além disso, macrófagos da linhagem RAW264.7 foram transfectados com um plasmídeo expressando Myd88-3`UTR e luciferase ou plasmídeo vetor vazio contendo apenas luciferase, seguida da transfecção com miR-21 mimic ou miR mimic controle. Macrófagos transfectados com plasmídeo expressando Myd88-3'UTR luciferase e miR-21 mimic apresentam uma inibição da bioluminescência emitida quando comparado aos macrófagos transfectados com o plasmídeo expressando Myd883’UTR luciferase e o miR mimic controle, demonstrando que miR-21 é capaz de inibir a expressão de Myd88 (Figura 34 B).

Para confirmamos que miR-21 atua inibindo a via de sinalização de MyD88 durante a infecção de pele por MRSA, nós infectamos animais WT e os submetemos a 4 diferentes tratamentos: i) pomada contendo antagomiR controle e peptídeo controle negativo, ii) pomada contendo antagomiR-21 e peptídeo controle negativo, iii) pomada contendo antagomiR controle e peptídeo inibidor de MyD88 e iv) pomada contendo antagomiR-21 e peptídeo inibidor de MyD88. O tratamento com antagomir-21 e peptídeo controle negativo resulta na formação de lesões com menor área de extensão na pele desses animais (linha vermelha) quando comparado ao grupo de animais que receberam a pomada contendo antagomiR controle e peptídeo controle negativo (linha preta) (Figura 34C).

Corroborando aos dados da literatura que demonstram que a infecção por $S$. aureus induz maiores lesões de pele em animais deficientes de MyD88 quando 
comparado a animais WT (218), animais infectados e tratado com a pomada contendo antagomiR controle e peptídeo inibidor de MyD88 (linha azul) apresentam lesões de pele maiores que animais tratados com os controles negativos, linha preta, ou tratados apenas com o antagomiR-21, linha vermelha (Figura 34C). Por fim, animais tratados com antagomiR-21 e peptídeo inibidor de MyD88 apresentam as maiores áreas de lesão na pele quando comparado aos outros três grupos experimentais (linha verde). Esses dados sugerem que miR-21 atua inibindo a via de sinalização de MyD88 prejudicando o controle da infecção de pele causada por S. aureus. 
Figura 34. miR-21 inibe MyD88 durante a infecção por S. aureus.

A)

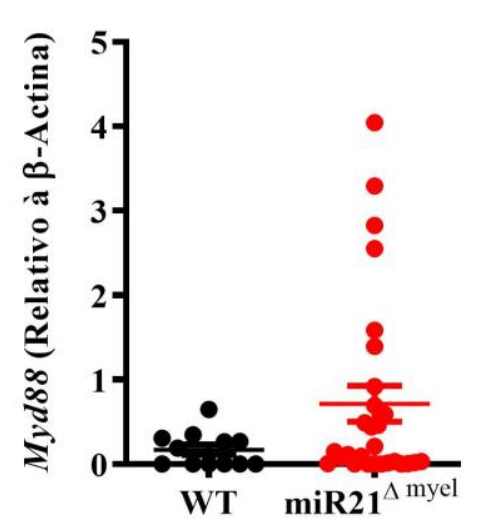

C)
B)

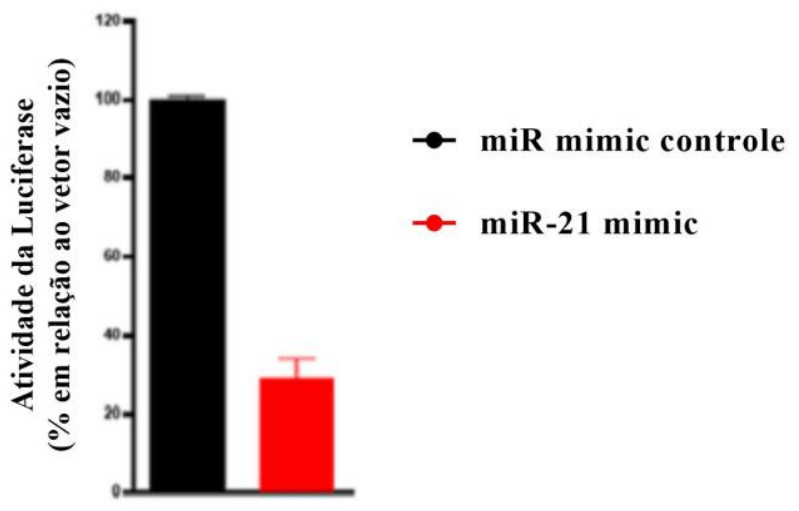

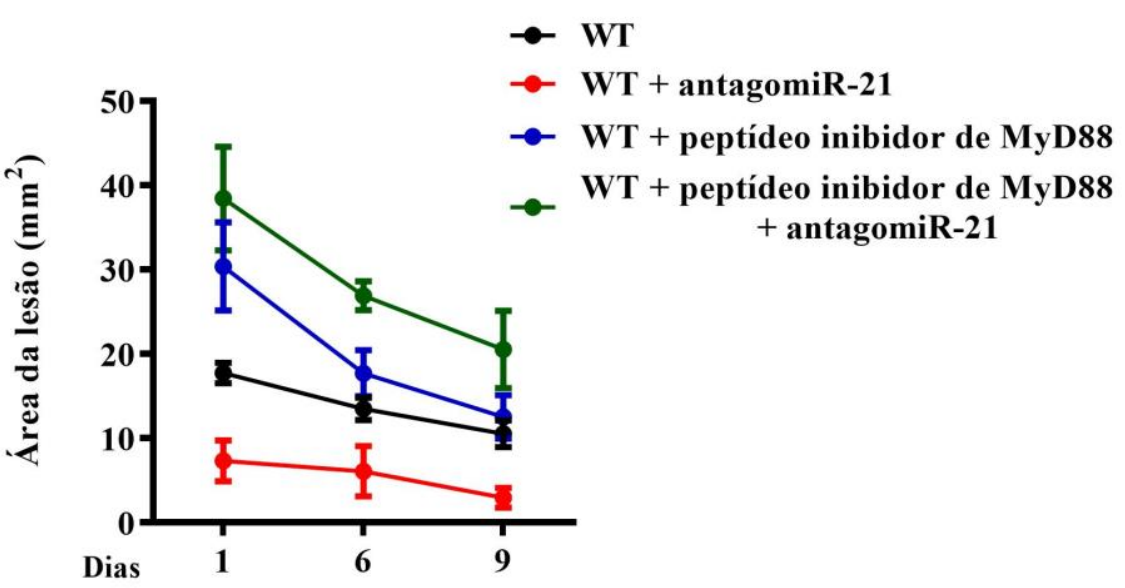

A) Animais WT e miR2 $1^{\Delta \text { myel }}$ foram infectados com $5 \times 10^{6}$ UFC de MRSA em $50 \mu \mathrm{L}$ de PBS e, após $24 \mathrm{~h}$ de infecção, as biópsias foram coletadas e analisadas para a expressão de Myd88 por RT-qPCR. Resultado referente a 3 experimentos realizados individualmente. B) Macrófagos da linhagem RAW 264.7 foram transfectados com plasmídeo expressando Myd88-3`UTR luciferase ou plasmídeo vetor vazio contendo apenas luciferase. Em seguida, os macrófagos também foram transfectados com miR-21 mimic ou miR mimic controle por 24h. Após esse período as células foram lisadas e a atividade da luciferase foi avaliada. Resultado de um experimento realizado em triplicata experimental. C) Animais WT foram infectados com $5 \times 10^{6}$ UFC de MRSA em $50 \mu \mathrm{L}$ de PBS e tratados como 4 diferentes pomadas: $i$ ) pomada contendo antagomiR controle e peptídeo controle negativo, ii) pomada contendo antagomiR-21 e peptídeo controle negativo, iii) pomada contendo antagomiR controle e peptídeo inibidor de MyD88 e iv) pomada contendo antagomiR-21 e peptídeo inibidor de MyD88. O tamanho da lesão foi avaliado nos dias 1, 6 e 9 após a infecção. Resultado de 1 experimento com 5 animais por grupo experimental. 


\section{DISCUSSÃO}

O reconhecimento inicial de um microrganismo invasor ocorre tanto por células do tecido quanto por células imunes residentes desencadeando a produção de mediadores inflamatórios que induzem a migração de monócitos e neutrófilos para o foco infeccioso colaborando para a eliminação do patógeno. Com o declínio da carga bacteriana e, consequentemente, da infecção, as células imunes passam a apresentar um fenótipo mais resolutivo com a produção de mediadores anti-inflamatórios, eliminação de células mortas e promoção da remodelação tecidual de modo que o tecido afetado retorne à condição basal anterior a infecção. Todas as etapas desde o início da infecção até o retorno à homeostasia tecidual podem ser controladas por microRNAs.

A expressão dos mais diversos miRNAs é descrita durante a infecção por $S$. aureu. Jingjing e colaboradores demonstraram que a infecção por $S$. aureus resulta em uma diminuição da expressão de miR-24 em macrófagos murinos e humanos favorecendo a diferenciação dessa células a um perfil M1 de ativação celular (203). Monócitos bovinos incubados com $S$. aureus apresentam uma diminuição na expressão de miRNAs inflamatórios como miR-155 e miR-125b (233). Animais deficiente para o microRNA-223 e infectados com $S$. aureus apresentam uma maior carga bacteriana nas lesões de pele associada à maiores abscessos (207). Além disso, animais deficientes de miR-142 possuem uma menor taxa de fagocitose de $S$. aureus bem como uma migração anormal de neutrófilos durante as respostas à infecção de pele causada por essa bactéria (205). Células epiteliais das glândulas mamárias quando infectadas com S. aureus apresentam um aumento da expressão de miR-21 em 12h de infecção (234). Porém, até o momento, nada se tem descrito correlacionando a presença de miR-21 com infecções de pele causadas por MRSA.

Nós observamos que, durante a infecção de pele causada por S. aureus, ocorre um aumento da expressão de Mir21 nas primeiras 24h após a infecção. Kerckhove e colaboradores correlacionam a expressão de miR-21 com a cicatrização de feridas na pele de animais por si só, uma vez que foi observado um aumento da expressão de diversos miRNAs, entre eles o miR-21, em lesões estéreis (207). Novos experimentos são necessários para determinar se gatilho para o aumento da expressão de miR-21 em 
nosso modelo foi: $i$ ) a presença da bactéria, ii) a formação da ferida na pele dos animais ou, ainda, iii) a somatória das respostas desencadeada pela presença da bactéria e a formação do abscesso que é a hipótese em que acreditamos. Os experimentos prévios que demonstraram aumento da expressão de miR-21 frente a infecção por S. aureus foram realizados in vitro, e, portanto, sem a formação de lesões teciduais (234). Além disso, infecções por outros patógenos como Listeria monocytogenes (221), Mycobacterium tuberculosis (222) e Mycobacterium leprae (223) estão relacionadas ao aumento da expressão de miR-21, tanto in vitro como in vivo.

A expressão de miR-21 está associada a modulação de diferentes processos fisiológicos, como proliferação e apoptose celular, inflamação, angiogênese e respostas às infecções bacterianas $(235,236)$. Dessa forma, avaliamos se a presença de miR-21 poderia modular as respostas imunes do hospedeiro contra S. aureus. Para isso, nós utilizamos animais que não expressam miR-21 em células mielóides, uma vez que foi detectada a importância dos macrófagos para a expressão de miR-21 em nosso modelo experimental. A ausência de miR-21 se mostrou benéfica para o controle à infecção de pele por $S$. aureus, uma vez que os animais miR $21^{\Delta \mathrm{myel}}$ apresentaram menores lesões quando comparado as lesões apresentadas por animais WT.

O tamanho do abscesso (lesão) está relacionado diretamente com a quantidade de infiltrado celular, bactérias presentes no tecido afetado e necrose tecidual. Nós observamos que animais $\operatorname{miR} 21^{\Delta \text { myel }}$ apresentaram uma menor carga bacteriana no decorrer de toda a infecção nos abscessos de pele sugerindo que na ausência de miR-21 ocorre uma melhor eliminação do patógeno. Corroborando aos nossos achados, há relatos demonstrando que o aumento da expressão de miR-21 durante infecções por Mycobacterium leprae (223), Leishmania infantum (237), Brucella spp (238) e vírus da hepatite C (239) prejudica a eliminação desses patógenos.

A melhora na resolução da infecção bacteriana pode estar relacionada a diferentes fatores como: um aumento da capacidade fagocítica, aumento na produção de citocinas que podem atuar promovendo a ativação de novas células imunes, produção de reativos de oxigênio e nitrogênio que favoreceriam a eliminação do patógeno e aumento da eferocitose de células mortas evitando a liberação de DAMPs no tecido. Macrófagos dermais transfectados com miR-21 mimic não apresentaram maior taxa de fagocitose de 
S. aureus in vitro quando comparado a células transfectadas com miR mimic controle (dados não mostrados).

As biópsias da pele de animais miR2 $1^{\Delta \text { myel }}$ infectados com $S$ aureus apresentam níveis elevados das citocinas IL-1 $\beta$ e TNF- $\alpha$ bem como de IL-10 quando comparado as biópsias oriundas de animais WT. Estudos prévios demonstraram que tanto TNF- $\alpha$ como IL-1 $\beta$ possuem um papel chave no controle da infecção por S. aureus $(216,218$, 240, 241). A produção de TNF- $\alpha$ por queratinócitos, mastócitos e macrófagos dermais favorecem a eliminação do $S$. aureus $(241,242)$. Recentes dados obtidos por nosso grupo de pesquisa demonstraram que a IL-1 $\beta$ produzida durante a infecção por MRSA é imprescindível para o controle da carga bacteriana na pele dos animais infectados (artigo em fase de revisão). Além disso, animais deficientes para o receptor de IL-1 (IL1R) apresentam acúmulo de $S$. aureus e maior dano no tecido ósseo em caso de osteomielite causada por esse patógeno (216). Miller e colaboradores demonstraram que a IL-1 $\beta$ produzida durante a infecção por $S$. aureus dirige o recrutamento de neutrófilos e a defesa do hospedeiro contra a infecção (240). Dessa forma, o aumento de IL-1 $\beta$ e TNF- $\alpha$ na pele de animais miR $21^{\Delta \text { myel }}$ pode estar favorecendo o controle microbiano em nosso modelo experimental.

Nós também detectamos um aumento da produção de IL-10 na pele de animais miR2 $1^{\Delta \text { myel }}$ após a infecção. A literatura existente apresenta divergências quanto ao papel da IL-10 durante a infecção por S. aureus. Stenzel e colaboradores demonstraram que animais deficiente de IL-10 apresentam um aumento da suscetibilidade a $S$. aureus associada à vasculite necrotizante, hemorragia e, consequentemente, desenvolvimento de edema no modelo de abscesso cerebral (243). Nesse mesmo estudo, os autores demonstraram que o excesso de inflamação observado somado ao recrutamento descontrolado de leucócitos não foram associados à melhora da eliminação do patógeno, sugerindo que esse microambiente pode favorecer o recrutamento de células incapazes de desempenhar suas funções efetoras $(243,244)$. Por outro lado, Rose e colaboradores observaram que pacientes que apresentam elevados níveis de IL-10 na corrente sanguínea em decorrência de bacteremia causada por S. aureus apresentam maior índice de mortalidade (245). Leech e colaboradores sugerem que o papel da IL-10 produzida durante a infecção é depende do tecido onde está atuando. Os autores demonstram que a 
IL-10 produzida durante a infecção sistêmica protege o hospedeiro por controlar as respostas pró-inflamatórias e, dessa forma, prevenir a inflamação excessiva. Por outro lado, os mesmos autores sugerem que a IL-10 facilita a persistência bacteriana durante a infecção subcutânea aguda. Animais deficientes de IL-10 exibiram menores lesões e reduzida carga bacteriana após a infecção por $S$. aureus quando comparado a animais WT (246). Assim, novos experimentos são necessários para determinar se a IL-10 produzida durante a infecção em nosso modelo experimental favorece ou não o controle da infecção causada por S. aureus. Ao que tudo indica a presença de IL-10 em nosso modelo é capaz de equilibrar o microambiente inflamatório evitando a inflamação excessiva e promovendo uma melhora nas respostas do hospedeiro uma vez que também observamos uma diminuição na liberação de IL-1 $\alpha$ nas biópsias oriundas de animais $\operatorname{miR} 21^{\Delta \text { myel }}$.

A maioria das infeções de pele são causadas por S. aureus e MRSA. Esses quadros se iniciam como furúnculos ou abscessos pequenos que podem progredir para infecções graves envolvendo músculos, órgãos, válvulas cardíacas e ossos (247). Dessa forma, a busca por novas estratégias que visam o controle e eliminação dessa bactéria são imprescindíveis para a melhora da qualidade de vida dos pacientes. Nossos resultados demonstram que o tratamento tópico com o antagomiR-21 induziu um perfil de resposta semelhante ao apresentado por animais $\mathrm{miR} 21^{\Delta \mathrm{myel}}$. Animais tratados com antagomiR-21 apresentaram um quadro mais brando de infecção com lesões mais circunscritas e uma menor carga bacteriana. Nossos resultados demonstram pela primeira vez a eficiência da adição exógena dessa molécula como opção de tratamento de feridas de pele causadas por MRSA. Experimentos adicionais são indispensáveis para validar a eficiência do tratamento tópico utilizando o antagomiR-21 em modelos de infecção já estabelecida como o que ocorre quando os pacientes são tratados. Além disso, é importante determinar se o tratamento tópico com essa molécula é capaz que interferir nos níveis sistêmicos de miR-21, o tempo de meia vida do antagomiR, a posologia necessária para um tratamento eficaz, possíveis efeitos colaterais in sito ou em órgãos distantes e interação com comorbidades.

Além disso, em nosso trabalho, o tratamento de animais WT com a molécula de antagomiR é uma contraprova de que os efeitos observados em animais miR2 $21^{\Delta \text { myel }}$ são 
decorrentes da ausência de miR-21 e não de outras alterações que o animal deficiente dessa molécula possa apresentar.

A formação do abscesso é uma resposta do hospedeiro frente à infecção por $S$. aureus que tem um papel importante tanto na contenção da infecção no local da ferida impedindo a dispersão bacteriana a outros tecidos através da deposição de fibrina e colágeno na borda do abscesso (185), quanto pelo acúmulo de neutrófilos no foco infeccioso que colaboram para o controle microbiano $(182,225)$. A depleção de macrófagos no modelo de ferida estéril resulta em uma diminuição na produção de colágeno e um retardo na cicatrização da pele dos animais (228). Nossos resultados demonstram que animais $\operatorname{miR} 21^{\Delta \text { myel }}$ infectados com $S$. aureus apresentam um espessamento na borda dos abscessos bem como um acúmulo de macrófagos na região da cápsula do abscesso quando comparado aos abscessos de animais WT. Macrófagos são as principais células imunes responsáveis pela eferocitose de células mortas (76). Dessa forma, o acúmulo de macrófagos na região de cápsula do abscesso reforça a hipótese de que na pele de animais miR2 $1^{\Delta \text { myel }}$ ocorre uma maior eferocitose, evitando a liberação de DAMPs e, portanto, favorecendo uma melhor resolução da infecção. Experimentos adicionais são necessários para comprova se existe um aumento da eferocitose e promoção do reparo tecidual nos abscessos de animais miR $21^{\Delta \text { myel }}$.

A interação de macrófagos com sinais find-me liberadas durante o processo de morte celular desencadeia a polarização dessas células para um perfil M2 com aumento Arginase-1, IL-4, IL-10 (72), Fizz1, CD206 (122) e PGE 2 , fator de crescimento endotelial vascular e inibição de NF- $\mathrm{B}$ associada à diminuição de citocinas inflamatórias como TNF- $\alpha$, IL-12, CXCL1 e CXCL2 (7, 28, 73-76). Animais miR2 $21^{\Delta \text { myel }}$ infectados com $S$. aureus apresentam um aumento da expressão de genes relacionados ao perfil M2 de macrófagos nas biópsias de pele quando comparado as biópsias de animais WT. Corroborando aos nossos dados, Aldrich e Kielian demonstraram que durante a infecção por $S$. aureus ocorre um acúmulo de macrófagos M2 na parede de abscessos cerebrais (190).

Muitos trabalhos demonstram que macrófagos M2 são células que apresentam alta capacidade de proliferação, remodelação tecidual e cicatrização de lesões devido ao metabolismo da arginase que é associado à produção de colágeno e matriz extracelular 
(76, 194-197). Nesse trabalho, nós detectamos aumento da expressão de Colla3 bem como uma maior deposição de colágeno na borda do abscesso formado na pele de animais miR2 $1^{\Delta \text { myel }}$ quando comparado a deposição de colágeno na borda de abscesso de animais WT. Entretanto, contrário aos nossos resultados, diversos estudos relacionam o aumento da deposição de colágeno e fibrose tecidual com um aumento da expressão de miR-21 (248-251). Assim, novos experimentos são necessários para demonstrarmos os mecanismos pelos quais o aumento da expressão e deposição de colágeno em animais miR $21^{\Delta \text { myel }}$ infectados com S. aureus ocorre.

Além da expressão de Colla3, também observamos um aumento da expressão de outros genes relacionados ao perfil M2 de macrófagos: Chi3l1 e Cd36 (229-231) na pele de aniamis miR2 $1^{\Delta \text { myel }}$ infectados com $S$. aureus. Estudos demonstram que o receptor CD36 está envolvido tanto na eliminação de $S$. aureus quanto de células apoptóticas $(124,126,252)$. Animais deficientes de CD36 tem um prejuízo no controle da infecção por S. aureus, desencadeando um aumento da bacteremia e diminuição na produção de citocinas (253). O aumento de CD36 em fagócitos de animais miR21 $1^{\Delta \text { myel }}$ pode tanto estar relacionado com a diminuição da carga bacteriana observada na pele desses animais quanto estar relacionado com a hipótese de maior eliminação de células mortas e, consequentemente, menor liberação de IL-1 $\alpha$ observada. Experimentos utilizando animais deficientes para CD36 ou inibidores de CD36, na presença ou não de miR-21, poderiam nos ajudar confirmar essa hipótese.

Nossos dados sugerem que a ausência de miR-21 favorece a resolução da infecção de $S$. aureus por diferentes vias: $i$ ) geração de macrófagos M2 que atuam no aumento da espessura da cápsula do abscesso (evitando a dispersão bacteriana a outros tecidos) e eferocitose de células mortas, ii) aumento da expressão de CD36 (favorecendo a eliminação tanto do patógeno como de células mortas, inibindo a liberação de DAMPs no tecido) e iii) produção tanto com citocinas inflamatórias quanto anti-inflamatórias que favoreceriam a eliminação do patógeno sem o excesso de inflamação.

Prévios estudos demonstraram que miR-21 modula negativamente a via de sinalização de NF-kB dependente de MyD88 (83, 210, 235, 254). MyD88 é uma proteína adaptadora essencial tanto para a sinalização decorrente da ativação de TLR, 
exceto TLR3, quanto para receptores da família de IL-1 $(211,212)$. Diversos estudos demonstram a importância dessa via de sinalização durante a infecção por S. aureus nos mais diferentes modelos. Animais deficientes para a molécula de MyD88 ou para receptor de IL-1 apresentam quadros mais severos de osteomielite causados por $S$. aureus (216). Hanke e colaboradores demonstraram que a molécula de MyD88 controla a formação de biofilmes de $S$. aureus em cateteres uma vez que animais deficiente de MyD88 apresentam: i) um aumento do biofilme tanto no cateter quanto nos tecidos adjacentes a este que coincide com aumento da disseminação bacteriana para coração e rins e ii) aumento da deposição de colágenos associado com um aumento do recrutamento de macrófagos M2 na região do cateter (255). Além disso, animais deficientes de MyD88 são mais susceptíveis a infecção de pele causadas por S. aureus (217). Nós observamos que miR-21 é capaz de inibir a expressão de $M y D 88$. O tratamento tópico com antagomiR-21 que havia demonstrado uma melhora das respostas do hospedeiro frente a infecção por S. aureus, quando combinado com um peptídeo inibidor de MyD88 perde seu efeito protetor, indicando que a melhora nas respostas de animais miR $21^{\Delta \text { myel }}$ se dá pela não inibição da via de sinalização de MyD88.

Assim, nós sugerimos que miR-21 é capaz de inibir a expressão de MyD88 prejudicando as respostas contra $S$. aureus em animais WT. Na ausência da molécula de miR-21, a via de sinalização de MyD88 é favorecida culmindo na produção de um microambiente balanceado com a presença tanto de IL-1 $\beta$ e TNF- $\alpha$ como de IL-10 que colaboram para o controle da infecção. Além disso, a ausência da molécula de miR-21 favorece um acúmulo de macrófagos M2 contribuindo para o aumento da deposição de colágeno na região de cápsula do abscesso que podem estar relacionados com o aumento da eferocitose via CD36 evitando a liberação de DAMPs nesse microambiente.

Entretanto, algumas questões ainda permanecem abertas em nosso trabalho, como por exemplo, $i$ ) determinar o gatilho para o aumento da expressão de miR-21 em nosso modelo, ii) quais os mecanismos que levam um aumento da população M2 de macrófagos na ausência da molécula de miR-21 durante a infecção por S. aureus, iii) o aumento da expressão de CD36 realmente está associado a eliminação de células mortas evitando um aumento na liberação de DAMPs nesse tecido, $i v$ ) IL-10 é importante para 
equilibrar o microambiente de forma a controlar o excesso de inflamação ou é apenas uma consequência do aumento da população de macrófagos M2 nesse tecido. 


\section{CONCLUSÃO}

O conjunto desses resultados demonstram que a expressão de microRNA-21 prejudica a resolução das infecções de pele causadas por $S$. aureus por inibir a via de sinalização de MyD88 e a geração de macrófagos M2. 


\section{BIBLIOGRAFIA}

1. Turvey SE, Broide DH. Innate immunity. Journal of Allergy and Clinical Immunology. 2010;125(2):S24-S32.

2. Jan R. Understanding Apoptosis and Apoptotic Pathways Targeted Cancer Therapeutics. Advanced pharmaceutical bulletin. 2019;9(2):205.

3. Morioka S, Maueröder C, Ravichandran KS. Living on the Edge: Efferocytosis at the Interface of Homeostasis and Pathology. Immunity. 2019;50(5):1149-62.

4. Cao W, Murao K, Imachi H, Hiramine C, Abe H, Yu X, et al. Phosphatidylserine receptor cooperates with high-density lipoprotein receptor in recognition of apoptotic cells by thymic nurse cells. Journal of molecular endocrinology. 2004;32(2):497-505.

5. Dogusan Z, Montecino-Rodriguez E, Dorshkind K. Macrophages and stromal cells phagocytose apoptotic bone marrow-derived B lineage cells. The Journal of Immunology. 2004;172(8):4717-23.

6. Antonelou $\mathrm{MH}$, Kriebardis $\mathrm{AG}$, Papassideri IS. Aging and death signalling in mature red cells: from basic science to transfusion practice. Blood Transfusion. 2010;8(Suppl 3):s39.

7. Elliott MR, Ravichandran KS. The dynamics of apoptotic cell clearance. Developmental cell. 2016;38(2):147-60.

8. Ravichandran KS. Find-me and eat-me signals in apoptotic cell clearance: progress and conundrums. Journal of Experimental Medicine. 2010;207(9):1807-17.

9. Hochreiter-Hufford AE, Lee CS, Kinchen JM, Sokolowski JD, Arandjelovic S, Call JA, et al. Phosphatidylserine receptor BAI1 and apoptotic cells as new promoters of myoblast fusion. Nature. 2013;497(7448):263-7.

10. Park D, Tosello-Trampont AC, Elliott MR, Lu M, Haney LB, Ma Z, et al. BAI1 is an engulfment receptor for apoptotic cells upstream of the ELMO/Dock180/Rac module. Nature. 2007;450(7168):430-4.

11. Park SY, Jung MY, Kim HJ, Lee SJ, Kim SY, Lee BH, et al. Rapid cell corpse clearance by stabilin-2, a membrane phosphatidylserine receptor. Cell death and differentiation. 2008;15(1):192-201.

12. Park SY, Kim SY, Jung MY, Bae DJ, Kim IS. Epidermal growth factor-like domain repeat of stabilin-2 recognizes phosphatidylserine during cell corpse clearance. Molecular and cellular biology. 2008;28(17):5288-98.

13. He M, Kubo H, Morimoto K, Fujino N, Suzuki T, Takahasi T, et al. Receptor for advanced glycation end products binds to phosphatidylserine and assists in the clearance of apoptotic cells. EMBO reports. 2011;12(4):358-64.

14. Miyanishi M, Tada K, Koike M, Uchiyama Y, Kitamura T, Nagata S. Identification of Tim4 as a phosphatidylserine receptor. Nature. 2007;450(7168):435-9.

15. Kobayashi N, Karisola P, Pena-Cruz V, Dorfman DM, Jinushi M, Umetsu SE, et al. TIM-1 and TIM-4 glycoproteins bind phosphatidylserine and mediate uptake of apoptotic cells. Immunity. 2007;27(6):927-40.

16. Platt N, Suzuki H, Kurihara Y, Kodama T, Gordon S. Role for the class A macrophage scavenger receptor in the phagocytosis of apoptotic thymocytes in vitro. Proceedings of the National Academy of Sciences of the United States of America. 1996;93(22):12456-60.

17. Greenberg ME, Sun M, Zhang R, Febbraio M, Silverstein R, Hazen SL. Oxidized phosphatidylserine-CD36 interactions play an essential role in macrophage-dependent phagocytosis of apoptotic cells. J Exp Med. 2006;203(12):2613-25.

18. Hall MO, Obin MS, Heeb MJ, Burgess BL, Abrams TA. Both protein S and Gas6 stimulate outer segment phagocytosis by cultured rat retinal pigment epithelial cells. Experimental eye research. 2005;81(5):581-91. 
19. Roos A, Xu W, Castellano G, Nauta AJ, Garred P, Daha MR, et al. Mini-review: a pivotal role for innate immunity in the clearance of apoptotic cells. European journal of immunology. 2004;34(4):921-9.

20. Gardai SJ, McPhillips KA, Frasch SC, Janssen WJ, Starefeldt A, Murphy-Ullrich JE, et al. Cell-surface calreticulin initiates clearance of viable or apoptotic cells through transactivation of LRP on the phagocyte. Cell. 2005;123(2):321-34.

21. Hochreiter-Hufford A, Ravichandran KS. Clearing the dead: apoptotic cell sensing, recognition, engulfment, and digestion. Cold Spring Harbor perspectives in biology. 2013;5(1):a008748.

22. Martin S, Pombo I, Poncet P, David B, Arock M, Blank U. Immunologic stimulation of mast cells leads to the reversible exposure of phosphatidylserine in the absence of apoptosis. International archives of allergy and immunology. 2000;123(3):249-58.

23. Elliott JI, Surprenant A, Marelli-Berg FM, Cooper JC, Cassady-Cain RL, Wooding C, et al. Membrane phosphatidylserine distribution as a non-apoptotic signalling mechanism in lymphocytes. Nature cell biology. 2005;7(8):808-16.

24. Dias-Baruffi M, Zhu H, Cho M, Karmakar S, McEver RP, Cummings RD. Dimeric galectin-1 induces surface exposure of phosphatidylserine and phagocytic recognition of leukocytes without inducing apoptosis. Journal of Biological Chemistry. 2003;278(42):4128293.

25. Miksa M, Amin D, Wu R, Dong W, Ravikumar TS, Wang P. Fractalkine-induced MFG-E8 leads to enhanced apoptotic cell clearance by macrophages. Molecular Medicine. 2007;13(11-12):553-60.

26. Murugesan G, Rani MS, Gerber CE, Mukhopadhyay C, Ransohoff RM, Chisolm GM, et al. Lysophosphatidylcholine regulates human microvascular endothelial cell expression of chemokines. Journal of molecular and cellular cardiology. 2003;35(11):1375-84.

27. Murphy PS, Wang J, Bhagwat SP, Munger JC, Janssen WJ, Wright TW, et al. CD73 regulates anti-inflammatory signaling between apoptotic cells and endotoxin-conditioned tissue macrophages. Cell Death \& Differentiation. 2017.

28. Weigert A, Tzieply N, Von Knethen A, Johann AM, Schmidt H, Geisslinger G, et al. Tumor cell apoptosis polarizes macrophages-role of sphingosine-1-phosphate. Molecular biology of the cell. 2007;18(10):3810-9.

29. Arandjelovic S, Ravichandran KS. Phagocytosis of apoptotic cells in homeostasis. Nature immunology. 2015;16(9):907.

30. Ghavami S, Shojaei S, Yeganeh B, Ande SR, Jangamreddy JR, Mehrpour M, et al. Autophagy and apoptosis dysfunction in neurodegenerative disorders. Progress in neurobiology. 2014;112:24-49.

31. van Eeden SF, Hogg JC. Immune-Modulation in Chronic Obstructive Pulmonary Disease: Current Concepts and Future Strategies. Respiration. 2019:1-16.

32. Korns D, Frasch SC, Fernandez-Boyanapalli R, Henson PM, Bratton DL. Modulation of macrophage efferocytosis in inflammation. Macrophages in inflammation and its resolution. 2011:62.

33. Torchinsky MB, Garaude J, Martin AP, Blander JM. Innate immune recognition of infected apoptotic cells directs T(H)17 cell differentiation. Nature. 2009;458(7234):78-82.

34. Fadok VA, Bratton DL, Konowal A, Freed PW, Westcott JY, Henson PM. Macrophages that have ingested apoptotic cells in vitro inhibit proinflammatory cytokine production through autocrine/paracrine mechanisms involving TGF-beta, PGE2, and PAF. J Clin Invest. 1998;101(4):890-8.

35. Medeiros AI, Serezani CH, Lee SP, Peters-Golden M. Efferocytosis impairs pulmonary macrophage and lung antibacterial function via PGE2/EP2 signaling. Journal of Experimental Medicine. 2009;206(1):61-8. 
36. Brereton CF, Blander JM. Responding to infection and apoptosis--a task for TH17 cells. Ann N Y Acad Sci. 2010;1209:56-67.

37. Takeuchi O, Akira S. Pattern recognition receptors and inflammation. Cell. 2010;140(6):805-20.

38. Takeda K, Akira S. Toll-like receptors. Curr Protoc Immunol. 2015;109:14 2 1- 20.

39. Zhang Z, Clarke TB, Weiser JN. Cellular effectors mediating Th17-dependent clearance of pneumococcal colonization in mice. The Journal of clinical investigation. 2009;119(7):1899909.

40. van Rossum AM, Lysenko ES, Weiser JN. Host and bacterial factors contributing to the clearance of colonization by Streptococcus pneumoniae in a murine model. Infect Immun. 2005;73(11):7718-26.

41. Koppe U, Suttorp N, Opitz B. Recognition of Streptococcus pneumoniae by the innate immune system. Cell Microbiol. 2012;14(4):460-6.

42. Branger J, Knapp S, Weijer S, Leemans JC, Pater JM, Speelman P, et al. Role of Tolllike receptor 4 in gram-positive and gram-negative pneumonia in mice. Infection and immunity. 2004;72(2):788-94.

43. Dessing MC, Schouten M, Draing C, Levi M, von Aulock S, van der Poll T. Role played by Toll-like receptors 2 and 4 in lipoteichoic acid-induced lung inflammation and coagulation. J Infect Dis. 2008;197(2):245-52.

44. Klein M, Obermaier B, Angele B, Pfister HW, Wagner H, Koedel U, et al. Innate immunity to pneumococcal infection of the central nervous system depends on toll-like receptor (TLR) 2 and TLR4. The Journal of infectious diseases. 2008;198(7):1028-36.

45. Oviedo-Boyso J, Bravo-Patiño A, Baizabal-Aguirre VM. Collaborative action of Tolllike and Nod-like receptors as modulators of the inflammatory response to pathogenic bacteria. Mediators Inflamm. 2014.

46. Motta V, Soares F, Sun T, Philpott DJ. NOD-like receptors: versatile cytosolic sentinels. Physiological reviews. 2015;95(1):149-78.

47. Kim YK, Shin J-S, Nahm MH. NOD-like receptors in infection, immunity, and diseases. Yonsei medical journal. 2016;57(1):5-14.

48. Yang Y, Wang H, Kouadir M, Song H, Shi F. Recent advances in the mechanisms of NLRP3 inflammasome activation and its inhibitors. Cell death \& disease. 2019;10(2):128.

49. McNeela EA, Burke A, Neill DR, Baxter C, Fernandes VE, Ferreira D, et al. Pneumolysin activates the NLRP3 inflammasome and promotes proinflammatory cytokines independently of TLR4. PLoS pathogens. 2010;6(11):e1001191.

50. Witzenrath M, Pache F, Lorenz D, Koppe U, Gutbier B, Tabeling C, et al. The NLRP3 inflammasome is differentially activated by pneumolysin variants and contributes to host defense in pneumococcal pneumonia. J Immunol. 2011;187(1):434-40.

51. Fang R, Tsuchiya K, Kawamura I, Shen Y, Hara H, Sakai S, et al. Critical roles of ASC inflammasomes in caspase-1 activation and host innate resistance to Streptococcus pneumoniae infection. The Journal of Immunology. 2011;187(9):4890-9.

52. Hua K-F, Yang F-L, Chiu H-W, Chou J-C, Dong W-C, Lin C-N, et al. Capsular polysaccharide is involved in NLRP3 inflammasome activation by Klebsiella pneumoniae serotype K1. Infection and immunity. 2015;83(9):3396-409.

53. Yi Y-S. Regulatory Roles of the Caspase-11 Non-Canonical Inflammasome in Inflammatory Diseases. Immune network. 2018;18(6).

54. Amarante-Mendes GP, Adjemian S, Branco LM, Zanetti LC, Weinlich R, Bortoluci KR. Pattern recognition receptors and the host cell death molecular machinery. Frontiers in immunology. 2018;9:2379.

55. Wang J, Shao Y, Wang W, Li S, Xin N, Xie F, et al. Caspase-11 deficiency impairs neutrophil recruitment and bacterial clearance in the early stage of pulmonary Klebsiella pneumoniae infection. International Journal of Medical Microbiology. 2017;307(8):490-6. 
56. Zanoni I, Tan Y, Di Gioia M, Broggi A, Ruan J, Shi J, et al. An endogenous caspase-11 ligand elicits interleukin-1 release from living dendritic cells. Science. 2016;352(6290):1232-6.

57. Zanoni I, Tan Y, Di Gioia M, Springstead JR, Kagan JC. By capturing inflammatory lipids released from dying cells, the receptor CD14 induces inflammasome-dependent phagocyte hyperactivation. Immunity. 2017;47(4):697-709. e3.

58. Davies LC, Taylor PR. Tissue-resident macrophages: then and now. Immunology. 2015;144(4):541-8.

59. Ginhoux F, Jung S. Monocytes and macrophages: developmental pathways and tissue homeostasis. Nature Reviews Immunology. 2014;14(6):392-404.

60. Sica A, Erreni M, Allavena P, Porta C. Macrophage polarization in pathology. Cellular and molecular life sciences. 2015;72(21):4111-26.

61. Arango Duque G, Descoteaux A. Macrophage cytokines: involvement in immunity and infectious diseases. Front Immunol. 2014;5:491.

62. Sica A, Schioppa T, Mantovani A, Allavena P. Tumour-associated macrophages are a distinct M2 polarised population promoting tumour progression: potential targets of anti-cancer therapy. Eur J Cancer. 2006;42(6):717-27.

63. Vega M, Corbí A. Human macrophage activation: too many functions and phenotypes for a single cell type. Inmunologia. 2006;25:248-72.

64. Shapouri-Moghaddam A, Mohammadian S, Vazini H, Taghadosi M, Esmaeili SA, Mardani F, et al. Macrophage plasticity, polarization, and function in health and disease. Journal of cellular physiology. 2018;233(9):6425-40.

65. Atri C, Guerfali FZ, Laouini D. Role of human macrophage polarization in inflammation during infectious diseases. International journal of molecular sciences. 2018;19(6): 1801 .

66. Biswas SK, Mantovani A. Orchestration of metabolism by macrophages. Cell metabolism. 2012;15(4):432-7.

67. Wilson HM. SOCS proteins in macrophage polarization and function. M1/M2 Macrophages: The Arginine Fork in the Road to Health and Disease. 2015:239.

68. Herd HL, Bartlett KT, Gustafson JA, McGill LD, Ghandehari H. Macrophage silica nanoparticle response is phenotypically dependent. Biomaterials. 2015;53:574-82.

69. Cassetta L, Cassol E, Poli G. Macrophage polarization in health and disease. The Scientific World Journal. 2011;11:2391-402.

70. Raes G, Van den Bergh R, De Baetselier P, Ghassabeh GH, Scotton C, Locati M, et al. Arginase-1 and Ym1 are markers for murine, but not human, alternatively activated myeloid cells. J Immunol. 2005;174(11):6561; author reply -2.

71. Hesse M, Modolell M, La Flamme AC, Schito M, Fuentes JM, Cheever AW, et al. Differential regulation of nitric oxide synthase- 2 and arginase- 1 by type 1/type 2 cytokines in vivo: granulomatous pathology is shaped by the pattern of L-arginine metabolism. J Immunol. 2001;167(11):6533-44.

72. Martinez FO, Helming L, Gordon S. Alternative activation of macrophages: an immunologic functional perspective. Annu Rev Immunol. 2009;27:451-83.

73. Voll RE, Herrmann M, Roth EA, Stach C, Kalden JR, Girkontaite I. Immunosuppressive effects of apoptotic cells. Nature. 1997;390(6658):350-1.

74. Köröskényi K, Duró E, Pallai A, Sarang Z, Kloor D, Ucker DS, et al. Involvement of adenosine A2A receptors in engulfment-dependent apoptotic cell suppression of inflammation. The Journal of immunology. 2011;186(12):7144-55.

75. Yamaguchi H, Maruyama T, Urade Y, Nagata S. Immunosuppression via adenosine receptor activation by adenosine monophosphate released from apoptotic cells. Elife. 2014;3:e2172.

76. Elliott MR, Koster KM, Murphy PS. Efferocytosis signaling in the regulation of macrophage inflammatory responses. The Journal of Immunology. 2017;198(4):1387-94. 
77. Ariel A, Serhan CN. New lives given by cell death: macrophage differentiation following their encounter with apoptotic leukocytes during the resolution of inflammation. Frontiers in immunology. 2012;3:4.

78. Boada-Romero E, Martinez J, Heckmann BL, Green DR. The clearance of dead cells by efferocytosis. Nature Reviews Molecular Cell Biology. 2020:1-17.

79. Martinez J, Cunha LD, Park S, Yang M, Lu Q, Orchard R, et al. Noncanonical autophagy inhibits the autoinflammatory, lupus-like response to dying cells. Nature. 2016;533(7601):115-9.

80. Cunha LD, Yang M, Carter R, Guy C, Harris L, Crawford JC, et al. LC3-associated phagocytosis in myeloid cells promotes tumor immune tolerance. Cell. 2018;175(2):429-41. e16.

81. Wang N, Liang H, Zen K. Molecular mechanisms that influence the macrophage m1$\mathrm{m} 2$ polarization balance. Frontiers in immunology. 2014;5:614.

82. Sica A, Mantovani A. Macrophage plasticity and polarization: in vivo veritas. The Journal of clinical investigation. 2012;122(3):787-95.

83. Wang Z, Brandt S, Medeiros A, Wang S, Wu H, Dent A, et al. MicroRNA 21 is a homeostatic regulator of macrophage polarization and prevents prostaglandin E2-mediated M2 generation. PloS one. 2015;10(2):e0115855.

84. Qu Y, Misaghi S, Newton K, Maltzman A, Izrael-Tomasevic A, Arnott D, et al. NLRP3 recruitment by NLRC4 during Salmonella infection. Journal of Experimental Medicine. 2016;213(6):877-85.

85. Metcalf D, Nicola N. The clonal proliferation of normal mouse hematopoietic cells: enhancement and suppression by colony-stimulating factor combinations. 1992.

86. Livak KJ, Schmittgen TD. Analysis of relative gene expression data using real-time quantitative PCR and the 2(-Delta Delta C(T)) Method. Methods. 2001;25(4):402-8.

87. Hibbs JB, Jr., Taintor RR, Vavrin Z, Rachlin EM. Nitric oxide: a cytotoxic activated macrophage effector molecule. Biochemical and biophysical research communications. 1988;157(1):87-94.

88. Hentze H, Latta M, Künstle G, Dhakshinamoorthy S, Ng PY, Porter AG, et al. Topoisomerase inhibitor camptothecin sensitizes mouse hepatocytes in vitro and in vivo to TNF-mediated apoptosis. Hepatology. 2004;39(5):1311-20.

89. Chan WH, Yu JS. Inhibition of UV irradiation-induced oxidative stress and apoptotic biochemical changes in human epidermal carcinoma A431 cells by genistein. Journal of cellular biochemistry. 2000;78(1):73-84.

90. Echchannaoui H, Frei K, Schnell C, Leib SL, Zimmerli W, Landmann R. Toll-like receptor 2-deficient mice are highly susceptible to Streptococcus pneumoniae meningitis because of reduced bacterial clearing and enhanced inflammation. J Infect Dis. 2002;186(6):798-806.

91. Jeon H-Y, Park J-H, Park J-I, Kim J-Y, Seo S-M, Ham S-H, et al. Cooperative Interactions between Toll-Like Receptor 2 and Toll-Like Receptor 4 in Murine Klebsiella pneumoniae Infections. Journal of microbiology and biotechnology. 2017;27(8):1529-38.

92. Blander JM, Medzhitov R. Toll-dependent selection of microbial antigens for presentation by dendritic cells. Nature. 2006;440(7085):808-12.

93. Blander JM, Medzhitov R. On regulation of phagosome maturation and antigen presentation. Nature immunology. 2006;7(10):1029-35.

94. Wang N, Liang H, Zen K. Molecular mechanisms that influence the macrophage M1M2 polarization balance. Frontiers in immunology. 2014;5:614.

95. Dixit V, Mak TW. NF-אB signaling: many roads lead to Madrid. Cell. 2002;111(5):6159.

96. Pertovaara M, Silvennoinen O, Isomäki P. Cytokine-induced STAT1 activation is increased in patients with primary Sjögren's syndrome. Clinical Immunology. 2016;165:60-7. 
97. Tugal D, Liao X, Jain MK. Transcriptional control of macrophage polarization. Arteriosclerosis, thrombosis, and vascular biology. 2013;33(6):1135-44.

98. Lawrence DW, Kornbluth J. Reduced inflammation and cytokine production in NKLAM deficient mice during Streptococcus pneumoniae infection. PloS one. 2018;13(3).

99. Chen T-T, Tsai M-H, Kung JT, Lin K-I, Decker T, Lee C-K. STAT1 regulates marginal zone $\mathrm{B}$ cell differentiation in response to inflammation and infection with blood-borne bacteria. Journal of Experimental Medicine. 2016;213(13):3025-39.

100. Poe SL, Arora M, Oriss TB, Yarlagadda M, Isse K, Khare A, et al. STAT1-regulated lung MDSC-like cells produce IL-10 and efferocytose apoptotic neutrophils with relevance in resolution of bacterial pneumonia. Mucosal immunology. 2013;6(1):189-99.

101. Jamwal SV, Mehrotra P, Singh A, Siddiqui Z, Basu A, Rao KV. Mycobacterial escape from macrophage phagosomes to the cytoplasm represents an alternate adaptation mechanism. Scientific reports. 2016;6:23089.

102. Moldovan A, Fraunholz MJ. In or out: phagosomal escape of Staphylococcus aureus. Cellular microbiology. 2019;21(3):e12997.

103. Paetzold S, Lourido S, Raupach B, Zychlinsky A. Shigella flexneri phagosomal escape is independent of invasion. Infection and immunity. 2007;75(10):4826-30.

104. Lopez-Castejon G, Corbett D, Goldrick M, Roberts IS, Brough D. Inhibition of calpain blocks the phagosomal escape of Listeria monocytogenes. PloS one. 2012;7(4).

105. Napier BA, Meyer L, Bina JE, Miller MA, Sjöstedt A, Weiss DS. Link between intraphagosomal biotin and rapid phagosomal escape in Francisella. Proceedings of the National Academy of Sciences. 2012;109(44):18084-9.

106. Codo AC, Saraiva AC, dos Santos LL, Visconde MF, Gales AC, Zamboni DS, et al. Inhibition of inflammasome activation by a clinical strain of Klebsiella pneumoniae impairs efferocytosis and leads to bacterial dissemination. Cell death \& disease. 2018;9(12):1-14.

107. Lemon JK, Weiser JN. Degradation products of the extracellular pathogen Streptococcus pneumoniae access the cytosol via its pore-forming toxin. MBio. 2015;6(1):e02110-14.

108. Flood B, Manils J, Nulty C, Flis E, Kenealy S, Barber G, et al. Caspase-11 regulates the tumour suppressor function of STAT1 in a murine model of colitis-associated carcinogenesis. Oncogene. 2019;38(14):2658-74.

109. Dejani NN, Orlando AB, Niño VE, de Aquino Penteado L, Verdan FF, Bazzano JMR, et al. Intestinal host defense outcome is dictated by PGE2 production during efferocytosis of infected cells. Proceedings of the National Academy of Sciences. 2018;115(36):E8469-E78.

110. Watanabe Y, Shiratsuchi A, Shimizu K, Takizawa T, Nakanishi Y. Role of phosphatidylserine exposure and sugar chain desialylation at the surface of influenza virusinfected cells in efficient phagocytosis by macrophages. Journal of Biological Chemistry. 2002;277(20):18222-8.

111. Shiratsuchi A, Kaido M, Takizawa T, Nakanishi Y. Phosphatidylserine-mediated phagocytosis of influenza A virus-infected cells by mouse peritoneal macrophages. Journal of Virology. 2000;74(19):9240-4.

112. Bhattacharyya S, Zagórska A, Lew ED, Shrestha B, Rothlin CV, Naughton J, et al. Enveloped viruses disable innate immune responses in dendritic cells by direct activation of TAM receptors. Cell host \& microbe. 2013;14(2):136-47.

113. Liu B, Di Meng TW, Zhang S, Hu Y, Wang M. Apoptosis and pro-inflammatory cytokine response of mast cells induced by influenza A viruses. PLoS One. 2014;9(6).

114. van Zandbergen G, Bollinger A, Wenzel A, Kamhawi S, Voll R, Klinger M, et al. Leishmania disease development depends on the presence of apoptotic promastigotes in the virulent inoculum. Proceedings of the National Academy of Sciences. 2006;103(37):13837-42. 
115. van Zandbergen G, Klinger M, Mueller A, Dannenberg S, Gebert A, Solbach W, et al. Cutting edge: neutrophil granulocyte serves as a vector for Leishmania entry into macrophages. The Journal of Immunology. 2004;173(11):6521-5.

116. Ribeiro-Gomes FL, Otero AC, Gomes NA, Moniz-de-Souza MCA, Cysne-Finkelstein L, Arnholdt AC, et al. Macrophage interactions with neutrophils regulate Leishmania major infection. The Journal of Immunology. 2004;172(7):4454-62.

117. Oliveira A-C, Peixoto JR, de Arruda LB, Campos MA, Gazzinelli RT, Golenbock DT, et al. Expression of functional TLR4 confers proinflammatory responsiveness to Trypanosoma cruzi glycoinositolphospholipids and higher resistance to infection with T. cruzi. The Journal of Immunology. 2004;173(9):5688-96.

118. Hu B, Jennings JH, Sonstein J, Floros J, Todt JC, Polak T, et al. Resident murine alveolar and peritoneal macrophages differ in adhesion of apoptotic thymocytes. American journal of respiratory cell and molecular biology. 2004;30(5):687-93.

119. Kourtzelis I, Li X, Mitroulis I, Grosser D, Kajikawa T, Wang B, et al. DEL-1 promotes macrophage efferocytosis and clearance of inflammation. Nature immunology. 2019;20(1):40-9.

120. Salina AC, Souza TP, Serezani CH, Medeiros AI. Efferocytosis-induced prostaglandin E2 production impairs alveolar macrophage effector functions during Streptococcus pneumoniae infection. Innate immunity. 2017;23(3):219-27.

121. Zhao Y-l, Tian P-x, Han F, Zheng J, Xia X-x, Xue W-j, et al. Comparison of the characteristics of macrophages derived from murine spleen, peritoneal cavity, and bone marrow. Journal of Zhejiang University-SCIENCE B. 2017;18(12):1055-63.

122. Zhong X, Lee H-N, Kim SH, Park S-A, Kim W, Cha Y-N, et al. Myc-nick promotes efferocytosis through M2 macrophage polarization during resolution of inflammation. The FASEB Journal. 2018;32(10):5312-25.

123. Röszer T. Understanding the mysterious M2 macrophage through activation markers and effector mechanisms. Mediators of inflammation. 2015;2015.

124. Greenberg ME, Sun M, Zhang R, Febbraio M, Silverstein R, Hazen SL. Oxidized phosphatidylserine-CD36 interactions play an essential role in macrophage-dependent phagocytosis of apoptotic cells. The Journal of experimental medicine. 2006;203(12):2613-25.

125. Huynh M-LN, Fadok VA, Henson PM. Phosphatidylserine-dependent ingestion of apoptotic cells promotes TGF- $\beta 1$ secretion and the resolution of inflammation. The Journal of clinical investigation. 2002;109(1):41-50.

126. Ferracini M, Rios FJ, Pecenin M, Jancar S. Clearance of apoptotic cells by macrophages induces regulatory phenotype and involves stimulation of CD36 and platelet-activating factor receptor. Mediators of inflammation. 2013;2013.

127. Gheibi Hayat SM, Bianconi V, Pirro M, Sahebkar A. Efferocytosis: molecular mechanisms and pathophysiological perspectives. Immunology and cell biology. 2019;97(2):124-33.

128. Kadioglu A, Andrew PW. The innate immune response to pneumococcal lung infection: the untold story. Trends in immunology. 2004;25(3):143-9.

129. Smith MW, Schmidt JE, Rehg JE, Orihuela CJ, McCullers JA. Induction of pro-and anti-inflammatory molecules in a mouse model of pneumococcal pneumonia after influenza. Comparative medicine. 2007;57(1):82-9.

130. Knippenberg S, Brumshagen C, Aschenbrenner F, Welte T, Maus UA. Arginase 1 activity worsens lung-protective immunity against Streptococcus pneumoniae infection. European journal of immunology. 2015;45(6):1716-26.

131. Köffel R, Wolfmeier H, Larpin Y, Besançon H, Schoenauer R, Babiychuk VS, et al. Host-derived microvesicles carrying bacterial pore-forming toxins deliver signals to macrophages: a novel mechanism of shaping immune responses. Frontiers in immunology. 2018;9:1688. 
132. Goldmann O, von Köckritz-Blickwede M, Höltje C, Chhatwal GS, Geffers R, Medina E. Transcriptome analysis of murine macrophages in response to infection with Streptococcus pyogenes reveals an unusual activation program. Infection and immunity. 2007;75(8):4148-57.

133. Fevre C, Almeida AS, Taront S, Pedron T, Huerre M, Prevost MC, et al. A novel murine model of rhinoscleroma identifies Mikulicz cells, the disease signature, as IL-10 dependent derivatives of inflammatory monocytes. EMBO molecular medicine. 2013;5(4):51630 .

134. Dumigan A, Fitzgerald M, Santos JS-PG, Hamid U, O'Kane CM, McAuley DF, et al. A porcine ex vivo lung perfusion model to investigate bacterial pathogenesis. mBio. 2019;10(6).

135. Akira S, Takeda K. Functions of toll-like receptors: lessons from KO mice. C R Biol. 2004;327(6):581-9.

136. Tomlinson G, Chimalapati S, Pollard T, Lapp T, Cohen J, Camberlein E, et al. TLRmediated inflammatory responses to Streptococcus pneumoniae are highly dependent on surface expression of bacterial lipoproteins. The Journal of Immunology. 2014;193(7):3736-45.

137. Shi J, Li Q, Sheng M, Zheng M, Yu M, Zhang L. The role of TLR4 in M1 macrophageinduced epithelial-mesenchymal transition of peritoneal mesothelial cells. Cellular Physiology and Biochemistry. 2016;40(6):1538-48.

138. Hunt JJ, Astley R, Wheatley N, Wang J-T, Callegan MC. TLR4 contributes to the host response to Klebsiella intraocular infection. Current eye research. 2014;39(8):790-802.

139. Liu C-P, Zhang X, Tan Q-L, Xu W-X, Zhou C-Y, Luo M, et al. NF- $\kappa B$ pathways are involved in M1 polarization of RAW 264.7 macrophage by polyporus polysaccharide in the tumor microenvironment. PLoS One. 2017;12(11).

140. Liu Y, Fang S, Li X, Feng J, Du J, Guo L, et al. Aspirin inhibits LPS-induced

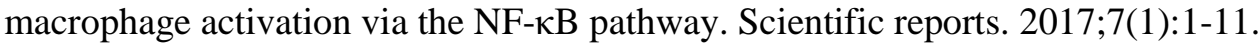

141. Fong CHY, Bebien M, Didierlaurent A, Nebauer R, Hussell T, Broide D, et al. An antiinflammatory role for IKK $\beta$ through the inhibition of "classical" macrophage activation. The Journal of experimental medicine. 2008;205(6):1269-76.

142. Porta C, Rimoldi M, Raes G, Brys L, Ghezzi P, Di Liberto D, et al. Tolerance and M2 (alternative) macrophage polarization are related processes orchestrated by p50 nuclear factor $\kappa B$. Proceedings of the National Academy of Sciences. 2009;106(35):14978-83.

143. Szondy Z, Sarang Z, Kiss B, Garabuczi É, Köröskényi K. Anti-inflammatory mechanisms triggered by apoptotic cells during their clearance. Frontiers in immunology. 2017;8:909.

144. Mburu YK, Egloff AM, Walker WH, Wang L, Seethala RR, Van Waes C, et al. Chemokine receptor 7 (CCR7) gene expression is regulated by NF- $\mathrm{KB}$ and activator protein 1 (AP1) in metastatic squamous cell carcinoma of head and neck (SCCHN). Journal of Biological Chemistry. 2012;287(5):3581-90.

145. Mburu Y, Egloff AM, Wang L, Seethala R, Walker W, Van Waes C, et al. Regulation of Chemokine Receptor 7 expression by NF- $\kappa B$ in Squamous Cell Carcinoma of the Head and Neck (149.3). Am Assoc Immnol; 2011.

146. Zou GM, Hu WY. LIGHT regulates CD86 expression on dendritic cells through NF- $\kappa \mathrm{B}$, but not JNK/AP-1 signal transduction pathway. Journal of cellular physiology. 2005;205(3):437-43.

147. Podojil JR, Kin NW, Sanders VM. CD86 and $\beta 2$-adrenergic receptor signaling pathways, respectively, increase Oct-2 and OCA-B expression and binding to the 3 '-IgH enhancer in B cells. Journal of Biological Chemistry. 2004;279(22):23394-404.

148. Shen J, Sun X, Pan B, Cao S, Cao J, Che D, et al. IL-17 induces macrophages to M2like phenotype via NF- $\kappa$ B. Cancer management and research. 2018;10:4217.

149. Ichimura T, Asseldonk EJ, Humphreys BD, Gunaratnam L, Duffield JS, Bonventre JV. Kidney injury molecule- 1 is a phosphatidylserine receptor that confers a phagocytic phenotype on epithelial cells. The Journal of clinical investigation. 2008;118(5):1657-68. 
150. Yang L, Brooks CR, Xiao S, Sabbisetti V, Yeung MY, Hsiao L-L, et al. KIM-1mediated phagocytosis reduces acute injury to the kidney. The Journal of clinical investigation. 2015;125(4):1620-36.

151. Sen P, Wallet MA, Yi Z, Huang Y, Henderson M, Mathews CE, et al. Apoptotic cells induce Mer tyrosine kinase-dependent blockade of NF- $\mathrm{KB}$ activation in dendritic cells. Blood. 2007;109(2):653-60.

152. Mukundan L, Odegaard JI, Morel CR, Heredia JE, Mwangi JW, Ricardo-Gonzalez RR, et al. PPAR- $\delta$ senses and orchestrates clearance of apoptotic cells to promote tolerance. Nature medicine. 2009;15(11):1266.

153. Rothlin CV, Ghosh S, Zuniga EI, Oldstone MB, Lemke G. TAM receptors are pleiotropic inhibitors of the innate immune response. Cell. 2007;131(6):1124-36.

154. Rőszer T, Menéndez-Gutiérrez MP, Lefterova MI, Alameda D, Núñez V, Lazar MA, et al. Autoimmune kidney disease and impaired engulfment of apoptotic cells in mice with macrophage peroxisome proliferator-activated receptor $\gamma$ or retinoid X receptor $\alpha$ deficiency. The Journal of Immunology. 2011;186(1):621-31.

155. Crean D, Cummins EP, Bahar B, Mohan H, McMorrow JP, Murphy EP. Adenosine modulates NR4A orphan nuclear receptors to attenuate hyperinflammatory responses in monocytic cells. The Journal of Immunology. 2015;195(4):1436-48.

156. Tang F, Tang G, Xiang J, Dai Q, Rosner MR, Lin A. The absence of NF-kB-mediated inhibition of c-Jun N-terminal kinase activation contributes to tumor necrosis factor alphainduced apoptosis. Molecular and cellular biology. 2002;22(24):8571-9.

157. Karin M, Lin A. NF- $\mathrm{kB}$ at the crossroads of life and death. Nature immunology. 2002;3(3):221-7.

158. Weston CR, Davis RJ. The JNK signal transduction pathway. Current opinion in cell biology. 2007;19(2):142-9.

159. Hannemann N, Jordan J, Paul S, Reid S, Baenkler H-W, Sonnewald S, et al. The AP-1 transcription factor c-Jun promotes arthritis by regulating cyclooxygenase-2 and arginase-1 expression in macrophages. The Journal of Immunology. 2017;198(9):3605-14.

160. Relja B, Land WG. Damage-associated molecular patterns in trauma. European journal of trauma and emergency surgery. 2019:1-25.

161. Rijneveld AW, van den Dobbelsteen GP, Florquin S, Standiford TJ, Speelman P, van Alphen L, et al. Roles of interleukin-6 and macrophage inflammatory protein-2 in pneumolysin-induced lung inflammation in mice. The Journal of infectious diseases. 2002;185(1):123-6.

162. Jones MR, Quinton LJ, Simms BT, Lupa MM, Kogan MS, Mizgerd JP. Roles of interleukin-6 in activation of STAT proteins and recruitment of neutrophils during Escherichia coli pneumonia. The Journal of infectious diseases. 2006;193(3):360-9.

163. Gerhartz C, Heesel B, Sasse J, Hemmann U, Landgraf C, Schneider-Mergener J, et al. Differential activation of acute phase response factor/STAT3 and STAT1 via the cytoplasmic domain of the interleukin 6 signal transducer gp130 I. Definition of a novel phosphotyrosine motif mediating STAT1 activation. Journal of Biological Chemistry. 1996;271(22):12991-8.

164. Amaral EP, Riteau N, Moayeri M, Maier N, Mayer-Barber KD, Pereira RM, et al. Lysosomal cathepsin release is required for NLRP3-inflammasome activation by Mycobacterium tuberculosis in infected macrophages. Frontiers in immunology. 2018;9:1427.

165. Awad F, Assrawi E, Jumeau C, Georgin-Lavialle S, Cobret L, Duquesnoy P, et al. Impact of human monocyte and macrophage polarization on NLR expression and NLRP3 inflammasome activation. PloS one. 2017;12(4).

166. Ngoungoure FP, Owona BA. Withaferin A modulates AIM2 inflammasome and caspase-1 expression in THP-1 polarized macrophages. Experimental cell research. 2019;383(2):111564. 
167. Huang X, Feng Y, Xiong G, Whyte S, Duan J, Yang Y, et al. Caspase-11, a specific sensor for intracellular lipopolysaccharide recognition, mediates the non-canonical inflammatory pathway of pyroptosis. Cell \& bioscience. 2019;9(1):31.

168. Liu X, Lieberman J. A mechanistic understanding of pyroptosis: the fiery death triggered by invasive infection. Advances in immunology. 135: Elsevier; 2017. p. 81-117.

169. Swanson KV, Deng M, Ting JP-Y. The NLRP3 inflammasome: molecular activation and regulation to therapeutics. Nature Reviews Immunology. 2019;19(8):477-89.

170. Kayagaki N, Wong MT, Stowe IB, Ramani SR, Gonzalez LC, Akashi-Takamura S, et al. Noncanonical inflammasome activation by intracellular LPS independent of TLR4. Science. 2013;341(6151):1246-9.

171. Huber J, Vales A, Mitulovic G, Blumer M, Schmid R, Witztum JL, et al. Oxidized membrane vesicles and blebs from apoptotic cells contain biologically active oxidized phospholipids that induce monocyte-endothelial interactions. Arteriosclerosis, thrombosis, and vascular biology. 2002;22(1):101-7.

172. Devitt A, Pierce S, Oldreive C, Shingler W, Gregory C. CD14-dependent clearance of apoptotic cells by human macrophages: the role of phosphatidylserine. Cell Death \& Differentiation. 2003;10(3):371-82.

173. Cho SJ, Rooney K, Choi AM, Stout-Delgado HW. NLRP3 inflammasome activation in aged macrophages is diminished during Streptococcus pneumoniae infection. American Journal of Physiology-Lung Cellular and Molecular Physiology. 2018;314(3):L372-L87.

174. van Lieshout MH, de Vos AF, Dessing MC, de Porto AP, de Boer OJ, de Beer R, et al. ASC and NLRP3 impair host defense during lethal pneumonia caused by serotype 3 Streptococcus pneumoniae in mice. European journal of immunology. 2018;48(1):66-79.

175. Witzenrath M, Pache F, Lorenz D, Koppe U, Gutbier B, Tabeling C, et al. The NLRP3 inflammasome is differentially activated by pneumolysin variants and contributes to host defense in pneumococcal pneumonia. The Journal of Immunology. 2011;187(1):434-40.

176. Janko C, Munoz L, Chaurio R, Maueröder C, Berens C, Lauber K, et al. Navigation to the graveyard-induction of various pathways of necrosis and their classification by flow cytometry. Necrosis: Springer; 2013. p. 3-15.

177. Kong EF, Johnson JK, Jabra-Rizk MA. Community-associated methicillin-resistant Staphylococcus aureus: an enemy amidst us. PLoS pathogens. 2016;12(10):e1005837.

178. Kern WV. Management of Staphylococcus aureus bacteremia and endocarditis: progresses and challenges. Current opinion in infectious diseases. 2010;23(4):346-58.

179. Ibrahim F, Khan T, Pujalte GG. Bacterial skin infections. Primary Care: Clinics in Office Practice. 2015;42(4):485-99.

180. Mistry RD. Skin and soft tissue infections. Pediatric Clinics. 2013;60(5):1063-82.

181. Miller LS. Toll-like receptors in skin. Advances in dermatology. 2008;24:71.

182. Kobayashi SD, Malachowa N, DeLeo FR. Pathogenesis of Staphylococcus aureus abscesses. The American journal of pathology. 2015;185(6):1518-27.

183. Pasparakis M, Haase I, Nestle FO. Mechanisms regulating skin immunity and inflammation. Nature reviews immunology. 2014;14(5):289-301.

184. Bitschar K, Wolz C, Krismer B, Peschel A, Schittek B. Keratinocytes as sensors and central players in the immune defense against Staphylococcus aureus in the skin. Journal of dermatological science. 2017;87(3):215-20.

185. Brandt SL, Putnam NE, Cassat JE, Serezani CH. Innate Immunity to Staphylococcus aureus: Evolving Paradigms in Soft Tissue and Invasive Infections. The Journal of Immunology. 2018;200(12):3871-80.

186. Kobayashi SD, Malachowa N, Whitney AR, Braughton KR, Gardner DJ, Long D, et al. Comparative analysis of USA300 virulence determinants in a rabbit model of skin and soft tissue infection. Journal of Infectious Diseases. 2011;204(6):937-41. 
187. Kennedy AD, Wardenburg JB, Gardner DJ, Long D, Whitney AR, Braughton KR, et al. Targeting of alpha-hemolysin by active or passive immunization decreases severity of USA300 skin infection in a mouse model. The Journal of infectious diseases. 2010;202(7):1050-8.

188. Cheng AG, Kim HK, Burts ML, Krausz T, Schneewind O, Missiakas DM. Genetic requirements for Staphylococcus aureus abscess formation and persistence in host tissues. The FASEB Journal. 2009;23(10):3393-404.

189. Kielian T, Bearden ED, Baldwin AC, Esen N. IL-1 and TNF- $\alpha$ play a pivotal role in the host immune response in a mouse model of Staphylococcus aureus-induced experimental brain abscess. Journal of Neuropathology \& Experimental Neurology. 2004;63(4):381-96.

190. Aldrich A, Kielian T. Central nervous system fibrosis is associated with fibrocyte-like infiltrates. The American journal of pathology. 2011;179(6):2952-62.

191. Torroella-Kouri M, Silvera R, Rodriguez D, Caso R, Shatry A, Opiela S, et al. Identification of a subpopulation of macrophages in mammary tumor-bearing mice that are neither M1 nor M2 and are less differentiated. Cancer Res. 2009;69(11):4800-9.

192. Cassetta L, Cassol E, Poli G. Macrophage polarization in health and disease. ScientificWorldJournal. 2011;11:2391-402.

193. Biswas SK, Mantovani A. Orchestration of metabolism by macrophages. Cell Metab. 2012;15(4):432-7.

194. Hesse M, Modolell M, La Flamme AC, Schito M, Fuentes JM, Cheever AW, et al. Differential regulation of nitric oxide synthase- 2 and arginase- 1 by type 1/type 2 cytokines in vivo: granulomatous pathology is shaped by the pattern of L-arginine metabolism. The Journal of Immunology. 2001;167(11):6533-44.

195. Sica A, Bronte V. Altered macrophage differentiation and immune dysfunction in tumor development. The Journal of clinical investigation. 2007;117(5):1155-66.

196. Ferrante CJ, Leibovich SJ. Regulation of macrophage polarization and wound healing. Advances in wound care. 2012;1(1):10-6.

197. Thurlow LR, Joshi GS, Richardson AR. Peroxisome proliferator-activated receptor $\gamma$ is essential for the resolution of Staphylococcus aureus skin infections. Cell host \& microbe. 2018;24(2):261-70. e4.

198. Castleman MJ, Febbraio M, Hall PR. CD36 is essential for regulation of the host innate response to staphylococcus aureus $\alpha$-toxin-mediated dermonecrosis. The Journal of Immunology. 2015;195(5):2294-302.

199. Oh J, Riek AE, Weng S, Petty M, Kim D, Colonna M, et al. Endoplasmic reticulum stress controls M2 macrophage differentiation and foam cell formation. Journal of Biological Chemistry. 2012;287(15):11629-41.

200. Stuart LM, Deng J, Silver JM, Takahashi K, Tseng AA, Hennessy EJ, et al. Response to Staphylococcus aureus requires CD36-mediated phagocytosis triggered by the $\mathrm{COOH}$-terminal cytoplasmic domain. The Journal of cell biology. 2005;170(3):477-85.

201. Hoebe K, Georgel P, Rutschmann S, Du X, Mudd S, Crozat K, et al. CD36 is a sensor of diacylglycerides. Nature. 2005;433(7025):523-7.

202. Mehta A, Baltimore D. MicroRNAs as regulatory elements in immune system logic. Nature Reviews Immunology. 2016;16(5):279.

203. Jingjing Z, Nan Z, Wei W, Qinghe G, Weijuan W, Peng W, et al. MicroRNA-24 modulates Staphylococcus aureus-induced macrophage polarization by suppressing CHI3L1. Inflammation. 2017;40(3):995-1005.

204. Luoreng Z-M, Wang X-P, Mei C-G, Zan L-S. Comparison of microRNA profiles between bovine mammary glands infected with Staphylococcus aureus and Escherichia coli. International journal of biological sciences. 2018;14(1):87.

205. Tanaka K, Kim SE, Yano H, Matsumoto G, Ohuchida R, Ishikura Y, et al. MiR-142 is required for Staphylococcus aureus clearance at skin wound sites via small GTPase-mediated 
regulation of the neutrophil actin cytoskeleton. Journal of Investigative Dermatology. 2017;137(4):931-40.

206. Ramirez HA, Pastar I, Jozic I, Stojadinovic O, Stone RC, Ojeh N, et al. Staphylococcus aureus triggers induction of miR-15B-5P to diminish DNA repair and deregulate inflammatory response in diabetic foot ulcers. Journal of Investigative Dermatology. 2018;138(5):1187-96.

207. de Kerckhove M, Tanaka K, Umehara T, Okamoto M, Kanematsu S, Hayashi H, et al. Targeting miR-223 in neutrophils enhances the clearance of Staphylococcus aureus in infected wounds. EMBO Molecular Medicine. 2018;10(10).

208. Canfrán-Duque A, Rotllan N, Zhang X, Fernández-Fuertes M, Ramírez-Hidalgo C, Araldi E, et al. Macrophage deficiency of miR-21 promotes apoptosis, plaque necrosis, and vascular inflammation during atherogenesis. EMBO molecular medicine. 2017;9(9):1244-62.

209. Wang Z, Brandt S, Medeiros A, Wang S, Wu H, Dent A, et al. MicroRNA 21 is a homeostatic regulator of macrophage polarization and prevents prostaglandin E2-mediated M2 generation. PloS one. 2015;10(2).

210. Xue X, Qiu Y, Yang H-L. Immunoregulatory role of MicroRNA-21 in macrophages in response to bacillus calmette-guerin infection involves modulation of the TLR4/MyD88 signaling pathway. Cellular Physiology and Biochemistry. 2017;42(1):91-102.

211. Deguine J, Barton GM. MyD88: a central player in innate immune signaling. F1000prime reports. 2014;6.

212. Kawai T, Akira S. The role of pattern-recognition receptors in innate immunity: update on Toll-like receptors. Nature immunology. 2010;11(5):373.

213. Takeda K, Akira S, editors. TLR signaling pathways. Seminars in immunology; 2004: Elsevier.

214. Akira S, Takeda K, Kaisho T. Toll-like receptors: critical proteins linking innate and acquired immunity. Nature immunology. 2001;2(8):675-80.

215. Takeda K, Akira S. Toll receptors and pathogen resistance. Cellular microbiology. 2003;5(3):143-53.

216. Putnam NE, Fulbright LE, Curry JM, Ford CA, Petronglo JR, Hendrix AS, et al. MyD88 and IL-1R signaling drive antibacterial immunity and osteoclast-driven bone loss during Staphylococcus aureus osteomyelitis. PLoS pathogens. 2019;15(4):e1007744.

217. Takeuchi O, Hoshino K, Akira S. Cutting edge: TLR2-deficient and MyD88-deficient mice are highly susceptible to Staphylococcus aureus infection. The Journal of Immunology. 2000;165(10):5392-6.

218. Miller LS, O'Connell RM, Gutierrez MA, Pietras EM, Shahangian A, Gross CE, et al. MyD88 mediates neutrophil recruitment initiated by IL-1R but not TLR2 activation in immunity against Staphylococcus aureus. Immunity. 2006;24(1):79-91.

219. Plaut RD, Mocca CP, Prabhakara R, Merkel TJ, Stibitz S. Stably luminescent Staphylococcus aureus clinical strains for use in bioluminescent imaging. PloS one. 2013;8(3):e59232.

220. Becker RE, Berube BJ, Sampedro GR, DeDent AC, Wardenburg JB. Tissue-specific patterning of host innate immune responses by Staphylococcus aureus $\alpha$-toxin. Journal of innate immunity. 2014;6(5):619-31.

221. Johnston DG, Kearney J, Zasłona Z, Williams MA, O'Neill LA, Corr SC. MicroRNA21 limits uptake of Listeria monocytogenes by macrophages to reduce the intracellular niche and control infection. Frontiers in cellular and infection microbiology. 2017;7:201.

222. Hackett EE, Charles-Messance H, O'Leary SM, Gleeson LE, Muñoz-Wolf N, Case S, et al. Mycobacterium tuberculosis Limits Host Glycolysis and IL-1 $\beta$ by Restriction of PFK-M via MicroRNA-21. Cell Reports. 2020;30(1):124-36. e4.

223. Liu PT, Wheelwright M, Teles R, Komisopoulou E, Edfeldt K, Ferguson B, et al. MicroRNA-21 targets the vitamin D-dependent antimicrobial pathway in leprosy. Nature medicine. 2012;18(2):267. 
224. Podsiad A, Standiford TJ, Ballinger MN, Eakin R, Park P, Kunkel SL, et al. MicroRNA-155 regulates host immune response to postviral bacterial pneumonia via IL-23/IL17 pathway. American Journal of Physiology-Lung Cellular and Molecular Physiology. 2015;310(5):L465-L75.

225. Cheng AG, DeDent AC, Schneewind O, Missiakas D. A play in four acts: Staphylococcus aureus abscess formation. Trends in microbiology. 2011;19(5):225-32.

226. Mescher A. Macrophages and fibroblasts during inflammation and tissue repair in models of organ regeneration. 2017. March): 39 â.53.

227. Krzyszczyk P, Schloss R, Palmer A, Berthiaume F. The role of macrophages in acute and chronic wound healing and interventions to promote pro-wound healing phenotypes. Frontiers in physiology. 2018;9:419.

228. Mirza R, DiPietro LA, Koh TJ. Selective and specific macrophage ablation is detrimental to wound healing in mice. The American journal of pathology. 2009;175(6):245462.

229. Pennathur S, Pasichnyk K, Bahrami NM, Zeng L, Febbraio M, Yamaguchi I, et al. The macrophage phagocytic receptor CD36 promotes fibrogenic pathways on removal of apoptotic cells during chronic kidney injury. The American journal of pathology. 2015;185(8):2232-45.

230. Woo M-S, Yang J, Beltran C, Cho S. Cell surface CD36 protein in monocyte/macrophage contributes to phagocytosis during the resolution phase of ischemic stroke in mice. Journal of Biological Chemistry. 2016;291(45):23654-61.

231. Xu N, Bo Q, Shao R, Liang J, Zhai Y, Yang S, et al. Chitinase-3-Like-1 Promotes M2 Macrophage Differentiation and Induces Choroidal Neovascularization in Neovascular AgeRelated Macular Degeneration. Investigative ophthalmology \& visual science. 2019;60(14):4596-605.

232. Talreja D, Singh PK, Kumar A. In vivo role of TLR2 and MyD88 signaling in eliciting innate immune responses in staphylococcal endophthalmitis. Investigative ophthalmology \& visual science. 2015;56(3):1719-32.

233. Dilda F, Gioia G, Pisani L, Restelli L, Lecchi C, Albonico F, et al. Escherichia coli lipopolysaccharides and Staphylococcus aureus enterotoxin B differentially modulate inflammatory microRNAs in bovine monocytes. The Veterinary Journal. 2012;192(3):514-6.

234. Jin W, Ibeagha-Awemu EM, Liang G, Beaudoin F, Zhao X. Transcriptome microRNA profiling of bovine mammary epithelial cells challenged with Escherichia coli or Staphylococcus aureus bacteria reveals pathogen directed microRNA expression profiles. BMC genomics. 2014;15(1):181.

235. Sheedy FJ, Palsson-McDermott E, Hennessy EJ, Martin C, O'leary JJ, Ruan Q, et al. Negative regulation of TLR4 via targeting of the proinflammatory tumor suppressor PDCD4 by the microRNA miR-21. Nature immunology. 2010;11(2):141.

236. Melnik BC. MiR-21: an environmental driver of malignant melanoma? Journal of translational medicine. 2015;13(1):202.

237. Melo LM, Bragato JP, Venturin GL, Rebech GT, Costa SF, Garcia LE, et al. Induction of miR 21 impairs the anti-Leishmania response through inhibition of IL-12 in canine splenic leukocytes. PloS one. 2019;14(12).

238. Cui B, Liu W, Wang X, Chen Y, Du Q, Zhao X, et al. Brucella Omp25 upregulates miR-155, miR-21-5p, and miR-23b to inhibit interleukin-12 production via modulation of programmed death-1 signaling in human monocyte/macrophages. Frontiers in immunology. $2017 ; 8: 708$.

239. Chen Y, Chen J, Wang H, Shi J, Wu K, Liu S, et al. HCV-induced miR-21 contributes to evasion of host immune system by targeting MyD88 and IRAK1. PLoS pathogens. 2013;9(4). 
240. Miller LS, Pietras EM, Uricchio LH, Hirano K, Rao S, Lin H, et al. Inflammasomemediated production of IL- $1 \beta$ is required for neutrophil recruitment against Staphylococcus aureus in vivo. The Journal of Immunology. 2007;179(10):6933-42.

241. Aufiero B, Guo M, Young C, Duanmu Z, Talwar H, Lee HK, et al. Staphylococcus aureus induces the expression of tumor necrosis factor- $\alpha$ in primary human keratinocytes. International journal of dermatology. 2007;46(7):687-94.

242. Liu C, Ouyang W, Xia J, Sun X, Zhao L, Xu F. Tumor Necrosis Factor- $\alpha$ Is Required for Mast Cell-Mediated Host Immunity Against Cutaneous Staphylococcus aureus Infection. The Journal of infectious diseases. 2018;218(1):64-74.

243. Stenzel W, Dahm J, Sanchez-Ruiz M, Miletic H, Hermann M, Courts C, et al. Regulation of the inflammatory response to Staphylococcus aureus-induced brain abscess by interleukin-10. Journal of Neuropathology \& Experimental Neurology. 2005;64(12):1046-57.

244. Deckert M, Soltek S, Geginat G, Lütjen S, Montesinos-Rongen M, Hof H, et al. Endogenous interleukin-10 is required for prevention of a hyperinflammatory intracerebral immune response in Listeria monocytogenes meningoencephalitis. Infection and immunity. 2001;69(7):4561-71.

245. Rose WE, Eickhoff JC, Shukla SK, Pantrangi M, Rooijakkers S, Cosgrove SE, et al. Elevated serum interleukin-10 at time of hospital admission is predictive of mortality in patients with Staphylococcus aureus bacteremia. The Journal of infectious diseases. 2012;206(10):160411.

246. Leech JM, Lacey KA, Mulcahy ME, Medina E, McLoughlin RM. IL-10 plays opposing roles during Staphylococcus aureus systemic and localized infections. The Journal of Immunology. 2017;198(6):2352-65.

247. McCaig LF, McDonald LC, Mandal S, Jernigan DB. Staphylococcus aureus-associated skin and soft tissue infections in ambulatory care. Emerging infectious diseases. 2006;12(11):1715.

248. Zanotti S, Gibertini S, Curcio M, Savadori P, Pasanisi B, Morandi L, et al. Opposing roles of miR-21 and miR-29 in the progression of fibrosis in Duchenne muscular dystrophy. Biochimica et Biophysica Acta (BBA)-Molecular Basis of Disease. 2015;1852(7):1451-64.

249. Chau BN, Xin C, Hartner J, Ren S, Castano AP, Linn G, et al. MicroRNA-21 promotes fibrosis of the kidney by silencing metabolic pathways. Science translational medicine. 2012;4(121):121ra18-ra18.

250. Li C, Nguyen HT, Zhuang Y, Lin Y, Flemington EK, Guo W, et al. Post-transcriptional up-regulation of miR-21 by type I collagen. Molecular carcinogenesis. 2011;50(7):563-70.

251. Jafarinejad-Farsangi S, Gharibdoost F, Farazmand A, Kavosi H, Jamshidi A, Karimizadeh E, et al. MicroRNA-21 and microRNA-29a modulate the expression of collagen in dermal fibroblasts of patients with systemic sclerosis. Autoimmunity. 2019;52(3):108-16.

252. Parks BW, Black LL, Zimmerman KA, Metz AE, Steele C, Murphy-Ullrich JE, et al. CD36, but not G2A, modulates efferocytosis, inflammation, and fibrosis following bleomycininduced lung injury. Journal of lipid research. 2013;54(4):1114-23.

253. Stuart LM, Deng J, Silver JM, Takahashi K, Tseng AA, Hennessy EJ, et al. Response to Staphylococcus aureus requires CD36-mediated phagocytosis triggered by the $\mathrm{COOH}$-terminal cytoplasmic domain. J Cell Biol. 2005;170(3):477-85.

254. Feng J, Li A, Deng J, Yang Y, Dang L, Ye Y, et al. miR-21 attenuates lipopolysaccharide-induced lipid accumulation and inflammatory response: potential role in cerebrovascular disease. Lipids in health and disease. 2014;13(1):27.

255. Hanke ML, Angle A, Kielian T. MyD88-dependent signaling influences fibrosis and alternative macrophage activation during Staphylococcus aureus biofilm infection. PloS one. $2012 ; 7(8)$. 